Milene Moraes

A CONVERGÊNCIA POÉTICA DE MURILO MENDES

Universidade Federal de Minas Gerais

Faculdade de Letras

2012 


\section{Milene Moraes}

\section{A CONVERGÊNCIA POÉTICA DE MURILO MENDES}

Dissertação apresentada ao Programa de PósGraduação em Letras: Estudos Literários da Faculdade de Letras da Universidade Federal de Minas Gerais, como requisito parcial à obtenção do título de Mestre em Estudos Literários.

Área de concentração: Literatura Brasileira. Orientador (a): Dr. ${ }^{\text {a }}$ Claúdia Campos Soares

\section{Belo Horizonte}

\section{Faculdade de Letras da UFMG}


Para minha mãe, porque o amor tem nome. 


\section{AGRADECIMENTOS}

A toda a minha família e, em especial, à minha mãe, por tudo: sua força, dedicação e apoio que me permitiram chegar até aqui. E, sobretudo, pelo amor.

À minha orientadora, Claúdia, que me acolheu nesta universidade, pela confiança, generosidade e paciência com que conduziu este trabalho. E já que, como diz Riobaldo, muita coisa importante falta nome, receba o meu sincero muito obrigada!

Ao professor, pedra noventa, Dr. Duda Machado, da Universidade Federal de Ouro Preto, que viu e auxiliou desde o primeiro momento o nascimento deste projeto. Só tenho a agradecer-lhe pelo incentivo e pelo convívio amigável.

Ao professor e amigo, Éclair, por sua amizade generosa que tanta alegria me concede. Pela vida, pela escrita, pela vida escrita e dividida com a beleza que será convulsiva ou não será! Ah, e pela totalidade, porque é ela que interessa toujours e tous les jours!

Aos membros da banca, professor Dr $^{\circ}$ Murilo Marcondes de Moura e professor $\operatorname{Dr}^{\circ}$ Sérgio Alcides Pereira do Amaral pela gentileza em aceitarem o convite para colaborar no aperfeiçoamento deste trabalho.

O meu muito obrigada, também, às queridas amigas Elzira, Sabrina e Raquel que dividiram comigo durante o processo de escrita não só a letra, o pão, a família, mas a vida! E ser amigo é dividir a vida!

Às queridas Maria Emília e Priscila pela amizade fiel, pelo carinho e o apoio de sempre! Aos amigos deste mestrado, em especial, aos da disciplina "rima e solução" e, sobretudo, à querida Lídia que sentou-se comigo à beira do antiuniverso da poesia. Pelo companheirismo e pelo presente desta amizade que se construiu entre nós. Comigo e contigo, a poesia! Sempre!

Por fim, ao Murilo, que todos os dias durante estes dois anos me emprestou sua musa e me ensinou a rejeitar a dimensão comum do mundo! 
Sempre, em todos os tempos, a poesia corrigiu a crítica.

Murilo Mendes 


\section{RESUMO}

Esta dissertação concentra-se no estudo da recepção da obra poética de Murilo Mendes, já que esta é fortemente marcada por uma série de divergências entre seus principais críticos. Estas divergências situam-se bem além da tradicional divisão da obra do poeta em duas fases, pois alguns críticos atribuem maior valor poético a uma destas fases em especial. Em nossa análise da recepção crítica procuramos demonstrar a não pertinência desta divisão rígida em termos de qualidade poética efetuada pela crítica. Assim, propomos demonstrar a existência de uma interligação entre estas possíveis "fases" murilianas, seguindo a perspectiva postulada por Sebastião Uchôa Leite (2003) e para tal analisamos, através da elaboração de um inventário, alguns dos principais vetores da poesia muriliana como: o humor, a presença do feminino, a recorrência da questão do olhar/visualidade, a dimensão metalinguística. Este inventário foi realizado através da consideração do último livro muriliano, Convergência, por acreditarmos que ele representa um momento especial na trajetória de Murilo Mendes.

Palavras-chave: recepção crítica, poesia brasileira, Murilo Mendes. 


\section{RÉSUMÉ}

Cette dissertation de maîtrise se propose d'étudier la réception critique de Murilo Mendes et sa poésie. La réception de Murilo est fort marquée par une série de désaccords entre ses principaux critiques. Ces différences se situent bien au-delà de la division traditionnelle du travail du poète en phases différentes parce que quelques critiques attribuent plus de valeur poétique à l'une de ces phases en particulier. Notre analyse de cette sorte de réception a cherché à démontrer la non-pertinence de cette division rigide en termes de qualité poétique faite par la critique. Ainsi, nous nous proposons de démontrer l'existence d'un lien possible entre ces «phases» muriliennes, suivant l'approche postulée par Sebastião Uchôa Leite (2003), en analysant pour cela de par la mise en place d'un inventaire quelques-uns des principaux vecteurs de la poésie murilienne tels quels: l'humour, la dimension métalinguistique, la voix multiple du poète, la présence des femmes et la récurrence de la question du regard / visualité. Cet inventaire a été effectué en tenant compte du dernier livre murilien, Convergência, parce que nous croyons qu'il représente un moment privilégié dans la trajectoire de Murilo Mendes.

Mots-clés : réception critique, poésie brésilienne, Murilo Mendes. 


\section{SUMÁRIO}

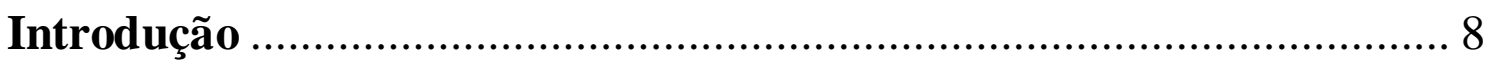

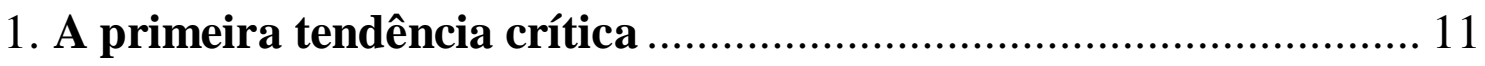

1.1A perspectiva de Haroldo de Campos ........................................... 11

1.2 A perspectiva de Luiz Costa Lima............................................... 18

1.3 A perspectiva de Alfredo Bosi .................................................... 21

1.4 A perspectiva de João Alexandre Barbosa .................................... 27

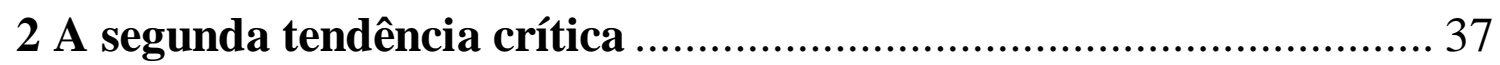

2.1 A perspectiva de Sebastião Uchôa Leite ......................................... 55

3 A convergência poética de Murilo Mendes …................................. 60

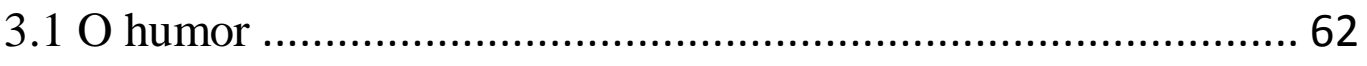

3.2 A metalinguagem/a autorreflexividade .................................. 78

3.3 A voz múltipla de Murilo Mendes ............................................ 84

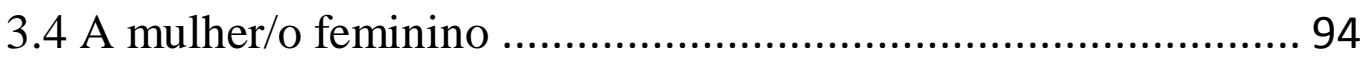

3.5 A imagem/a visualidade ..................................................... 103

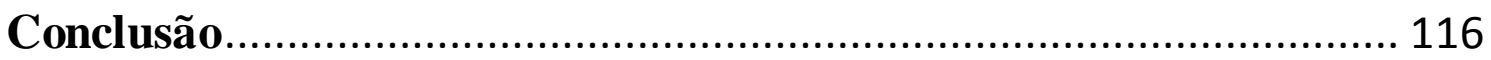

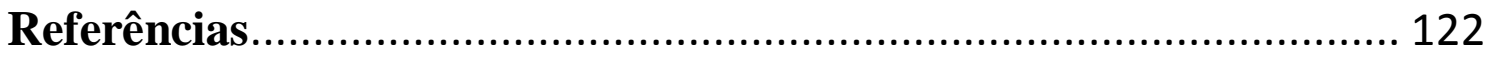




\section{INTRODUÇÃO}

Ao iniciar nossos primeiros estudos sobre a obra de Murilo Mendes percebemos que alguns críticos valorizavam uma parte de sua poesia e consideravam de menor valor uma outra parte. Esta constatação nos despertou interesse e nos moveu a investigar os motivos desta discrepância na valorização da obra de um mesmo poeta. Ao mesmo tempo em que íamos lendo e tentando entender porque isso ocorria, embrenhávamos cada vez mais na poesia de Murilo, nos deslumbrando com seus versos dotados de tamanha profundidade poética e visionária.

Percebemos também que, não obstante a importância atribuída desde o início à poesia de Murilo Mendes, que estreou em livro em 1930 com Poemas, a recepção crítica de sua obra podia ser considerada um pouco tardia se comparada aos estudos críticos dedicados a outros poetas modernistas como Manuel Bandeira, Carlos Drummond de Andrade e João Cabral de Melo Neto ${ }^{1}$. Esta demora no surgimento de novas interpretações não sucedeu, como a crítica acabou por reconhecer, por desmerecimento e pode ter ocorrido em virtude da posição desconcertante que Murilo sempre ocupou no panorama da literatura brasileira ou mesmo à própria ausência do poeta do país, já que a partir de 1957 Murilo fixou-se definitivamente na Itália, retornando ao Brasil apenas esporadicamente. Entretanto, no decorrer de nossa investigação acerca da recepção crítica de Murilo, notava, também, que este estado de coisas estava se transformando, pois aos poucos fomos nos deparando com novos textos críticos sobre o poeta e sua obra e víamos que esse corpus já podia ser considerado bem substancial.

A partir dele realizamos um recorte específico do qual selecionamos algumas das interpretações mais recentes realizadas por alguns dos principais representantes de nossa crítica literária ${ }^{2}$. Desse modo, pudemos extrair alguns dados interessantes e traçar um breve mapeamento do estado atual da recepção crítica da poesia de Murilo Mendes. A partir deste trabalho instrumental, extraímos certas divergências e convergências

\footnotetext{
${ }^{1}$ Exceção seja feita a uma das primeiras críticas realizadas sobre a poesia muriliana, a de Mário de Andrade, que já em 1931 realizou uma crítica ao primeiro livro de Murilo lançado no ano anterior. No artigo "A poesia em 30", o crítico destacou e comentou, além do livro muriliano, outros três importantes livros de poemas lançados no mesmo ano: Alguma Poesia de Carlos Drummond de Andrade, Libertinagem de Manuel Bandeira e Pássaro Cego de Augusto Frederico Schmidt.

${ }^{2}$ É devido a isso que não incluímos nesse "corpus" alguns críticos que também desenvolveram interpretações importantes sobre a poesia de Murilo como os trabalhos pioneiros de Otto Maria Carpeaux, Mário de Andrade, Álvaro Lins e Antonio Candido.
} 
entre os críticos envolvidos, fato que nos possibilitou o estabelecimento de duas tendências críticas nessa recepção.

A primeira tendência está representada pelas vozes de Haroldo de Campos, Alfredo Bosi, João Alexandre Barbosa e Luiz Costa Lima e foi em seu interior que encontramos aquele incômodo relatado acima. Isso ocorreu porque estes críticos estabeleceram uma divisão da poesia muriliana, de natureza qualitativa, atribuindo ao que eles consideraram como "segunda fase" dessa poesia, uma qualidade poética superior em relação à dita "primeira fase". Sumariamente, segundo essa tendência, haveria, na obra de Murilo, uma fase surrealista mística/cristã, caracterizada, sobretudo, pela imagética de teor altamente onírico e/ou místico/cristão; e outra mais voltada para a materialidade e a concisão da linguagem. Para os críticos que compõem essa que estamos chamando de primeira tendência crítica da recepção de Murilo, teria havido, na trajetória do poeta, um processo evolutivo de aprimoramento que encontraria sua realização plena na dita segunda fase de sua obra.

Cabe dizer que, embora tenhamos reunido esses críticos numa tendência específica de abordagem da obra de Murilo Mendes, cada um deles possui sua própria visão teórica como poderemos notar mais adiante. Devido a isso, apesar da convergência inicial de interpretação, percebemos que ocorria uma série de divergências significativas no interior desta tendência e que diziam respeito a várias questões importantes da poesia de Murilo. A principal divergência está relacionada ao livro que indicaria para cada um desses críticos a mudança de fase, ou seja, o livro que marcaria o momento em que a poesia de Murilo amadureceu. Para representar este momento, cada crítico elegeu um livro diferente, a exceção é João Alexandre Barbosa que não elegeu nenhum livro em especial.

A análise dos pressupostos e argumentos das interpretações desta primeira tendência crítica, bem como, a consideração e avaliação das escolhas divergentes do livro ápice da maturidade poética de Murilo foram realizadas por nós em nosso primeiro capítulo, "A primeira tendência crítica". Assim, neste primeiro capítulo, buscamos olhar criticamente para os argumentos que sustentam as interpretações desses críticos a fim de perceber em quais concepções estético-ideológicas eles estavam fundamentados.

Um segundo conjunto de críticos contesta a cisão da obra de Murilo entre uma primeira e uma segunda fase. Para esses, a obra muriliana seria fundamentalmente heterogênea e, portanto, seria inadequado à forma como se constitui enquadrá-la em 
segmentações rígidas que acabam por reduzir sua complexidade. Dentre os críticos que partilham desta perspectiva encontram-se: Irene Miranda Franco, Joana Matos Frias, Júlio Castañon Guimarães, Laís Corrêa de Araújo, Murilo Marcondes de Moura e Sebastião Uchôa Leite.

Nosso trabalho se identificou, desde o princípio, com a visão apresentada por essa segunda tendência sobre a impossibilidade de se definir e se dividir a poesia de Murilo em termos rígidos. A nosso ver, os argumentos desta segunda tendência resistem mais quando do cotejo com a obra poética de Murilo Mendes, ao passo que com os da primeira tendência isso não ocorre, como pretendemos demonstrar neste trabalho.

Em nosso segundo capítulo, “A segunda tendência crítica e a perspectiva de Sebastião Uchôa Leite", buscamos, em primeiro lugar, analisar a perspectiva desta tendência em contraste com a da primeira, demonstrando os argumentos dos críticos da segunda tendência em relação a não pertinência desta cisão da poesia muriliana. Em segundo lugar, analisamos o ponto de vista de Sebastião Uchôa Leite (2003) de que esta divisão ocultaria um aspecto decisivo da poesia muriliana: a existência de uma espécie de "diálogo intertextual" em sua obra como um todo. Para Uchôa Leite, no último livro de poemas de Murilo lançado em vida, Convergência, (1970) repercutem ecos da intensa aventura poética iniciada com Poemas em 1930.

Levando-se em conta o momento especial na trajetória muriliana representado por Convergência e assumindo como referencial crítico-teórico a perspectiva de Uchôa Leite, dedicamos nosso terceiro e último capítulo, "A convergência poética de Murilo Mendes", à elaboração de um pequeno inventário, de alguns das principais questões que envolveram a poesia muriliana, como o humor; a presença do feminino/mulher; a recorrência da questão do olhar/visualidade; a dimensão metalingüística/autorreflexiva; a voz múltipla da poesia muriliana; o surrealismo e o aspecto religioso de sua poesia. Esperamos demonstrar na discussão desses temas e procedimentos como, apesar das mudanças e transformações ocorridas em sua obra ao longo do tempo, estes referenciais persistiram, pois se constituem numa espécie de base/estrutura poética com a qual o poeta edificou sua obra.

Deste modo, a escolha do título Convergência para esse livro é muito significativa e com ela Murilo já nos acenava para a possibilidade de reler, através deste livro, toda a sua trajetória, bem como, o alcance de seu projeto poético. 


\section{A PRIMEIRA TENDÊNCIA CRÍTICA}

Neste capítulo analisaremos a perspectiva da primeira tendência crítica, que, conforme já mencionamos, é composta pelos seguintes críticos: Haroldo de Campos, Alfredo Bosi, João Alexandre Barbosa e Luiz Costa Lima. Essa primeira tendência estabelece a divisão da obra poética de Murilo Mendes em duas fases, atribuindo uma evolução qualitativa à segunda fase. A primeira seria a fase surrealista mística/cristã, caracterizada, sobretudo, pela imagética de teor altamente onírico e/ou místico/cristão; e a segunda, mais voltada para a materialidade e a concisão da linguagem.

Entretanto, como já dissemos, apesar dessa convergência inicial entre eles, ocorre, em suas interpretações, uma série de divergências significativas. A principal divergência, que será vista neste capítulo, está relacionada ao livro que indicaria o momento dessa evolução qualitativa, pois neste ponto, cada crítico elege um livro diferente para marcar o que eles consideram o ápice poético de Murilo. Exceção seja feita a João Alexandre Barbosa, que não elege nenhum livro em especial. Essa divergência será discutida mais adiante ainda neste capítulo.

Analisando atentamente essa primeira tendência crítica, percebe-se em seu interior uma espécie de subdivisão que diz respeito ao próprio modo como estes críticos expressam seus pontos de vista sobre a obra muriliana. Assim, Luiz Costa Lima e Haroldo de Campos possuem pontos de vista mais enfáticos enquanto as perspectivas de Alfredo Bosi e João Alexandre Barbosa mostram-se um pouco menos rígidas.

Esta diferença, aparentemente apenas de estilo de uma posição mais rígida para outra menos inflexível na defesa de suas opiniões, ultrapassa esta barreira e traz implicações profundas para as análises de Haroldo de Campos, Luiz Costa Lima, Alfredo Bosi e João Alexandre Barbosa, que discutiremos a partir de agora.

\subsection{A perspectiva de Haroldo de Campos}

Principalmente no que diz respeito à perspectiva de Haroldo de Campos, pode-se dizer que ela confirma a observação efetuada por críticos da segunda tendência, como Murilo Marcondes de Moura (1995) e Sebastião Uchôa Leite (2003), por exemplo, de 
que a escolha pela "segunda fase" da poesia muriliana certificaria e asseguraria, na verdade, a opção por certo tipo de poética. Nas palavras de Moura,

\begin{abstract}
a sua [de Murilo Mendes] obra integral foi submetida a um corte drástico: um antes discutível e um depois elogiável. Na verdade, essa leitura, procurando integrar a obra inicial à obra final, nos termos de evolução linear do poeta, mostrou-se essencialmente desagregadora; muito comprometida com a dimensão construtivista da linguagem poética, então predominante, ela restringiu-se, voluntariamente ou não, a avaliar os primeiros livros do autor como preparatórios para uma poesia mais bem realizada. (MOURA, 1995, p. 57)
\end{abstract}

No caso de Haroldo de Campos, que é um dos idealizadores e porta-vozes da Poesia Concreta, torna-se clara a sua preferência, na consideração da poesia de Murilo, pela "segunda fase", que é caracterizada por ele como possuidora de uma concretude de linguagem e um rigor construtivista na criação. Não por acaso, essas características estão bem próximas das diretrizes e concepções concretistas apregoadas por ele e por outros membros do grupo, como o seu irmão, Augusto de Campos, e o poeta Décio Pignatari.

O texto de Haroldo que constitui parte de nosso corpus intitula-se "Murilo e o Mundo Substantivo" e está presente em seu livro Metalinguagem e Outras Metas, coletânea de textos críticos que, em sua maioria, foram veiculados no Suplemento Literário do jornal $O$ Estado de São Paulo nos anos 60. Um ponto interessante de se notar neste livro de Haroldo é a existência de um prefácio no qual o autor apresenta os textos da coletânea ao mesmo tempo em que nos oferece a sua concepção de crítica literária. No prefácio do livro, o crítico afirma que, dos trabalhos ali reunidos, dois são de ordem puramente teórica e metodológica e os demais, nos quais se inclui a análise de Murilo, "passam da teoria à prática, isto é, versam problemas concretos da poesia e da prosa brasileira contemporânea" (1970, p. 7). O que se depreende dessa declarada "passagem da teoria à pratica" é que o interesse do autor é, de fato, tratar de questões emblemáticas para os próprios poetas concretos. Haroldo chega a afirmar que o denominador comum temático destas análises é a obra de invenção, aquelas que rompem com as concepções artísticas de seu tempo e que, muitas vezes, só puderam ser apreciadas por gerações futuras, pois: "é especialmente na área de contributo de invenção de uma obra (...) que se testa a sintonia da metalinguagem com o seu tempo e 
com os textos em que esse tempo está mais vivo e efetivamente presente (aqueles, inclusive, em que já se engendra o futuro )" $(1970, \text { p.7) })^{3}$.

Além do atributo da invenção, Haroldo destaca outro critério para que uma obra possa ser considerada como verdadeira obra de arte: a "originalidade". Esta é verificada por ele em obras paradigmáticas que, em sua visão, romperam com concepções préestabelecidas ou mesmo já ultrapassadas sobre o que seria literatura e, por extensão, poesia.

Neste ponto, convém indicar que esses valores defendidos por Haroldo são os mesmos eleitos por Erza Pound em seus ensaios e textos críticos, como nos informa Leyla Perrone-Moisés em Altas Literaturas (1998). A autora também destaca que a própria lista do cânone haroldiano/concretista é tributária do paideuma poundiano. Em seu livro, Leyla discute e analisa o nascimento, no século XX, dessa espécie de contracrítica praticada pelos poetas e escritores em oposição e devido à insatisfação com a crítica e historiografia tradicionais. Além da crítica praticada por Haroldo de Campos, a autora analisa também a obra crítica de T. S. Eliot, Ezra Pound, ao qual já aludimos, Octavio Paz, Jorge Luis Borges, Italo Calvino, Michel Butor e Philippe Sollers

Segundo a autora, essa nova crítica é necessariamente parcial, como, de resto, qualquer outra. No caso, isso ocorre especificamente porque a crítica desses autores está a serviço da prática de cada um deles. A própria escolha das obras do passado nesses escritores-críticos é, segundo Leyla, a expressão de um julgamento, pois: “[a] o escolher falar de certos escritores do passado e não de outros, os escritores-críticos efetuam um primeiro julgamento. Assim fazendo, cada um deles estabelece sua própria tradição e, de certa maneira, reescreve a história literária.” (PERRONE-MOISÉS, 1998, p.11)

Neste ponto, recordamos uma observação bem semelhante à de Leyla, mas realizada pelo crítico alemão Michael Hamburger em A Verdade da Poesia (2007) quando comenta a respeito da crítica literária praticada por Erza Pound. Para Hamburger, a crítica de Pound tem pouco sentido exceto em relação à sua própria obra, já que o poeta "não tem paciência com nada que não seja grão para o seu moinho" (HAMBURGUER, 2007, p.173). É assim que Hamburguer indica que, mesmo quando existem fatos e circunstâncias que contradizem a crítica de Pound, o poeta salta sobre eles e os ignora violando substratos históricos de sentido simplesmente para que o objeto, autor ou obra, lhe sirva de exemplo e/ou provas.

\footnotetext{
${ }^{3}$ Grifo nosso.
} 
O crítico alemão nos chama a atenção para um dado extremamente importante na crítica literária, qual seja, a abertura para se compreender a alteridade. Hamburger indica isso ao comentar que, já que estes poetas que realizam a crítica de poesia possuem a inestimável vantagem de saber do que estão falando, justamente por isso eles deveriam ter certa disposição para compreender o que lhes é distinto. Mas a contestação, seja de si mesmo ou de seu sistema de valores, parece ser algo de difícil alcance para a crítica literária em geral e não só para aquela pratica por poetas e escritores, já que, como afirma Leyla Perrone-Moisés (1998), os juízos estéticos só podem pretender a uma objetividade autenticada por uma subjetividade.

Leyla ainda realiza outro apontamento interessante ao indicar o fato de que cada escritor ou poeta-crítico estabelece, por meio de sua prática, a sua própria tradição reescrevendo, assim, a história literária. Isso é bem nítido no caso de Haroldo e nos outros poetas-críticos concretistas também, pois mostra-se evidente que, os participantes do movimento se empenharam na busca de construir uma tradição que validasse suas prerrogativas e teorias. Nesse sentido, eles reescreveram a história literária colocando-se como herdeiros dessa tradição por eles erigida, uma verdadeira "tradição da ruptura" já que, nela, encontramos escritores e poetas que romperam ou ao menos manifestaram sua discordância em relação não só ao modo de produção poético-literária de seu tempo, mas também, com o meio no qual viviam.

É neste sentido que encontramos o empenho de recuperação efetuado pelos poetas-críticos concretistas de autores até então esquecidos na história de nossa literatura como Sousândrade e Kilkerry. Deve-se ainda a esse impulso a revisitação de poetas e escritores ligados ao movimento modernista representada, sobretudo, pela revalorização da obra de Oswald de Andrade, figura polêmica que, embora não estivesse tão distante no tempo, também andava esquecida em nossas letras.

Pode-se dizer que os poetas concretistas erigiram sua tradição e seus cânones não só por meio de suas atuações como críticos literários, mas também através de sua prática tradutória. Neste campo, particularmente, a atuação dos concretos representou uma das grandes contribuições para o público leitor brasileiro nos últimos tempos ao tornar acessível uma série de poetas e escritores até então inéditos em nosso meio. Assim, vemos que a escolha dos autores que os poetas concretistas traduziram também indica que, para eles, a tradução se apresentavacomo uma forma de (re) leitura dessa tradição e dos cânones que eles instauraram, uma (re) leitura ativa e crítica no sentido 
que a toma, por exemplo, Italo Calvino ao afirmar que "traduzir é o verdadeiro modo de ler um texto",4.

É na obra desses precursores revisitados, portanto, que os poetas concretistas foram buscar um conjunto de técnicas e procedimentos com o intuito de edificar um novo tipo de concepção poética, em contraponto à crise do verso que se abatera, de acordo com a sua perspectiva sobre a poesia de seu tempo. Em reação a esse momento de "desgaste", os poetas concretos propuseram um novo tipo de poesia na qual os elementos verbais, sonoros e visuais deveriam ser trabalhados em todas as suas potencialidades. Dentre as técnicas e procedimentos utilizados por eles podemos citar o elevado destaque concedido à sonoridade, a valorização do espaço como elemento estruturador do poema, a disposição das palavras na página e a abolição da sintaxe.

Depois desta breve, porém, acreditamos, necessária, digressão, voltemos ao texto de Haroldo sobre a poesia muriliana. Em seu título, o crítico se valeu de uma citação do próprio Murilo, qual seja, o aforismo 371 do livro O Discípulo de Emaús, que diz "passaremos do mundo adjetivo para o mundo substantivo". Haroldo toma esse aforismo como verdadeiro motivo para sua argumentação, pois, segundo ele, esta ideia valeria por todo um programa/projeto estético que fundamentaria a obra muriliana e que atingiria seu auge em Tempo Espanhol (1959). A partir de então, o crítico repassa a trajetória de Murilo até o livro citado, que será objeto de sua análise. Seu objetivo é demonstrar como o itinerário poético muriliano foi um longo esforço no sentido de transformar em prática essa afirmação teórica presente no aforismo de onde extraiu o título de seu estudo.

Haroldo chega a elaborar um inventário vocabular das palavras utilizadas em Tempo Espanhol - à maneira do método estilístico de Pierre Giraud ${ }^{5}$ - que, semanticamente, estariam ligadas à idéia de concretude e rigor. Ao indicar essa recorrência, Haroldo menciona que ela seria um dos aspectos microestéticos do livro e atestaria uma "obsessão do concreto". A ideia principal do crítico é o fato de que a poesia de Murilo teria se encaminhado cada vez mais para um mundo substantivo, como já aludido, ou seja, para uma poesia cada vez mais rigorosa. Em suas palavras: "poesia magra e dura, sem nenhuma concessão ao sentimentalismo dos melancólicos escudeiros da poesia-liricizante, da poesia-Gemüt" (CAMPOS, 1970, p. 58).

\footnotetext{
4 "Tradurre è il vero modo di leggere un testo" 4 foi uma conferência proferida por Calvino num congresso em Roma no dia 04 de junho de 1982. Aqui nos baseamos na tradução efetuada por Andréia Guerini e Tânia Mara Moysés, publicada no Suplemento Literário de Minas Gerais, março/abril/2011.

${ }^{5}$ Método descrito na obra Les Caractères Statistiques du Vocabulaire, de 1954.
} 
Entretanto, a simples enumeração de certas palavras, ainda que estejam ligadas semanticamente à principal ideia que se advoga, não garante o fato de que a poesia muriliana possa ser considerada como essa poesia "magra" e "dura" aludida por Haroldo, nem, tampouco, garante a possibilidade de que esta poesia possa ser considerada como o melhor momento na trajetória poética de Murilo Mendes.

Por isso, neste ponto, convém destacar que, a nosso ver, essa obsessão do concreto estaria no âmbito da própria crítica de Haroldo de Campos, pois é evidente que o crítico passa a analisar Tempo Espanhol numa tentativa de aproximação de Murilo à poesia concreta. Haroldo realiza outros apontamentos formais, como, por exemplo, a contenção da diversificação léxica da poesia anterior de Murilo $^{6}$ que teria levado o poeta a exercer e construir sua imagética contrastante dentro de uma linguagem voluntariamente reduzida.

O próprio Haroldo sabia que a sua crítica e a dos demais poetas-críticos concretistas corria o perigo de ser vista como mero partidarismo e que, na verdade, se poderia afirmar que seriam a poesia e a teoria concretas que teriam se embebido no vasto repertório de inovações empreendidas por poetas e ficcionistas tanto nacionais quanto internacionais. Atento a esta possibilidade e numa espécie de autodefesa, em seu artigo "Drummond, Mestre de Coisas" 7 , no qual analisa o livro Lição de Coisas (1962) de Carlos Drummond de Andrade, ao dissertar sobre a total inserção do livro na problemática brasileira/internacional da poesia de vanguarda, Haroldo assevera que em sua análise não se está querendo "fazer qualquer miúda reivindicação de possíveis áreas de influência ou contágio, pois antes, no caso, se poderia argumentar que, ao contrário, foi a poesia concreta que assumiu as consequências de certa linha da poemática drummondiana" (CAMPOS, 1970, p. 40).

É óbvio que não podemos ignorar a ligação de Murilo com o concretismo e, mais precisamente, em seu último livro, Convergência (1970). Ele incorporou em seus poemas algumas das técnicas que os concretistas revitalizaram e colocaram em circulação na poesia brasileira. Além disso, Murilo publicou alguns poemas deste livro no órgão porta-voz da poesia concreta, a revista Invenção ${ }^{8}$. Entretanto, esta possível influência pode ser relativizada sob diversos aspectos. Em nosso entender, essa contaminação se faria notar, sobretudo, devido à incorporação de todo um repertório de

\footnotetext{
${ }^{6}$ Fato também verificado por Alfredo Bosi (2004), como veremos mais adiante.

${ }^{7}$ Texto que também consta do volume Metalinguagem, já citado.

${ }^{8}$ Murilo publicou alguns poemas na edição de número 5 da revista Invenção, volume que abrangeu o período de novembro de 1966 a janeiro de 1967.
} 
procedimentos e técnicas tidas como concretistas, mas que, por sua vez, como vimos, os próprios concretos tomaram de empréstimos a diversos escritores e poetas modernos que constituíram o seu cânone. Voltaremos a essa questão da influência ou não do concretismo em Murilo em nosso terceiro capítulo quando formos analisar Convergência.

Como foi dito, para Haroldo, o rigor e a substantivação concreta da poesia de Murilo encontrariam seu ápice em Tempo Espanhol, último livro de Murilo publicado até 1963, data da primeira publicação do texto de Haroldo. Ao longo de seu texto, o crítico expõe e indica diversas vezes os motivos da sua escolha por esse livro como o mais representativo da trajetória de Murilo. Apesar disso, Haroldo chega a reconhecer que a reviravolta empreendida nesse volume já havia sido iniciada no livro anterior, a saber, Siciliana ${ }^{9}$ :

Convém registrar nessa esteira, que, em Siciliana (1954-1955), livro imediatamente anterior a Tempo Espanhol, a linguagem muriliana já é submetida a um primeiro impacto telúrico de rigor, como que ciliciada pela dura paisagem geográfica e humana da Itália meridional (...) (CAMPOS, 1970, p. 61).

Haroldo também menciona a existência na poesia de Murilo de uma certa dissonância no campo da imagem que ocorreria devido à aproximação de elementos contrastantes que, unidos, proporcionariam uma tensão e ilogicidade. Para o crítico concretista, essa dissonância já era uma característica das obras anteriores de Murilo e teria se intensificado em Poesia-Liberdade (1947), que contém poemas escritos de 1943 a 1945 marcados pelo espanto da Segunda Guerra Mundial que então ocorria.

Haroldo aponta o fato de que esta dissonância da poesia muriliana pode ser aproximada da discordia concors do Barroco. Entretanto, a nosso ver, o cultivo dessa dissonância imagética só foi possível na poesia de Murilo devido à absorção de alguns elementos do Surrealismo. Nas bases do movimento francês o poeta buscou os meios e as técnicas utilizadas para alcançar esses resultados, notadamente as técnicas de caráter combinatório $^{10}$. Num claro aproveitamento da definição de imagem realizada pelo poeta francês Pierre Reverdy ${ }^{11}$, o surrealismo institui a imagem poética, principalmente

\footnotetext{
${ }^{9}$ Este livro, Siciliana (1959), como veremos mais adiante, é tido por Luiz Costa Lima como o ponto de chegada da evolução qualitativa da poesia de Murilo Mendes.

${ }^{10}$ Murilo Marcondes de Moura analisa a utilização destas técnicas por parte de Murilo, o que se traduziria "na valorização da imagem e no impulso erótico e lúdico de combinar coisas díspares, com a 'atmosfera de mistério' que tal acoplamento era capaz de suscitar". (MOURA, 1995, p. 192).

11“"A imagem é uma criação pura do espírito. Ela não pode nascer de uma comparação, mas da aproximação de duas realidades mais ou menos distantes. Quanto mais as relações das duas realidades
} 
aquelas construídas sob um grau de arbitrariedade mais elevado, como um dos aspectos mais eminentes da poesia. Assim, fica claro que a discordia concors é alcançada na poesia de Murilo, em boa parte, pelo emprego da extração e da assimilação das técnicas combinatórias oriundas do surrealismo. Se nossa visão estiver correta, o argumento de Haroldo além de claramente parcial, apresenta incoerências e contradições ${ }^{12}$.

\subsection{A perspectiva de Luiz Costa Lima}

O texto de Costa Lima que integra o nosso corpus de interpretações intitula-se "Tríptico sobre Murilo Mendes" e está estruturado em três partes: a) Murilo Mendes: da dispersão à intensidade; b) Murilo Mendes em seu começo; c) $O$ agônico na abertura de Contemplação. Percebe-se que, na verdade, são três análises que vieram à luz separadamente e que foram reunidas num único texto publicado em Intervenções (2002). Logo no começo da primeira parte, o crítico expõe os seus dois principais objetivos na análise que se principia: "nossa tarefa visará mostrar (a) como se manifesta e explica a demora de encontro de sua voz própria e (b) como se afirma o poeta maior." (2002, p. 72).

Com essa afirmação, da demora de Murilo em encontrar sua voz, o crítico se alia a outros, como Haroldo, que também mencionou algo semelhante tornando este apontamento uma espécie de lugar-comum na recepção crítica de Murilo. Entretanto, em relação ao segundo objetivo, Costa Lima expressa de maneira bem explícita que, para ele, há uma diferença qualitativa na obra de Murilo, pois ao dizer que Murilo demora a e se afirmar como "poeta maior" pressupõe que existiu um "poeta menor" nessa trajetória. Deste modo, o crítico deixa bem clara a sua posição ao manifestar, em termos enfáticos, a existência de uma mudança qualitativa na poesia muriliana.

aproximadas forem longínquas, mais a imagem será forte - mais ela terá poder emotivo e realidade poética.” Pierre Reverdy apud Murilo Marcondes de Moura, 1995, p. 19.

${ }^{12}$ Essa referência ao Barroco na crítica de Haroldo relaciona-se, também, com o lugar e a importância desse movimento para os poetas concretistas que o viam como uma estação singular de nossas letras devido ao seu caráter metalinguístico, lúdico e autoreferencial. Neste sentido, é famoso o ensaio de Haroldo "O sequestro do Barroco na formação da literatura brasileira: o caso Gregório de Matos" (1989) no qual o crítico analisa a obra do poeta baiano e se posiciona contra a perspectiva de Antonio Candido que havia excluído o movimento de seu livro Formação da Literatura Brasileira (1959) por considerá-lo apenas uma manifestação literária isolada que não influiu em nossa história literária. 
Assim como Haroldo, Luiz Costa Lima também vê a presença da discordia concors na poesia muriliana, inclusive menciona que o primeiro a constatar isso foi Haroldo de Campos, bem como concorda com o poeta-crítico que a utilização recorrente deste efeito contribui para a intensificação da dissonância imagética. Costa Lima ressalta ainda que a dissonância imagética ainda é intensificada devido à inclinação religiosa de Murilo pelo cristianismo, já que este, para o crítico não só nutre a angústia do poeta, mas também, estimula a sua poesia.

$\mathrm{Na}$ ótica de Costa Lima, que tanto a pretensa demora em encontrar-se quanto a sua inerente multiplicidade foram prejudiciais para Murilo, pois enquanto o poeta passava por este processo, atrasava-se em desfrutar de sua maturidade e de sua verdadeira voz poética. Para o crítico, embora esta maturidade já se manifestasse em Contemplação de Ouro Preto (1950), no entanto, é Siciliana o marco definitivo da passagem de Murilo a "poeta maior":

\footnotetext{
Embora fosse ocioso perguntarmo-nos como teria sido sua obra em sua residência na Europa, por dezoito anos e embora sua maturidade já se manifestasse no Contemplação de Ouro Preto, que começara a escrever antes de sua passagem para a Europa, não é menos evidente a diferença desse com o primeiro livro que dependeu da ambiência italiana sistemática: o Siciliana, composto entre 1954 e 1955. (As datas indicam um problema que não sei resolver: como apontam para anos anteriores à sua transferência, não sabemos como se explica o impacto causado pela Sicília.) (LIMA, 2002, p. 71).
}

A propósito, o crítico menciona essa diferença entre os livros não só uma, mas duas vezes, pois na terceira parte de seu texto, "O agônico na abertura de Contemplação" - que foi uma conferência proferida em resposta a um convite para discursar sobre a obra de Murilo - o crítico afirma que irá concentrar sua fala no livro citado: "Cogitei então a concentrar-me no que julgo seu primeiro livro de maturidade, o Contemplação de Ouro Preto, publicado originalmente em 1954." (2002, p. 95). Ainda que de modo velado, posto que o crítico não especifica a que tipo de diferença entre os livros se refere, sabemos que Costa Lima vê um desnível de valor qualitativo entre estes livros. Assim, Siciliana seria o ápice da poesia muriliana já que "a Sicília parece ter se assenhoreado de Murilo em súbito amor, infletindo uma vez por todas o rumo de sua produção" (2002, p. 71).

Aliás, o crítico não esconde suas opiniões judicativas a respeito da obra de Murilo Mendes, já que, no início de seu texto ele afirma ter uma preocupação em 
especial, demonstrar "como se afirma o poeta maior". A propósito, o crítico só indica uma definição para o que seria um "poeta maior" no fim de sua interpretação, após já ter discutido esse provável encaminhamento da poesia de Murilo em direção a uma secura e economia verbais: "Murilo então se torna poeta maior: aquele que faz da sintética intensidade o seu princípio.” (2002, p. 78).

Após essa observação do crítico, espera-se que ele apresente o que ele considera por intensidade, contudo ele não realiza nenhuma explicação a respeito. No entanto, fica a questão: será que, realmente, é só através da síntese que se alcança a intensidade em poesia? Seriam desprovidos de intensidade poemas extensos como A Divina Comédia ou Os Lusíadas, por exemplo?

Voltemos ao texto de Costa Lima, no qual é possível flagrar que o crítico considera a influência religiosa como um dos obstáculos propiciadores desse atraso no percurso evolutivo da poesia de Murilo Mendes. Diz o crítico: "Segundo nossa hipótese, para essa forma baça, originada de uma ansiedade primária, contribuía o próprio cristianismo do autor. Mas não por decorrência da adesão a uma fé, mas porque ela era vivida ao contato mais estreito com o mundo.” (2002, p. 77). Esta irregularidade formal advinda da influência do cristianismo na poesia muriliana não é sinal de bons antecedentes para Costa Lima, já que ela fez com que Murilo demorasse a alcançar a "sua verdadeira voz" que será valorizada por Costa Lima, a do poeta construtor consciente e premeditado, criador sintético e econômico.

Destaque-se que Luiz Costa Lima é um dos autores de mais notável produção crítico-teórica dos últimos anos no Brasil e um dos mais conscientes de seu exercício, na medida em que, numa espécie de prática metalinguística, demonstra em seus textos o caráter arriscado de sua análise, a possibilidade de equívocos etc. Se a crítica para Haroldo de Campos mostra-se como discurso voltado para outro discurso, no caso de Costa Lima, esta metalinguagem é também voltada sobre si mesma. Afirmamos isso porque é possível notar que ocorre em sua crítica literária um desnudamento dos bastidores de seu pensamento crítico-teórico por meio do qual o autor repele a certeza ilusória de desvendamento daquela verdade absoluta da obra, certificando, assim, a defesa e o reconhecimento da reavaliação sistemática como requisito fundamental para o exercício crítico.

Assim, no decorrer da análise de Costa Lima, fica nítido que também encontramos nela o elogio do construtivismo poético, fato que, conforme já aludimos, 
aponta para uma postura teórico-crítica datada que predominou em certo período de nossa crítica literária e, deste modo, estes críticos respondiam ao horizonte de expectativas de sua própria época. Ainda no que diz respeito à interpretação de Costa Lima, é possível entrever que, além da aclamação do construtivismo, também encontramos uma restrição à poesia muriliana devido à sua dimensão religiosa.

Compreendemos que a divisão de obras literárias em fases é um procedimento didático muito comum realizado tanto pelos manuais de história da literatura quanto pela própria crítica especializada com o intuito de facilitar a apreensão e o estudo das obras de autores consagrados da literatura. No entanto, a questão principal, aqui, é que essa tendência crítica, ao atribuir uma evolução à poesia de Murilo, realiza essa divisão de maneira tendenciosa - pois o fazem limitados por concepções pré-concebidas do fazer poético, influenciados pelas tendências em voga em seu momento histórico.

\subsection{A perspectiva de Alfredo Bosi}

Podemos apreender facilmente o espírito didático da crítica na interpretação que Alfredo Bosi realizou da obra muriliana. Fator preponderante para essa peculiaridade é o fato de que o texto de Bosi de que falaremos é parte integrante de seu mais célebre livro, História Concisa da Literatura Brasileira, publicado pela primeira vez em 1970. Desde então, devido ao seu grande êxito, principalmente entre o público acadêmico, o livro se tornou um dos mais respeitados manuais de literatura brasileira e sofreu várias e constantes reedições.

Caracterizam as histórias literárias uma perspectiva sintética, dada a amplitude do material com que tem de lidar. Daí serem as histórias da literatura obras em que não se visa um estudo profundo de cada autor ou obra. Tratam-se de obras de apresentação, que se destinam a servir de referência para estudos posteriores. Entretanto, o simples fato de se escolher falar de certas questões, autores e obras e utilizar um método específico para isso em vez de outros, já indica um julgamento ou uma predisposição estético-ideológicos, para a qual colabora todo um prévio sistema de valores.

Assim sendo, verifica-se que a subjetividade do autor participa do discurso historiográfico, assim como do discurso crítico, ainda que tenda a ser encoberto sob o véu da tentativa de objetividade. Ainda que ocultadas no panorama geral em que se 
incluem, aparentemente, inocentes divulgações de dados biográficos e observações meramente informativas, muitas vezes, as idiossincrasias, preferências pessoais e orientações ideológicas podem ser captadas.

Ora, o historiador literário foi e é, acima de tudo, um leitor. Entretanto, ao outorgar-se a tarefa de empreender a construção de uma história da literatura, assume, inapelavelmente, a contingência de todo discurso histórico que traz em si as marcas de seu presente. Como aponta Leyla Perrone-Moisés em Altas Literaturas (1998), a história literária está fadada, mais do que qualquer outro tipo de história a assumir-se como uma releitura do passado à luz dos valores presentes, pois seu objeto é um passado permanente que se presentifica a cada leitura. $\mathrm{O}$ historiador literário escreve voltado para o passado como se o seu presente lhe permitisse um ponto de vista abrangente e conclusivo que autorizasse o seu julgamento e lhe conferisse a objetividade da distância (PERRONE-MOISÉS, 1998). Conclui-se, então, que o historiador literário escreve de um local já (de) limitado e definido temporalmente, de modo que isso, com certeza, também influencia o seu sistema de valores e estará inscrito na forma final de sua abordagem.

Com isso, nas histórias da literatura, a dimensão de uma obra de um determinado autor recebe uma redução a poucas características ou fatos, o que pode levar, facilmente, a proposições equivocadas devido ao alto grau de generalização que lhe é imposto pela própria ordem discursiva. Deste modo, alguns autores acabam atuando, muitas vezes, como Procusto, deitando em seu texto e esticando ou cortando, conforme caso seja adequado a sua interpretação, a obra para enquadrá-la e emoldurá-la em certa tradição ou momento/movimento histórico. É óbvio que colaboram, para isso, as preferências literárias e a orientação estético-ideológica do crítico/historiador, definidas, em boa parte, pelo contexto histórico e institucional no qual ele se insere.

O livro de Bosi não foge à organização padrão de uma história da literatura. Como a maioria delas elabora uma narrativa historiográfica orientada pela periodologia estilística e abrange desde os tempos coloniais até as tendências contemporâneas da literatura brasileira à época de publicação do volume. Ainda que preso às normas exigidas pelo gênero, é perceptível que a História Concisa de Bosi consiste em uma avaliação literária sólida e de firme embasamento na medida em que o crítico parece buscar sempre uma compreensão ampla do fenômeno literário. Distingue-se desde as 
primeiras páginas que Bosi é atento tanto aos aspectos estilístico-formais das obras que analisa, quanto à perspectiva histórico-social.

No que diz respeito à interpretação que realiza da obra de Murilo, Bosi apresenta uma rápida análise do conjunto da obra do poeta até a data de escrita da sua história da literatura. É que, a essa altura, em plena década de $60^{13}$ Murilo ainda era um autor em ação na literatura, o que impediu que Bosi tivesse uma visão do conjunto da obra do poeta. Obviamente não estamos preconizando com essa pergunta que um crítico/historiador não possa analisar a obra de um escritor ou poeta seu contemporâneo. No entanto, essa limitação temporal indica certa restrição e comprometimento da perspectiva de Bosi, já que o seu presente, ou melhor, o da produção de seu volume, além de não lhe permitir aquela objetividade da distância à qual alude Leyla PerroneMoisés (1998), impossibilitou-lhe a apresentação de um ponto de vista que abrangesse a obra de Murilo como um todo já constituído. Assim sendo, o que Bosi nos apresenta é uma visão do conjunto da obra de Murilo Mendes até então produzida, o que elimina os caminhos que sua obra tomou ou poderia tomar daquele ponto em diante.

Feita a ressalva, importa observar que Alfredo Bosi é peremptório em afirmar que houve uma aproximação e uma busca de Murilo, ao longo de sua trajetória até então, por "dimensões concretas" ${ }^{14}$. Em nosso entender, essa visão aproxima Bosi da perspectiva de Haroldo de Campos, embora haja uma divergência entre os dois quanto ao momento de tal aproximação. Se, para Haroldo, a "obsessão do concreto", como vimos, sempre existiu em Murilo, para Bosi, teria um marco inicial: "Desde os Sonetos Brancos, a vocação para o real, tão forte que abraça também o real-imaginário, o suprareal, tem levado o poeta a avizinhar-se da paisagem e dos objetos em busca de formas e dimensões concretas" (2004, p. 450).

Segundo Bosi, esse momento pode ser verificado devido ao recurso de Murilo a metros exatos e a uma maior disciplina semântica, ou seja, certa retomada e revisitação de formas e modelos tradicionais de composição poéticas. Daí não estranharmos a eleição que Bosi realiza para demarcar esse momento em um livro como Sonetos Brancos (1948) que se insere, conjuntamente com outros importantes livros de nossa poesia moderna - como Claro enigma (1951) de Carlos Drummond de Andrade e Livro

\footnotetext{
${ }^{13}$ O livro História Concisa de Bosi foi escrito durante os anos de 1968 e 1969, como informa o próprio crítico (BOSI, 2006, p. 386).

${ }^{14}$ É claro que a ideia de concreto/concretização de Bosi não é a mesma que a de Haroldo já que, na crítica do poeta concretista, a carga semântica deste termo é sobrecarregada com a intenção de capturar/cooptar a obra de Murilo para o Concretismo e Bosi não tem esse objetivo.
} 
de Sonetos (1949) de Jorge de Lima - naquele momento de classicização na poesia modernista analisado por alguns críticos como José Guilherme Merquior ${ }^{15}$, por exemplo. Para Merquior, o fenômeno geral da classicização ${ }^{16}$ consistiu, basicamente, não "numa negação do sentimento do mundo modernista, mas sim, apenas, numa purificação de linguagem, acompanhada ou não, conforme o caso, de um classicismo temático.” (MERQUIOR, 1994, p. 16-17). Merquior afirma, portanto, que a linguagem moderna ainda permanecerá nessas obras, mesmo que sob uma forma mais pura e desprovida da mescla estilística que caracterizaria as primeiras manifestações do modernismo.

Esta adesão de Murilo às formas fixas contém ainda a marca da ambivalência tão característica ao poeta, já que este seu preito à tradição também foi marcado pelo experimentalismo com essas formas padronizadas de composição. Tal fato foi destacado por Júlio Castañon Guimarães (2001), que classificou Sonetos Brancos como a "experimentação de uma forma clássica", uma vez que, apesar de adotar a forma soneto, os poemas são caracterizados pela ausência de rima. Castañon indica outro fator experimental dessa obra já que nela Murilo também rompe com a métrica promovendo, segundo o crítico, um entranhamento entre desenvolvimento discursivo e efeitos sonoros. Merquior (1980) também nos alerta contra a possível crença de um tributo passivo à tradição efetuado por Murilo, pois, segundo o crítico, esse estilo classicizado, esse "modernismo classicizado" de Murilo não abandonará tanto a figuração surreal ${ }^{17}$, tão característica à sua poesia, quanto aquele modo explosivo do dizer muriliano que o acompanhará ao longo de toda a sua trajetória.

A perspectiva de Alfredo Bosi também converge com a de Haroldo no que diz respeito ao tratamento vocabular realizado por Murilo. Para o segundo crítico, o poeta teria reduzido seu léxico outrora tão variado; para o primeiro, ocorre nessa poesia um "acirramento da disciplina semântica", o que não seria possível se o poeta não houvesse filtrado sua diversidade vocabular.

\footnotetext{
${ }^{15}$ Merquior analisa essa questão de forma detalhada em dois de seus livros, A astúcia da mimese (1972) e Verso universo em Drummond (1975).

${ }^{16}$ Segundo Merquior, esse fenômeno abarcou, também, a poesia moderna num contexto internacional na medida em que foram vários os modernistas classicizados sem deixar de ser modernos, como, por exemplo, o caso de T. S. Eliot de Four Quartets, do Eugenio Montale de La Bufera e altro, e do livro Statische Gedichte, do poeta alemão Gottfried Benn. "Notas para uma muriloscopia" In: MENDES, Murilo. Poesia Completa e Prosa, 1994, p. 17.

${ }^{17}$ Ocupar-nos-emos da dimensão surreal da poesia de Murilo mais detalhadamente em nosso segundo capítulo.
} 
Merece ser recuperado, aqui, um apontamento de Luiz Costa Lima em relação à interpretação de Alfredo Bosi. Ao comentar sobre o descaso da crítica literária brasileira com as primeiras produções de Murilo, Luiz Costa Lima destaca que Bosi foi uma das poucas exceções a essa regra. Logo em seguida, Costa Lima cita um trecho do texto de Bosi:

\begin{abstract}
Alfredo Bosi é um desses poucos: "[...] O clima onírico e alucinatório que envolveria a sua poesia" se iniciaria com O Visionário (1941), ao passo que "o ciclo de poemas humorísticos anteriores a 30 [...] fazem o giro piadístico de um 'Brasil morno e provinciano e ecoam a maneira inicial de Mário e Oswald de Andrade". (LIMA, 2002, p. 71)
\end{abstract}

Ainda que considere a importância da interpretação de Alfredo Bosi, já que se trata de um dos raros críticos que analisaram os primeiros livros de Murilo, Costa Lima aponta que, de um "ponto de vista qualitativo", este comentário de Bosi merece uma ressalva, pois Murilo, segundo Costa Lima, demorou a encontrar o "mundo substantivo". O crítico ainda demarca, claramente, sua discordância em relação a Bosi ao destacar que o que este considera como "epigonismo piadístico" não se confunde com a prática do poema piada, que, segundo Mário de Andrade (1942), foi um dos maiores defeitos do modernismo ${ }^{18}$.

Vale comentar aqui, ainda que de modo breve, "A interpretação da obra literária", outro texto de Bosi, no qual o crítico nos oferece uma reflexão sobre como se deve proceder à interpretação de uma obra literária. Para Bosi, é imprescindível que o intérprete respeite o "caráter de mobilidade, incerteza, surpresa, polivalência e, até certo ponto, indeterminação, que toda fala implica" (1988, p. 278), pois ele está diante de um efeito verbal estilizado, radicado em um processo sinuoso e, muitas vezes, obscuro para o próprio criador.

Nesse trânsito entre o seu texto e o texto alheio, segundo Bosi, o crítico há de estar atento para não dominar o objeto e destruí-lo com seus instrumentos de interpretação, pois a exigência mais rigorosa desta é refazer a experiência simbólica do

\footnotetext{
${ }^{18}$ A desqualificação dos poemas-piada efetuada por Mário de Andrade à qual alude Costa Lima, foi realizada na conferência $O$ Movimento Modernista proferida em 1942, na qual, por meio de uma espécie de mea culpa e autocrítica, o autor teceu um balanço geral do movimento definindo e destacando tanto sua herança quanto os seus limites e equívocos. A fim de esclarecer essa questão de uma forma o menos tendenciosa possível, vamos nos valer da contribuição de João Luiz Lafetá (2000), para quem a forma de se colocar perante os problemas sérios, através dos poemas-piadas, reflete-se na recusa e no afastamento de toda espécie de academicismo, donde se conclui que sua prática não tenha sido um mero evento irrefletido em nossas letras: "o humor vai aqui além de qualquer inconseqüência, porque penetra fundamente na poética e contribui para a expansão de um estilo desalienado e dessacralizante." (LAFETÁ, 2000, p. 245).
} 
outro. Se o crítico não tiver cuidado, pode acabar adaptando, reduzindo e desrespeitando a singularidade e a dinâmica de seu objeto para enquadrá-lo numa concepção de literatura ou de arte literária que estaria alicerçada em seus pré-conceitos. Acreditamos que, embora Bosi mostre ter consciência das especificidades do exercício crítico, acaba por cair na própria armadilha que denuncia, pois, ao demarcar e indicar esse ponto de evolução na trajetória poética de Murilo, ele deixa entrever uma clara interferência ideológica, já que esta atitude privilegia certo tipo de poética. Um ponto crucial pelo qual é possível vislumbrar seu posicionamento está na escolha efetuada por Bosi do livro representante dessa evolução qualitativa da poesia muriliana. Depois de comentar sobre a "vocação para o real" dessa poesia e que esta conduzia o poeta a aproximar-se dos objetos e das paisagens em busca de dimensões mais concretas, Bosi manifesta, nesses termos, a sua escolha:

A disciplina semântica e o recurso a metros exatos são os aspectos mais evidentes dessa diretriz não só nos Sonetos Brancos, como também nessa obra-prima de visão e ritmo que é Contemplação de Ouro Preto, até agora o ponto mais alto da carreira literária de Murilo Mendes. (BOSI, 2006, p. 450)

Segundo Bosi, essa busca por maior rigor que ocorre em Murilo é uma tendência "que é um dos sulcos mais fundos da poesia contemporânea e que aproxima poetas de línguas diversas (...) enquanto repropõe à Estética a própria questão da objetividade" (2006, p. 450). Ao ressaltar isso, o crítico deixa bem evidente quais os elementos em poesia e, por extensão, que tipo de poesia ele valoriza: aquela que recoloca na contemporaneidade e no âmbito da própria arte a questão da objetividade. Por isso não nos espanta que Bosi realce, na poesia de Murilo, a disciplina semântica e o recurso a metros exatos. Em sua perspectiva, o crítico expressa de forma clara não só a existência de uma tendência construtivista predominante e orientadora da poesia daquele período, como também o seu juízo de valor, de que esta diretriz seria uma orientação mais madura para a poesia moderna.

Até aqui, nota-se uma divergência significativa que diz respeito ao momento desse salto evolutivo da poesia de Murilo apregoado pelos críticos já analisados. Como vimos, cada um deles elegeu um livro distinto: para Haroldo de Campos, esse amadurecimento está representado por Tempo Espanhol, de 1959; para Alfredo Bosi por Contemplação de Ouro Preto, de 1954; e para Luiz Costa Lima por Siciliana, também lançado em 1959. Ora, se estes críticos afirmam que há na poesia de Murilo um 
momento superior, de uma maior depuração e regularidade formal, por que ocorre, então, essa divergência?

Num breve relance, percebe-se que os críticos elegeram livros que se sucederam cronologicamente na trajetória muriliana, sendo o primeiro, neste caso, o livro de 1954, Contemplação de Ouro Preto; o segundo é Siciliana, composto entre este ano e o de 1955; e, por fim, Tempo Espanhol, escrito entre 1955 e 1958. Seguindo a perspectiva dessa tendência, que defende que a poesia muriliana caminhou sempre em prol desse rigor, torna-se claro por que o motivo da eleição do melhor livro ocorreu num sentido diacrônico. Nesta linha de raciocínio, em cada obra Murilo teria aprimorado cada vez mais esta sua busca pela "poesia do real" ou por aquela que seria, para estes críticos analisados, a "real" poesia muriliana.

\subsection{A perspectiva de João Alexandre Barbosa}

A única exceção no que tange à escolha de um livro auge de Murilo Mendes é a do crítico João Alexandre Barbosa, que não elege nenhum deles em especial. João Alexandre Barbosa possui importantes ensaios sobre diversos poetas nacionais e estrangeiros, dentre os quais se destacam, principalmente, os modernos poetas franceses: Baudelaire, Mallarmé e Paul Valéry. Sob orientação de Antonio Candido no final dos anos 60, concebeu um trabalho importante sobre a crítica de José Veríssimo, $A$ tradição do impasse: linguagem da crítica e crítica da linguagem em José Veríssimo. Este seu trabalho já nos indica que existia uma preocupação em João Alexandre com vistas a compreender como o pensamento crítico se desenvolveu no Brasil, bem como nos mostra que estamos diante de um crítico possuidor de um estilo e um método críticos bem peculiares.

No interior dessa primeira corrente crítica que ora analisamos, a posição que João Alexandre ocupa, devido ao seu estilo mais ensaístico e a outros fatores que comentaremos posteriormente, é bem singular e sutil. Se não fosse por algumas questões que apontaremos mais adiante, ele poderia, por vezes, estar incluído no interior da segunda tendência já mencionada e que será analisada em nosso segundo capítulo. 
O texto por nós aqui considerado, "A convergência poética de Murilo Mendes" ${ }^{19}$, está presente no livro A Metáfora Crítica, de 1974, que reúne, além de um ensaio sobre o Modernismo e de outro no qual Barbosa comenta a leitura que Valéry realizou de Mallarmé, ensaios sobre os poetas João Cabral de Melo Neto, Carlos Drummond de Andrade e Murilo Mendes.

Com a epígrafe de A Metáfora Crítica, João Alexandre oferece, de início, uma pista sobre o que iremos encontrar ao longo do livro. Trata-se de um trecho retirado de Blindness \& Insight, de Paul de Man: "cristicism is a metaphor for the act of reading, and this act is itself inexhaustible" ${ }^{20}$. É assim que o próprio título aponta não só para um dos assuntos que serão abordados, a metáfora, mas serve também como uma espécie de definição para o próprio exercício crítico.

Encontra-se disseminada, ao longo desse conjunto de ensaios, uma série de apontamentos e cogitações que especificam o que, na opinião de João Alexandre, vem a ser essa tarefa de leitura. Como se vê, o crítico reflete sobre sua própria prática no próprio momento em que está a desenvolvê-la, seja por meio de reconsiderações e retomadas de conceitos ao longo dos textos, seja mesmo por meio de reformulações do que até então vinha sendo dito, algo semelhante ao que acontece com a crítica de Luiz Costa Lima, conforme já apontamos. Ao estudar as relações entre o real e o poético, entre linguagem e representação, só para citar duas das questões tratadas com extrema felicidade pelo crítico, João Alexandre desnuda e questiona, também, a própria linguagem da crítica sobre as poéticas da modernidade.

No primeiro capítulo de A metáfora crítica, intitulado "Exercícios de definição", o autor realiza uma espécie de fundamentação de base, teorizando a respeito de várias questões centrais que serão recuperadas e redimensionadas ao longo dos outros ensaios componentes do livro. Uma ocorrência semelhante é operada num outro livro seu, As ilusões da modernidade: notas sobre a historicidade da lírica moderna (1986), no qual temos como primeiro capítulo um texto intitulado "Ilusões da Modernidade", que se apresenta, segundo o próprio autor, como uma tentativa de delineamento teórico que possa contribuir na discussão da questão da historicidade da poesia moderna. Ainda no prefácio de $A$ metáfora crítica, João Alexandre indica que os textos ali reunidos

\footnotetext{
${ }^{19}$ Embora nosso título seja homônimo a esse texto de João Alexandre, isso não significa que partilhamos de sua perspectiva. A escolha de nosso título foi motivada pelo fato de acreditarmos que em Convergência (1970) podemos acompanhar toda a trajetória de Murilo. Esse trajeto será empreendido em nosso terceiro capítulo.

20 "Crítica é uma metáfora para o ato de leitura, e este ato é em si inesgotável". Tradução nossa.
} 
consistiriam apenas de "anotações de leitura de poesia e poetas", fato para o qual, ademais, já remete o subtítulo do volume Queremos indicar com essas referências a certa homologia estrutural entre os livros, algo do método crítico de João Alexandre que se pauta, principalmente, pela ausência de um processo rigoroso e sistemático já que ele encarava suas interpretações sob esse signo do exercício da leitura.

Parece-nos que o crítico tentava construir sua perspectiva recusando a adoção de um sistema ou referencial, seja estético ou ideológico, que fixasse de modo rígido e engessado um único sentido para o texto literário que estava analisando; daí não estranharmos que ele incorpore e traga para sua crítica esse sentido de uma leitura consciente de sua transitoriedade e precariedade diante da infinita riqueza do texto literário. Pensamos que decorreu disso certo pendor à teorização na crítica de João Alexandre, fato que se verifica na elaboração efetuada pelo crítico de certas noções que o auxiliaram no tratamento dos autores e das questões com as quais se viu envolvido. Em relação a isso, destaque-se, por exemplo, a noção de "leitura do intervalo" que deu nome a um volume no qual João Alexandre buscou refletir sobre a representação da realidade elaborada pelas obras de ficção.

Assim como outros críticos, João Alexandre também aponta o descaso da crítica literária brasileira com a obra de Murilo. Segundo o crítico, um fato que contribuiu para essa demora da recepção da obra muriliana, é o lugar-comum de sua obra ser insistentemente apontada como hermética. Para Barbosa, isto só provocou classificações unilaterais que reforçaram a multiplicidade imanente da obra de Murilo, o que colaborou para a perda de uma visão de conjunto que poderia ser capaz de unificá-la. Deste modo, João Alexandre indica que procurará em Murilo uma visão unificada da multiplicidade de sua obra que, a seu ver, não foi percebida pela crítica literária brasileira.

Embora João Alexandre não eleja explicitamente nenhum momento da poesia muriliana como qualitativamente superior, como os outros três críticos dessa tendência, é possível perceber, nas entrelinhas de seu texto, sua predileção pela dita "segunda fase”. Um primeiro indício pode ser observado devido à escolha, efetuada pelo crítico, de um livro de Murilo por meio do qual ele possa iniciar e propor uma reflexão renovada sobre a sua poesia. Neste ponto João Alexandre propõe a consideração de Convergência, último livro de Murilo, o que indica que, para o crítico, estaria situado justamente na fase tida como a superior, a segunda. Vejamos como João Alexandre 
expõe o motivo desta sua escolha: "Que o seu último livro de poemas se chame Convergência é, por isso, muito significativo. E é a partir de sua existência que pretendo rastrear os elementos que me permitam configurar um modelo de reflexão acerca da extensa obra de Murilo Mendes." (1974, p. 122).

Outro ponto pelo qual podemos apreender o posicionamento de João Alexandre é por meio do diálogo que ele trava com a interpretação que Haroldo de Campos realizou da obra muriliana, a qual comentamos anteriormente. $\mathrm{Na}$ verdade, a atitude do crítico ultrapassa o mero diálogo na medida em que ele demonstra, de forma transparente, sua adesão à perspectiva de Haroldo. É de fácil verificação, posto que são expressas de forma explícita a cumplicidade e a concordância de João Alexandre com a perspectiva haroldiana, chegando esse último a afirmar tratar-se o poeta-crítico de um dos melhores leitores da poesia de Murilo Mendes.

Esmiuçando um pouco mais esse diálogo que João Alexandre trava com o ensaio de Haroldo, vemos que, sempre que possível, o crítico destaca a pertinência da perspectiva haroldiana, ressaltando o fato de o poeta-crítico ter apresentado uma reflexão verdadeiramente renovadora sobre a obra de Murilo Mendes:

\footnotetext{
o ensaio de Haroldo de Campos oferece um esquema de reflexão sobre a poética de Murilo Mendes que, em termos de construção, seja capaz de legitimar a sua singularidade dentro daquela geração brasileira de poesia que surge sob o impulso da liberação pregada e praticada pelos modernistas de 22. (BARBOSA, 1974, p. 121-122)
}

Para João Alexandre, ao apontar a imagem e o ritmo como elementos de realização dos poemas de Murilo num nível de estruturação lingüística e não apenas como elementos colados à significação, Haroldo assegurou a possibilidade de uma nova via de reflexão sobre a poesia muriliana. Para João Alexandre, a semântica concreta apontada pelo poeta-crítico na poesia muriliana responde adequadamente "ao rigor fundamental da poética de Murilo Mendes: uma direção para o real assumida sob o controle de uma linguagem cada vez mais consciente de seu direcionamento" (1974, p. 122).

Ao iniciar sua análise de Convergência, João Alexandre menciona que a última obra poética de Murilo em vida "é resultado de um projeto e não de uma aderência" (1974, p. 123). Ao anunciar isso, o crítico indica que esse fato já está assinalado desde a palavra que dá título ao livro e que pode ser compreendida "em função de todo o projeto de Murilo Mendes, como o espaço em que os planos do real e do poético confluem para a configuração de um discurso único." (1974, p. 131). Nesta parte, o crítico demarca 
mais um ponto de contato entre a sua perspectiva e a de Haroldo, pois ambos manifestam a ideia de que a poesia muriliana, apesar do aparente "caos", é o resultado de um projeto poético.

Durante sua consideração sobre o último volume de Murilo, João Alexandre afirma que, por meio de sua leitura, "é possível exercer a intertextualidade sobre todo um corpus poético mais amplo que é a obra de Murilo Mendes" $\left(1974\right.$, p. 125) ${ }^{21}$. Ao comentar sobre os "grafitos" e os "murilogramas", as duas seções da primeira parte de Convergência, o crítico afirma que estes "serão modos de concretização, pela palavra, dessa "convergência fundamental" (1974, p. 126) e que, deste modo, o exercício do poema inclui também, em Murilo, o exercício da leitura dos objetos que se oferecem à sua circunstância. Estes "objetos" sobre os quais Murilo se debruça, em Convergência, são, em sua grande maioria, os referenciais de toda uma tradição histórico-cultural, pois nesses poemas o poeta Murilo Mendes (re) lê e homenageia toda uma tradição literária e artística à qual ele demonstra se filiar. Percebe-se que João Alexandre considera Convergência como o espaço poético no qual Murilo irá exacerbar e esmiuçar suas dissonâncias anteriores e que, por meio disso, a integração de sua obra foi mantida e redimensionada ${ }^{22}$.

Embora se perceba em João Alexandre um desejo de não contaminar suas interpretações com interferências e idiossincrasias estético-ideológicas, podemos afirmar que ele não alcança essa meta, simplesmente porque é impossível manter uma plena objetividade no exercício crítico. O simples fato de se escolher falar de determinado autor ou obra e não de outros já indica, como vimos com Leyla PerroneMoisés (1998), a expressão de um julgamento. A posição estético-ideológica de João Alexandre, se assim podemos dizer torna-se visível se observarmos as obras dos poetas e escritores que mais lhe despertaram interesse. São autores que podem ser vistos como os arautos do construtivismo em poesia: Paul Valéry e João Cabral de Melo. No caso específico deste último, João Alexandre lhe dedicou um livro inteiro, A Imitação da Forma, estudo no qual o crítico teceu uma profunda reflexão acerca da relação entre existência e linguagem poética a partir da poesia cabralina.

\footnotetext{
${ }^{21}$ Esta consideração de João Alexandre em relação a Convergência assemelha-se, embora guardada as devidas diferenças, a de Sebastião Uchôa Leite (2003), crítico da segunda tendência que será visto mais adiante. .

${ }^{22}$ Recorde-se que, segundo Haroldo, dois elementos presentes desde os primeiros livros de Murilo já apontavam para essa dissonância presente em sua poesia, além de já indicar, de forma precisa, a evolução pela qual sua poesia passaria: a dissonância imagética e a rítmica dissonante.
} 
Vejamos mais um apontamento de João Alexandre a fim de esclarecer um pouco mais a sua posição: "Sem (...) desprezar o núcleo de suas preocupações essenciais, Murilo Mendes, em Convergência, opera a redução do real à linguagem, por assim dizer, 'textualizando' as dimensões 'metafísicas' de obras anteriores.” (1974, p. 130). João Alexandre indica, ao apontar a existência dessa textualização, que até os temas de caráter metafísico/místico da poesia de Murilo sofreram um impacto de maior rigor nesse seu último livro. Neste ponto, observa-se mais um ponto comum entre a sua perspectiva e a de Haroldo que, ao referir-se à existência de uma "semântica de concreções" em Tempo Espanhol, aponta para a ocorrência do mesmo processo nesses termos:

até os temas metafísicos do poeta (que, é preciso que se diga, sempre tendeu a uma religiosidade militante, de padre-operário, antes que ao misticismo de teor contemplativo) se convertem em signos de física rigorosidade: seu anjo é matemático, sua cruz é geométrica, sua morte é um tempo físico. (CAMPOS, 1970, p. 62).

Note-se que João Alexandre se limita a designar as primeiras produções murilianas como dotadas dessas dimensões metafísicas sem a explicitação ou o mínimo comentário do que seriam essas dimensões. Ora, elas nos remetem imediatamente ao momento delimitado por essa primeira tendência como a "primeira fase muriliana", classificada e sedimentada como uma fase "surrealista mística-cristã", na qual há a predominância de uma alta imagética aliada a referenciais bíblicos.

Finalizando nossos comentários sobre o texto de João Alexandre, cremos poder divisar também em sua crítica o a defesa de que a melhor poesia de Murilo Mendes é aquela dotada de um maior rigor e controle poético. Deste modo, o crítico nos indica ser, também ele, partidário de uma posição crítica explicitamente datada, muito comprometida com as idéias e as concepções de uma época como a dos outros críticos que já comentados neste capítulo.

Esse ponto de vista localizado a partir do qual esses críticos interpretaram a poesia de Murilo Mendes aponta para aquilo que o crítico inglês Frank Kermode (1993) designou como "controle institucional da interpretação" praticado por certas instâncias de poder disseminadas no meio literário, representadas, sobretudo, pela crítica especializada e acadêmica. Estas instâncias são responsáveis por conduzir as obras literárias àquele sentido único e engessado ao qual João Alexandre parecia querer escapar, mas que, no entanto, acabou também ele, por edificar no que tange à poesia de Murilo Mendes. É por esse viés, da construção de um sentido demasiado partidário, que 
encontramos na recepção crítica de Murilo essa divisão com fins evolutivos e valorativos de sua poesia.

$\mathrm{Na}$ busca por uma compreensão do motivo do estabelecimento dessa leitura com fins evolutivos efetuada por parte de sua crítica, recorremos, mais uma vez, a Frank Kermode (1993), que assevera que este tipo de atitude, de traçar um perfil evolutivo dos autores que se analisa, tem sido o princípio geral e orientador da crítica literária. Segundo o crítico, isso ocorre, justamente, porque o que se busca ao exercer esse tipo de crítica, por mais que se afirme o contrário, é sempre a questão do valor.

Parece-nos, assim, que a atividade dos críticos dessa primeira tendência é limitada no que diz respeito à interpretação da poesia muriliana devido aos pressupostos estéticos e ideológicos que as fundamenta. Isso acontece, sobretudo, quando eles menosprezam a dita "primeira fase" do poeta, tanto pela sua dimensão surreal quanto pela dimensão religiosa nela predominantes.

A propósito dessa tentativa de minimização da importância da dimensão surreal da poesia de Murilo Mendes já nos tinha chamado a atenção José Guilherme Merquior (1980): “Atualmente, a tendência da crítica é minimizar a importância do elemento surreal em Murilo, salientando a sua pouca intimidade - tão pequena quanto a de seu quase-sósia Éluard - com os (anti) cânones da escrita automática.”. (1980, p. 151).

Todavia, convém destacar que essa atitude de desconsideração e apagamento desse elemento vital à poesia de Murilo Mendes que é o surrealismo, não ocorreu somente no que diz respeito à sua obra. Ela pode ser percebida num contexto maior no interior da própria crítica e historiografia literárias brasileiras, que pareceram sempre preterir e/ou negligenciar as obras de autores que manifestaram algum diálogo com o movimento francês.

Obviamente ultrapassaria os limites de nosso trabalho empreender uma reflexão mais aprofundada sobre esse assunto; cabe-nos, assim, apenas levantar algumas suposições a respeito. Pode-se levantar a hipótese de que essa negligência da crítica e historiografias literárias brasileiras para com a presença do surrealismo entre - isso se refletiu, por exemplo, numa recepção tardia ou quase inexistente de alguns autores que incorporaram elementos do surrealismo em suas obras - tenha ocorrido devido à febre do nacionalismo que vigorava em nossas letras à época das principais manifestações 
surrealistas na década de $20^{23}$. No entanto, no que tange à ausência de uma reflexão sistemática sobre o surrealismo e suas implicações primeiras em nossas artes em geral, podemos dizer que, nos últimos anos, esse panorama vem sofrendo mudanças significativas. Alguns trabalhos que despontaram nas últimas décadas abriram a discussão sobre esse acontecimento dispostos não só a analisar essa pseudo-ausência do surrealismo no Brasil ${ }^{24}$, como também, a recuperar e revitalizar uma série de artistas influenciados pelo surrealismo que foram omitidos, não só entre nós, mas também no âmbito latino-americano como um todo ${ }^{25}$.

No entanto, essa tentativa de redução da relevância não foi aplicada somente em relação à dimensão surrealista da poesia de Murilo Mendes, mas também em relação à dimensão religiosa de sua poesia. Para Luiz Costa Lima, por exemplo, a adesão do poeta à religião católica é um entrave à forma e à regularidade de sua poesia. Essa atitude é verificável, também, no panorama geral de nossa crítica literária já que as obras de outros autores, não só a de Murilo, parecem ter sofrido certas restrições devido à adesão de seus autores à fé católica ${ }^{26}$.

Essa atitude interessada de nossa crítica se deve, a nosso ver, ao modo com que, sobretudo a partir da década de 30 , as polarizações ideológicas e políticas se estabeleceram e passaram a se manifestar de forma acirrada no meio literário nacional. Este fenômeno foi analisado com extrema sagacidade pelo crítico João Luiz Lafetá em 1930: a crítica e o Modernismo (2000), trabalho no qual o crítico refletiu sobre como o movimento modernista no Brasil desenvolveu-se como transição de um projeto estético, presente nos anos de 1920, para um projeto ideológico, que caracterizou os anos de

\footnotetext{
${ }^{23}$ Essa hipótese é levantada principalmente por Sérgio Lima em "Alguns dados sobre a construção interessada de uma ausência: a do Surrealismo no Brasil ou... 'A cada um o seu desejo"” (1994), trabalho no qual o autor apresentou uma série de manifestações que promoveram ardentemente o surrealismo entre nós, além de ressaltar as obras de vários artistas plásticos e escritores/poetas que mantinham relações ou afinidades com as propostas dos surrealistas e que sofreram uma resistência programada ou uma obsolescência intencional por parte de nossa crítica e historiografia literárias.

${ }^{24}$ É o caso dos trabalhos de Robert Ponge, Surrealismo e Novo Mundo (1999) e a coletânea Aspectos do Surrealismo organizada por ele, Vanguardas latino-americanas (1995), de Jorge Schwartz, e A Aventura Surrealista (1995), de Sérgio Lima.

${ }^{25}$ Neste sentido pensamos no trabalho de Floriano Martins, O começo da busca: o surrealismo na poesia da América Latina, no qual o autor empreendeu uma antologia de algumas das expressões poéticas latinoamericanas mais originais recuperando boa parte da expansão surrealista hispano-americana. Com um trabalho de tradução impecável e por meio da reunião de informações epistolares e entrevistas, Floriano demonstra que houve sim manifestações surrealistas maduras tanto no Brasil quanto na América Latina e que estas não foram simples extensões tardias e periféricas do movimento francês.

${ }^{26}$ Ao indicar isso, não desconsideramos que essa situação também possa ser relativizada, como no caso de um crítico de orientação católica como Alceu Amoroso Lima, por exemplo, que desenvolveu boa parte de sua crítica sob essa perspectiva particularista e parcial. Para maiores informações sobre a crítica do autor é imprescindível a leitura de 1930: a crítica e o Modernismo (2000) de João Luiz Lafetá.
} 
1930. O crítico analisou e demonstrou as particularidades dessa passagem ao focar sua atenção, justamente, na crítica literária realizada no Brasil no decênio de 30 expondo certas conexões entre literatura e ideologia nela encenadas. A partir de um exame pormenorizado da perspectiva e do modus operandi de quatro importantes críticos da época, Agripino Grieco, Alceu Amoroso Lima (Tristão de Athayde), Mário de Andrade e Octavio de Faria, Lafetá extraiu conclusões precisas e determinantes acerca do contexto histórico-ideológico da década de 30, ao mesmo tempo em que ofereceu uma visão renovada e revigorada do próprio modernismo no Brasil. Lafetá realizou, assim, um verdadeiro desvendamento dos pressupostos desses críticos, indicando como os seus julgamentos foram afetados devido às opiniões religiosas, morais e políticas que eles possuíam.

Deste modo, ao perseguirmos certo caminho metodológico e epistemológico trilhado por Lafetá, pudemos revelar e concluir que o posicionamento crítico verificado na recepção muriliana, que legitima apenas parte de sua obra, aponta para uma concepção de arte poética à qual nossa crítica literária parece ter se inclinado a valorizar e a estimular. Trata-se de uma noção restrita de arte poética com pendores notadamente construtivistas. Este fato indica que desponta na crítica desses autores que analisamos uma resposta ao próprio horizonte de expectativas ${ }^{27}$ que os circundavam.

Não é nosso intuito invalidar e desqualificar as interpretações da poesia de Murilo aqui analisadas; pelo contrário, nosso trabalho deve muito a essas análises na medida em que elas contribuíram, sobremaneira, na divulgação da poesia de Murilo e no desvendamento de algumas de suas questões importantes. Estudando mais detidamente seus trabalhos, entretanto, percebemos que eles acabaram por eleger como mais importante um componente específico da poesia de Murilo, seu rigor construtivo, em detrimento de outros elementos tão caros à sua poesia como o surreal e o religioso, por exemplo. Cremos que ficará mais claro a partir dos nossos próximos capítulos que este elemento privilegiado por esses críticos não foi algo que o poeta tenha negligenciado em obras anteriores. Por isso, acreditamos que essa divisão qualitativa

\footnotetext{
${ }^{27}$ Utilizamos essa idéia de horizonte de expectativa no sentido com que a tomou Hans Robert Jauss em $A$ História da Literatura Como Provocação à Teoria Literária (1994) para designar todo um sistema de referências resultante de nossas experiências sociais acumuladas durante nossa formação e que trazemos conosco ao empreendermos a leitura de um texto. Tomamos o texto crítico, neste sentido, como uma leitura, embora atentos à sua dimensão interpretativa.
} 
não se sustenta. Esperamos demonstrar, no próximo capítulo, que ela é artificial e oculta aspectos decisivos e uma dinâmica peculiar da poesia de Murilo. 


\section{2- A SEGUNDA TENDÊNCIA CRÍTICA}

O conjunto de críticos que compõem o que estamos chamando aqui de segunda tendência acredita que, embora a obra de Murilo tenha passado por algumas mudanças significativas, o poeta não abandonou seus atributos anteriores, apenas os redimensionou. Dentre os críticos que sustentam este ponto de vista, podemos citar os seguintes nomes: Murilo Marcondes de Moura, Laís Corrêa de Araújo, Júlio Castañon Guimarães, Irene Miranda Franco, Joana Matos Frias e Sebastião Uchôa Leite.

Como foi dito, a primeira tendência acredita haver uma cisão na poesia de Murilo Mendes entre uma poesia de expressão mais ligada à idéia de inspiração e intuição poéticas, e uma poesia construtivista. Esta divisão guarda, como vimos, uma clara hierarquia entre estes momentos, representada pela eleição da dita "segunda fase" ou "fase construtivista" como a superior no interior da trajetória de Murilo.

O problema dessa perspectiva é que tende a considerar a imaginação e a razão como noções mutuamente opostas e excludentes. Como afirma Octavio Paz (1996) em Signos em Rotação: "razão e imaginação não são faculdades opostas: a segunda é o fundamento da primeira e o que permite perceber e julgar o homem.” (1996, p. 77).

Murilo Marcondes de Moura (1995) observa que essa tensão entre imaginação e fatura está disseminada no interior do próprio surrealismo que influenciou Murilo, bem como na arte moderna em geral. O crítico observa, ainda, como a tensão gerada por estes dois processos é fundamental para a criação poética muriliana:

\footnotetext{
A tensão entre arte como impulso imaginativo e construção formal (...) é absolutamente essencial em Murilo Mendes, e todas as discussões sobre a unidade de sua obra têm de contornar o difícil contraste, em sua trajetória, entre o predomínio de uma poética surrealista no início e o de uma poética construtivista (se ela de fato existiu) nos livros finais. O que se pode observar é que tal tensão existe no interior do próprio surrealismo e também no de toda a arte moderna. (MOURA, 1995, p. 30)
}

Além disso, como encontramos já no parágrafo introdutório do livro Murilo Mendes: a poesia como totalidade, de Murilo Marcondes de Moura (1995), é impossível reduzir a obra muriliana a formulações rígidas: "De uma poesia tão complexa como a de Murilo Mendes, dificilmente alguma fórmula, que propiciasse uma definição sintética, poderia resultar satisfatória.” (p.13). Também é essa a posição de Irene Miranda Franco (2002) em Murilo Mendes: pânico e flor: 
a divisão desta obra tão extensa e diversa em duas fases não pode ser estabelecida em termos definitivos. Nada do que se postula para cada uma das etapas da produção muriliana pode ser isolado de modo estanque. (FRANCO, 2002, p. 14)

Em Murilo Mendes: ensaio crítico, antologia, correspondência, um dos primeiros livros dedicado integralmente ao poeta publicado em 1972, Laís Corrêa de Araújo (2000) também aponta para a mesma direção ao afirmar que Murilo Mendes raramente tem obtido a compreensão da crítica literária brasileira.

Vimos no capítulo anterior que tanto Haroldo de Campos quanto Alfredo Bosi concordam que a poesia de Murilo sempre caminhou em direção a uma crescente concretização da linguagem poética. Para Haroldo, o ponto de chegada deste "mundo substantivo" em Murilo está representado por Tempo Espanhol (1959). Em prefácio a este livro, Júlio Castañon Guimarães (2001) afirma que não consiste esse momento de substantivação de uma ruptura no interior da obra muriliana, pois é possível alinhar alguns poemas de diversos livros anteriores de Murilo Mendes que apontam para esse caminho no meio do qual surge Tempo Espanhol.

Para Castañon, as mudanças sofridas na poesia muriliana não indicam que houve alguma espécie de interrupção na obra, pois sua "nova" poesia mais depurada e formal ou segundo Haroldo mais "concreta" -, já havia se manifestado gradualmente ao longo de livros anteriores. Neste ponto, o crítico cita dois poemas para exemplificação, sendo o primeiro deles "Oito Horas", de Os Quatro Elementos, livro que foi publicado conjuntamente com Mundo Enigma em 1945. Esse poema é composto apenas de uma estrofe de quatro versos, na qual a anáfora prevalece:

$$
\begin{aligned}
& \text { É a hora do vulcão, é a hora da mazurca, } \\
& \text { É a hora da Abissínia, é a hora do bordel, } \\
& \text { É a hora de Solange, é a hora do dentista. } \\
& \text { É a hora da explosão, é a hora do relógio } 28 .
\end{aligned}
$$

É grande a semelhança deste poema com alguns poemas do último livro de Murilo, Convergência, mais precisamente de sua segunda parte intitulada "Sintaxe". Aí predominam poemas nos quais Murilo realiza verdadeiros jogos de palavras baseados na homonímia e na paronímia. Embora a análise de Convergência esteja reservada para o nosso terceiro capítulo, vale a pena citar um poema de "Sintaxe". Assim, seja um

\footnotetext{
${ }^{28}$ Poesia Completa e Prosa, 1994, p. 278. Para evitar a repetição, as futuras referências a este livro serão feitas apenas por meio da abreviatura PCP, seguida do número da página.
} 
trecho do poema "O Silêncio" que, ainda que tenha diferenças, como a não utilização de verbos, por exemplo, guarda em comum com o poema anterior a utilização do recurso da anáfora:

$$
\begin{aligned}
& \text { O silêncio do papa. O silêncio da paina. } \\
& \text { O silêncio do silêncio. O silêncio do avô. } \\
& \text { O silêncio da bela. O silêncio da bola }
\end{aligned}
$$

Júlio Castañon demonstra, assim, que não é só através da persistência de vocábulos ligados à idéia de concretude, como observou Haroldo em seu inventário da concretização em Tempo Espanhol, que pode ser verificada a presença de um projeto de substantivação em Murilo. Segundo Castañon, essa recorrência estaria associada a toda uma poética que "toma corpo" naquele livro. O crítico recorda que Tempo Espanhol é publicado num momento de reavaliações e mudanças no plano mais amplo da poesia brasileira em geral, citando o caso de Drummond, que em 1951 havia publicado Claro Enigma, livro ligado àquele momento de classicização que já comentamos, e que em 1962 publica Lição de Coisas, fortemente marcado pela concisão aliada às experiências formais. Posteriormente, faremos uma observação a respeito de como certas questões permeiam tanto a obra de Murilo quanto a de Drummond, e de como estes elementos podem esclarecer alguns impasses na obra de ambos.

É importante deixar claro que boa parte dos críticos desta segunda tendência não ignora ou nega que tenha ocorrido na trajetória de Murilo um maior apuramento e condensação da linguagem poética. É o caso de Castañon, que acabamos de citar quando aponta poemas de livros anteriores de Murilo que já indicavam esta direção; e, também, de Laís Corrêa de Araújo, quando afirma que "se encontrava desde cedo em germinação na obra muriliana ou já era inerente à própria natureza de sua dicção o ensaio de uma concretização da palavra poética" (2000, p. 109). Laís considera característico de Murilo um "texto asséptico" no qual, por meio de permutações e seleções, o poeta selecionava para uso, justamente, vocábulos rijos e contundentes de sentido, o que evidenciava certo pendor racionalista e conceitualista. Por isso, afirma Laís que, "a nosso ver, esta insinuada 'cesura' não chega realmente a operar-se, nem como circunstância fortuita, nem como deliberada mudança de curso.” (2000, p. 119).

Essas considerações demonstram que essa poesia mais concretizada e substantiva não parece ser algo que tenha surgido de forma repentina na trajetória de

\footnotetext{
${ }^{29}$ PCP, p. 714.
} 
Murilo. Sob este ângulo, nada do que se postula como próprio a cada uma das aludidas duas fases apresenta-se unicamente nela, demonstrando assim que não há na poesia de Murilo momentos particulares que possam ser tomados isoladamente. Deste modo, é mesmo possível traçar uma espécie de ligação, no sentido de permanência de referenciais, desde o primeiro livro de Murilo, Poemas (1930), até o último, Convergência (1970), caminho apontado por Sebastião Uchôa Leite e cuja demonstração reservamos para nosso terceiro e último capítulo. Convém citar ainda Laís Corrêa de Araújo (2000), para quem o primeiro livro muriliano, além de já conter um alto grau de universalidade, também é uma espécie de:

microcosmo do universo lingüístico do poeta, que viria dimensionar-se em sua obra posterior, através da abertura da expressão, a qual se permitiria todas as liberdades do ritmo amplo, da desarticulação do vocabulário, da violação da sintaxe, enfim, num processo de dicção que logo se destacaria, pelo caráter individualizador e mesmo insólito, no quadro da poesia brasileira. (ARAÚJO, 2000, p. 70)

Acreditamos já ter apresentado as evidências acerca do motivo da não-aceitação integral da poesia de Murilo Mendes por parte da primeira tendência, ou seja, a desvalorização de suas primeiras produções poéticas devido tanto ao seu apelo religioso quanto ao influxo surrealista predominantes. Assim sendo, para a primeira tendência, um maior rendimento ou resultado estético da poesia muriliana estaria intrinsecamente vinculado a uma menor manifestação e influência destes dois domínios. Entretanto, estes processos são imprescindíveis para a poética muriliana; pode-se dizer que eles fundam e sustentam todo o seu projeto poético. Para esse fato, chamam-nos a atenção os críticos dessa segunda tendência de formas diversas e altamente plausíveis ao indicarem que tanto o catolicismo quanto o surrealismo encontram-se no cerne da poética muriliana e permaneceram nela até o final de sua trajetória.

É assim que, por exemplo, Irene Miranda Franco (2002), ao mencionar que boa parte da crítica também minimizou a importância da dimensão religiosa da poesia muriliana, mais especificamente em sua "segunda fase", destaca o fato de que a religião católica respaldou todo o projeto ético muriliano que "articula-se a seu fazer poético, desde as obras iniciais até as finais" (p. 14). Franco destaca ainda que "em toda a produção de Murilo convivem a religião católica, por um lado (...), e, por outro, uma poesia original e surpreendente" (p. 14). Para a estudiosa, a tensão gerada entre surrealismo e catolicismo na poesia muriliana jamais se resolve, sendo mesmo 
responsável pela singularidade dessa poesia que apresenta desconcertos e conflitos à primeira vista insolúveis devido, justamente, a essa junção aparentemente inconciliável entre surrealismo e catolicismo.

Neste ponto importa salientar o caráter singular desses dois elementos na poesia de Murilo a fim de demonstrar como eles conviveram unidos conferindo à sua poesia sua tônica dominante.

No que diz respeito ao surrealismo, é visível a sua influência na poesia de Murilo. Como destaca Júlio Castañon Guimarães (1993), “pode não haver surrealismo de forma ortodoxa, no sentido de adesão a uma escola, mas há claramente, no sentido de nítidas relações com um movimento de muitas fases e faces" (p. 31). Pode-se dizer que a aproximação de Murilo ao movimento francês não foi um mero acontecimento episódico motivado por um modismo histórico ou devido a razões circunstanciais, como temos discutido aqui. A nosso ver, este contato se deu porque o surrealismo se ligou a algo mais profundo que diz respeito ao cerne do pensamento e das preocupações poéticas de Murilo Mendes. É devido a isso que o surrealismo não será abandonado pelo poeta, sendo possível acompanhar a presença de elementos próprios ao surrealismo ao longo de toda a sua trajetória.

Contribuem para a comprovação dessa influência do surrealismo na obra muriliana algumas declarações do próprio poeta sobre o fascínio que o movimento exerceu sobre ele, as quais indicam os elementos caros ao movimento que ele teria incorporado em sua poesia:

\footnotetext{
Reconstituí também épocas distantes, a década de 1920, quando Ismael Nery, Mário Pedrosa, Aníbal Machado, eu e mais alguns poucos descobríamos no Rio o surrealismo. Para mim foi mesmo um coup de foudre. Claro que pude escapar da ortodoxia. Quem, de resto, conseguiria ser surrealista em regime full time? Nem o próprio Breton. Abracei o surrealismo à moda brasileira, tomando dele o que mais me interessava: além de muitos capítulos da cartilha inconformista, a criação de uma atmosfera poética baseada na acoplagem de elementos díspares. (MENDES, 1994, p. 1238)
}

Cabe mencionar ainda que os fundadores do surrealismo na França encaravam o movimento como, primordialmente, uma aventura do espírito humano e que, por isso, ultrapassava, largamente, os preceitos da arte. Nesse sentido, a poesia não é invenção verbal ou virtuosismo. Ao contrário, ela está indissociavelmente ligada à vida. Portanto, o movimento se pautava pela busca de atingir um estado anterior a qualquer moral e/ou cultura, no qual o homem poderia sentir-se em plenitude, completo, total. 
A este respeito, ressalte-se que vários nomes representativos dos estudos literários e conhecedores profundos do surrealismo destacam como característica do movimento essa convicção na unidade entre vida e poesia. Citemos, primeiramente, a voz de Maurice Nadeau (1985), que, de forma clara e breve, nos apresenta em sua História do Surrealismo a intenção do movimento em ser algo mais do que um escola literária:

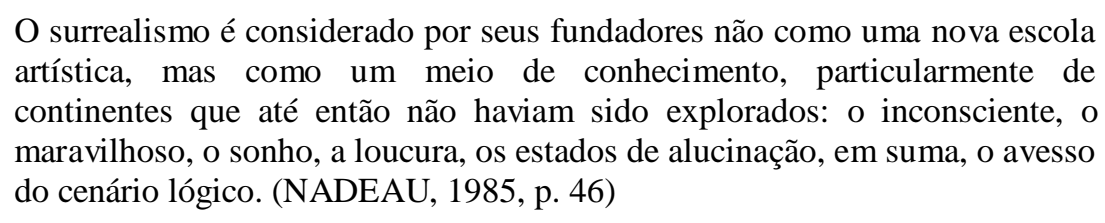

Outro crítico que ressalta as peculiaridades do surrealismo é Maurice Blanchot (1997), para quem o movimento foi uma tentativa pela qual o homem pretendeu "se descobrir como totalidade: totalidade inacabada e, no entanto, capaz, em um momento privilegiado (ou pelo simples fato de se ver inacabada), de se tomar como totalidade." (1997, p. 95).

Já Octavio Paz (1972) aponta que o desejo do surrealismo de apagar as fronteiras entre a arte e a vida não é algo novo, mas que foram novos os termos com que os surrealistas buscaram expressar isso. Era tamanha a crença, por parte dos surrealistas, no poder e na força da poesia que eles a levaram até as últimas consequências explorando aqueles terrenos destacados por Nadeau e até então vistos com muita desconfiança e assombro. Ainda segundo Octavio Paz: “o surrealismo é um movimento de liberação total, não uma escola poética. Via de reconquista da linguagem inocente e renovação do pacto primordial, a poesia é a escritura de fundação do homem" (1972, p. 224).

As inovações e as novas dimensões trazidas e proporcionadas pelo surrealismo possibilitaram a Murilo novos modos e maneiras de apreensão daquela totalidade perseguida pelo poeta. Vale recordar, aqui, a declaração realizada pelo próprio Murilo quando recebeu o Prêmio Internacional de Poesia Etna-Taormina em 1972: "Disse um discursinho breve, curto. Falei que só tive uma vocação neste mundo, a da poesia como uma totalidade" 30 .

Desse modo, o surrealismo tornou-se para o poeta, assim como o catolicismo, um local e um meio de observação e de indagação da natureza das coisas e do homem. Dizendo com Joana Matos Frias, para Murilo o surrealismo foi o "lugar onde se cruzam

\footnotetext{
${ }^{30}$ Murilo Mendes apud Murilo Marcondes de Moura, 1995, p. 13.
} 
uma série de vectores permanentes, transtemporais, que forma a estrutura profunda de sua obra e da sua poética" (2002, p. 34).

José Guilherme Merquior (1994), ao comentar sobre uma certa posição isolada de Murilo Mendes no interior do movimento modernista, destaca que esta se deveu, justamente, à absorção que o poeta realizou do surrealismo. O crítico ressalta que, se Drummond impregnou-se das lições de Mário de Andrade, Murilo soube assimilar, por própria conta e risco, as técnicas do surrealismo: "Aquilo mesmo que os três principais anarcovanguardistas, Oswald, Mário e Drummond, só incorporaram avulso - o surrealismo - Murilo adquiriu, por assim dizer, por atacado" (1994, p. 12).

Já no que diz respeito ao caráter religioso da poesia muriliana, convém apontar que se trata de um dado de caráter eminentemente biográfico que se tornou um referente intrínseco à obra e que, assim como o elemento surreal, permaneceu até o final de sua trajetória, como poderemos ver mais adiante. Um elemento importante que colabora no esclarecimento da questão, da adesão religiosa de Murilo e sua convivência com o surrealismo, é o fato de que o catolicismo do poeta é transgressor, eminentemente crítico e rebelde. Isso ocorre porque o poeta não se rende ao dogmatismo da doutrina católica.

Como observa Laís Corrêa de Araújo "a religiosidade do poeta não se conteria nos limites de um catecismo moderador e simplista" (2000, p. 80). O catolicismo, assim como o surrealismo, é concebido pelo poeta como uma via para a reflexão sobre o homem e o seu estar no mundo. Assim, é instrumento de uma perspectiva expansiva e universalista do homem, e é devido a isso que sua religiosidade, eminentemente híbrida (MOURA, 1995), não exclui o lado mundano e profano do mundo tão combatido pelo moralismo cristão, muito pelo contrário. O catolicismo muriliano é, por excelência, o local do pecado, pois nosso poeta é um "cristão, que só percebe a Verdade no corpo, a Presença no pecado, Deus no desejo.” (ARAÚJO, 2000, p. 145).

Não por acaso, José Guilherme Merquior (1994) menciona que o cristianismo de Murilo, além de agônico, é sacrílego, já que o poeta questiona alguns dos dogmas mais fundamentais do catolicismo em seus poemas. É assim que encontramos manifestações de extrema insolência, como o desafio lançado ao próprio Criador em "Poeta Nocaute":

Intimaremos Deus

A não repetir a piada da Criação

Salvaremos os que deviam nascer depois

E se Deus ficar firme

Anunciaremos à Virgem Maria 
Que nunca mais deverá nascer ninguém ${ }^{31}$.

Esse aspecto pode ser percebido num poema como "Igreja Mulher", de A poesia em pânico (1937), cujos primeiros versos dizem o seguinte:

\footnotetext{
A igreja toda em curvas avança para mim, Enlaçando-me com ternura - mas quer me asfixiar.

Com um braço me indica o seio e o paraíso,

Com outro braço me convoca para o inferno. ${ }^{32}$
}

Nesse poema, a postura insolente se manifesta na atribuição de características eróticas e femininas à igreja que é comparada em voluptuosidade a uma mulher toda em curvas. A propósito, convém citar o comentário de Laís Corrêa de que "a própria Igreja, quando se chama 'Esposa de Cristo', sacraliza um erotismo e mitifica o amor' (2000, p. 145). Nesse poema, a postura insolente se manifesta na atribuição de características eróticas e femininas à igreja que é comparada em voluptuosidade a uma mulher toda em curvas. Neste sentido, convém citar o comentário de Laís Corrêa de que "a própria Igreja, quando se chama 'Esposa de Cristo', sacraliza um erotismo e mitifica o amor" (2000, p. 145). A propósito, vale comentar que esta sacralização do amor erótico está presente na própria Bíblia num texto como o Cântico dos Cânticos, por exemplo. Embora seja verificada na tradição cristã uma tendência a uma compreensão espiritualizada deste texto, que tendeu a reforçar que o mesmo significaria o amor entre o povo eleito e Deus ou entre a Igreja e Cristo, o que constatamos quando o lemos é que se trata de um belo poema revezado entre as vozes dos amantes no qual se celebra o amor erótico. A inserção de semelhante texto no interior da Bíblia parece indicar, além de um desafio à própria moral cristã que a partir de um determinado momento passou a rechaçar e omitir qualquer reflexão sobre a manifestação da sexualidade/sensualidade, que Deus também criou o homem de forma sexuada, que além de espírito, ele também é corpo.

Assim, vemos que a alternativa eleita por Murilo, de aproximação com o sagrado pela via do corpo, ou seja, da aceitação do impulso carnal para a livre manifestação da experiência religiosa, não é um caminho de todo impossível ou inexistente só que, foi (e tem sido) censurado pela tradição e pela moral cristãs. Logo, essa peculiaridade de sua poesia, da união entre o espiritual e o carnal, essa

\footnotetext{
${ }^{31}$ PCP, p. 242.

${ }^{32}$ PCP, p. 303.
} 
religiosidade aparentemente profana suscitou muitas reações por parte da crítica literária, como, por exemplo, a censura de um crítico como Mário de Andrade. Em artigo sobre A poesia em pânico, Mário diante da surpresa, ou melhor dizendo, do desconforto experimentado no contato com essa poesia, além de censurá-la pela questão formal, condena seu aspecto religioso como um fator de mau gosto:

\begin{abstract}
a atitude desenvolta que o poeta usa nos seus poemas pra com a religião, além de um não raro mau gosto, desmoraliza as imagens permanentes, veste de modas temporárias as verdades que se querem eternas, fixa anacronicamente numa região do tempo e do espaço o Catolicismo, que se quer universal por definição. Neste sentido, o catolicismo de Murilo Mendes guarda a seiva de perigosas heresias ${ }^{33}$.
\end{abstract}

Esse claro juízo de valor de Mário, de resto, já discutido nas discussões engendradas no interior da recepção crítica de Murilo, ligaria o crítico à visão da primeira tendência crítica por nós aqui analisada, que diz respeito às condenações da existência de uma possível falta de preocupação formal e do apelo religioso da poesia muriliana.

Estas provocações religiosas praticadas por Murilo provavelmente se nutriam, em parte, da própria iconoclastia surrealista que, diga-se de passagem, embora mantivesse uma postura provocadora e agressiva diante da Igreja e outras instituições tradicionais, por outro lado valorizava a espiritualidade e creditava à palavra poética um verdadeiro poder místico, como um meio de conhecimento de locais até então inexplorados: o inconsciente, a loucura, o sonho. Vale a pena lembrar Murilo Marcondes de Moura ao indicar que "muitos textos surrealistas estão impregnados de um 'sentimento do infinito' próximo do religioso" (MOURA, 1995, p. 49). Segundo o crítico, é deste modo que encontramos muitos momentos da obra de Murilo que participam ou se encontram muito próximos daquele sentimento de "revelação profana" que Walter Benjamin considerou um dos traços mais relevantes do movimento surrealista $^{34}$.

Todavia, a postura agressiva dos surrealistas diante da instituição católica parece bem menos temerária do que a de nosso próprio poeta que abraçou o catolicismo, pois,

\footnotetext{
${ }^{33}$ Mário de Andrade. In: MENDES, PCP, 1994, p. 33-34.

34 Neste ponto Murilo Marcondes de Moura se refere ao texto de Walter Benjamin intitulado "O Surrealismo: o último instantâneo da inteligência européia" no qual o crítico ao refletir sobre o surrealismo ressalta a ocorrência no movimento dessa espécie de "iluminação profana, de inspiração materialista e antropológica". Walter Benjamin apud Murilo Marcondes de Moura, 1995, p. 49.
} 
como destaca José Guilherme Merquior (1994), enquanto a maior audácia de um Max Ernst consistia em pintar a Virgem aplicando palmadas ao Menino Jesus ${ }^{35}$, a ousadia de Murilo ia muito mais longe, beirando as vias da insolência já que o poeta criticava e questionava os dogmas fundamentais do cristianismo ${ }^{36}$.

Destaque-se que a convivência de surrealismo e catolicismo também só foi possível em Murilo devido à presença de uma espécie de sistema filosófico criada pelo amigo do poeta, o pintor Ismael Nery, e nomeada pelo próprio Murilo como Essencialismo. Esse sistema pregava a abstração espaço-temporal como um método de apreensão do mundo almejando um conhecimento total e uma plena unidade das coisas. Assim sendo, exaltava os aspectos concretos da realidade para remetê-la a algo abstratizante, valorizando, sobretudo, as imagens capazes de realizar esta passagem ${ }^{37}$. Como aponta Murilo Marcondes de Moura, o Essencialismo:

manifestava-se sempre como desejo utópico de totalidade e abrangência, e, com raríssimas exceções, nunca se mostrou de posse de qualquer verdade dogmática, consumindo-se, ao contrário, na exploração, que se sabia aproximativa, de outras possibilidades da experiência humana. (MOURA, 1995, p. 49)

Murilo conheceu Nery quando ocupou o cargo de arquivista no Ministério da Fazenda no Rio de Janeiro em 1921, local onde Nery já trabalhava como arquiteto e desenhista. Foi tão grande a influência pessoal e artística que Nery exerceu sob o jovem Murilo Mendes, é tamanha a importância da amizade travada entre ambos que, como ressalta Murilo Marcondes de Moura, "apenas por ela poderemos chegar ao centro das concepções que o poeta desenvolveu durante muitos anos, e que perduraram, embora com sensíveis transformações, até o final de sua vida." (1995, p. 43). O crítico se refere, neste ponto, tanto à conversão de Murilo ao catolicismo em 1934 quando do falecimento de Ismael Nery, quanto a uma maior aproximação com o movimento surrealista devido, também, à amizade do artista plástico. Nery, num primeiro momento,

\footnotetext{
${ }^{35}$ Merquior se refere ao quadro do pintor surrealista alemão, Max Ernst, intitulado "A Virgem espanca o Menino Jesus vigiada por três testemunhas: André Breton, Paul Éluard e o Próprio Pintor”, de 1926.

36 “....) enquanto a maior audácia de um Max Ernst consistia em pintar a Virgem aplicando palmadas ao Menino Jesus, e a de Aragon, em chamar a cruz cet horrible arbrisseau, a ousadia de Murilo questionava de cara os dogmas fundamentais." (MERQUIOR, 1994, p. 14)

37 O próprio Murilo resumiu de forma concisa o sistema essencialista: "na abstração do tempo e do espaço, na seleção e cultivo dos elementos essenciais à existência, na redução do tempo à unidade, na evolução sobre si mesmo para descoberta do próprio essencial, na representação das noções permanentes que darão à arte a universalidade”. (Murilo Mendes apud Júlio Castañon Guimarães, 1993, p. 24).
} 
foi o responsável pela atualização artística de Murilo sobre o surrealismo, pois quando o artista plástico viajou para a Europa em 1927, conheceu pessoalmente alguns artistas ligados ao movimento francês e o seu principal representante, André Breton, trazendo dessa viagem as mais frescas novidades sobre o surrealismo.

A junção entre catolicismo e surrealismo pode parecer, à primeira vista, uma contradição, mas, na poesia de Murilo, estes dois estados conviveram e garantiram à sua poesia uma singular riqueza de expressão. Este fato, inclusive, tornou-se um aspecto que despertou tanto a incompreensão quanto o preconceito em relação à poesia de Murilo por parte da crítica literária brasileira, como vimos. Todavia, é esta fusão, como indica Marcondes de Moura, um aspecto particular e único da obra muriliana: "Pode-se dizer que a fusão de pensamento religioso e vanguarda artística é o aspecto mais distintivo de sua obra. Muitos críticos do poeta expressaram sua perplexidade diante desse paradoxo." (1995, p. 49).

José Guilherme Merquior (1994) nos auxilia a compreender que esse paradoxo é apenas aparente, ao recordar o que já comentamos aqui, que o projeto do surrealismo não era em substância estético, mas, antes de tudo, de caráter existencial e que, por isso, "seu espírito se deixa entender melhor quando cotejado com as manifestações simbólicas das grandes religiões, não com estilos artísticos" (MERQUIOR, 1994, p. 12). Deste modo, não é difícil imaginar a conciliação dos “contrários" realizada por Murilo em relação ao catolicismo e ao surrealismo já que estes não estariam em posições tão opostas como se imagina.

É possível, também, traçar algumas similaridades entre posturas, a dos surrealistas e as idéias essencialistas, conforme ressalta Murilo Marcondes de Moura (1995). A primeira diz respeito à composição da imagética desconcertante, tão valorizada pelos surrealistas e praticada, também, por nossos essencialistas, Murilo e Nery, este, especialmente em seus quadros. Breton, no Manifesto do Surrealismo, lançado em 1924, indica a importância das imagens "que emprestam o mais naturalmente possível ao abstrato a máscara do concreto" ${ }^{38}$. A segunda proposta coincidente entre os dois sistemas é a da busca pela totalidade. Como vimos, os surrealistas almejavam atingir uma totalidade através da arte e, para tal, usaram e abusaram da técnica da combinação de contrários já que, conforme aponta André Breton no mesmo Manifesto,

\footnotetext{
${ }^{38}$ André Breton apud Murilo Marcondes de Moura, 1995, p. 21.
} 
Tudo leva a crer que existe um certo ponto do espírito do qual a vida e a morte, o real e o imaginário, o passado e o futuro, o comunicável e o incomunicável, o alto e o baixo deixam de ser percebidos contraditoriamente. Ora, é em vão que se buscaria na atividade surrealista um outro móvel que a esperança de determinação desse ponto ${ }^{39}$.

No que diz respeito à principal ressalva da primeira tendência crítica em relação à poesia de Murilo, seu descaso formal, se atentarmos bem para a trajetória do poeta, verificaremos que ele sempre manteve grande preocupação com a forma poética. A prova disto é que, mesmo aderindo a procedimentos e certa orientação do surrealismo, nunca adotou um dos principais métodos do movimento que foi a escrita automática, fato indicado por Murilo Marcondes de Moura (1995) e por Joana Matos Frias (2002) que indica a similaridade da poesia de Murilo com a de Mallarmé já que ambos consideram o trabalho poético essencial:

\begin{abstract}
Ainda que não se refira, como faz o autor de Igitur, à sua poesia como a um laboratório, e ainda que não considere a inspiração como a marca de um condenável subjetividade, o certo é que MM acompanha Mallarmé ao considerar o trabalho poético essencial. É por esta razão que, apesar da sua declarada afinidade com o Surrealismo, não se une a um dos princípios nucleares do movimento, a escrita automática. (FRIAS, 2002, p. 19)
\end{abstract}

José Guilherme Merquior (1994) também observou esta não-adesão de Murilo ao método da escrita automática dos surrealistas ao indicar que o poeta destinou sua fidelidade, sobretudo, à carga utópica do surrealismo e não aos seus preceitos, normas e/ou métodos. Para o crítico, a absorção do surrealismo por parte de Murilo foi, paradoxalmente, uma disciplina e um rigor, justamente porque o poeta fundiu de forma única o surrealismo e o rigor formal:

Do surrealismo é imperativo dizer-se que, para Murilo, ele foi principalmente (por paradoxal que pareça) uma disciplina, um rigor - uma ascese poética. Tanto mais gratuita soa, por isso, a longa reticência com que foi, até duas décadas atrás, recebida a natureza estilhaçada e fragmentária do seu verso deliberadamente imelódico e inarmônico. Esse fanático de Mozart exilou de quase todos os seus livros o cursivo da meolopéia lírica (...). (MERQUIOR, 1994, p. 15)

É por isso que Luciana Stegagno-Picchio acertava quando, ao comentar sobre o livro A Poesia em Pânico, descreveu o livro e a poesia de Murilo como "um dos poucos

\footnotetext{
${ }^{39}$ André Breton apud Murilo Marcondes de Moura, 1995, p. 40-41.
} 
exemplos daquele 'surrealismo lúcido' que, num certo sentido, separa a experiência modernista brasileira da francesa e em geral da hispano-americana" 40.

No entanto, como vimos com Moura (1995), a tensão dialética entre expressão e construção também existiu no interior do próprio movimento surrealista. O exercício da poesia por parte dos surrealistas consistiria numa espécie de entrega velada/resguardada, já que muitos dos textos tidos como produto da escrita automática aparentam serem mais exercícios meditados de composição, o que foge à ideia de um puro automatismo psíquico, filiado a uma estética do impulso e do inacabado.

Com todas as considerações que temos visto até aqui, as quais, espera-se, poderemos reforçar em nosso terceiro capítulo, quando analisaremos Convergência, é possível distinguir claramente que essa poesia mais construtivista eleita pela primeira tendência como a melhor produção de Murilo não foi algo que sucedeu de modo abrupto em sua trajetória. É óbvio que algumas mudanças, redefinições e redimensionamentos ocorreram, pois a atividade poética de Murilo, eminentemente aberta e inconclusa, esteve sempre envolvida num constante devir. Entretanto, parece não ter ocorrido, em sua poesia, o abandono de certas noções e referências que sempre orientaram sua poesia e as quais, devido a sua importância e abrangência, foram fixadas numa espécie de base poética imutável.

Joana Matos Frias (2002), em O Erro de Hamlet: poesia e dialética em Murilo Mendes observa que a obra muriliana sempre esteve alicerçada sob o signo da mudança. Deste modo, este seria mais um dos paradoxos da poesia de Murilo, só o que não muda é a sua inclinação para uma mudança contínua:

o texto muriliano vive de uma dramática experiência de mudança (...) esta experiência pressupõe uma constante modificação imanente, que dimana de uma tensão contraditória própria da metamorfose. Neste sentido, a obra poética de Murilo Mendes é declarada e assumidamente proteiforme. (FRIAS, 2002, p.13)

Ao lançar mão deste termo, "proteiforme", a autora indica ter-lhe recolhido em Jorge de Sena, em "Notas sobre Afonso Duarte": "uma poesia proteiforme [...] refaz-se constantemente sobre um fundo permanente indiviso e homogéneo, que sobrevive sempre às metamorfoses do poeta sem nelas participar". A constância da metamorfose muriliana é, então, duplamente paradoxal, pois não são simples mudanças ou passagens de um estado a outro; mas são marcas de um sujeito poético que permanece na medida

\footnotetext{
${ }^{40}$ Luciana Stegagno-Picchio. In: MENDES, Murilo. PCP, 1994, p. 1639.
} 
em que se transfigura como indica Frias. Segundo a autora, a obra de Murilo, escrita ao longo de mais de quarenta anos, é determinada por múltiplos centros e vários focos de energia que emanaram de sua "heterogênese". Para a autora, este termo traduz melhor os múltiplos caminhos existentes na gênese da poesia muriliana:

\begin{abstract}
escrita ao longo de mais de quarenta anos, a obra de Murilo Mendes é determinada por múltiplos centros, por vários focos de energia que emanam da sua heterogênese. Tendo em conta que, na acepção biológica originária, o termo heterogênese aponta para a coexistência de dois processos distintos de reprodução na evolução de um indivíduo, o conceito emerge da irradiação sêmica que prefigura: por comportar no seu prefixo os traços de diferença, irregularidade, variedade tipológica, desigualdade, sobreposição, polimorfismo ou diferenciação morfológica, apresenta-se como o lexema apropriado para assinalar os modos de convivência de vários processos literários na gênese e evolução da poesia de Murilo. (FRIAS, 2002, p. 14-15)
\end{abstract}

Para Frias, essa heterogênese de Murilo foi o que lhe permitiu percorrer as várias tendências da poesia do século XX "metamorfoseando a sua obra poética e assentando-a em pilares de materiais muito diversos" (p. 21). Isso permitiu, segundo a estudiosa,que Murilo assumisse em simultâneo a síntese dialética das duas grandes linhas da modernidade poética inaugurada por Mallarmé e Rimbaud: “com Rimbaud, uma poesia alógica e de forma livre, com Mallarmé, uma poesia do intelecto e de forma muito rigorosa" (p. 21).

Conforme aponta Antonio Candido (1999), só o pressuposto da metamorfose explica a liberdade com que Murilo Mendes "combina os elementos mais díspares para gerar uma fascinante realidade além da realidade, e ao mesmo tempo aderente a ela" (p. 76). Esse comentário de Candido trata a metamorfose mais particularmente no que concerne à poesia visionária de Murilo, impregnada pelo influxo surrealista, já que, para o crítico, deriva daí sua facilidade em criar universos insólitos e surpreendentes nos quais o mero cotidiano pode tornar-se/metamorfosear-se em algo suprarreal ou mesmo miraculoso e/ou sublime. Todavia, ao lidarmos com o termo 'metamorfose' na obra muriliana, podemos considerá-lo, não só sob o ponto de vista estritamente formal, mas também num sentido mais amplo, que engloba essa capacidade de Murilo em renovar constantemente sua produção poética sem, entretanto, abandonar o que já lhe era 
intrínseco. Vale recordar que Murilo intitulou um dos seus livros justamente As Metamorfoses (1944) ${ }^{41}$.

Para Joana Frias, este caráter de mutabilidade da poética de Murilo seria a primeira manifestação de sua modernidade. A autora cita o crítico Octavio Paz (1993), que atesta que a época moderna foi a primeira a exaltar a mudança e a convertê-la em seu fundamento. Para Octavio Paz, como uma das principais características da modernidade teríamos a negação de todos os princípios, porque a mudança perpétua seria a única diretriz moderna. Devido a isso, o moderno é caracterizado por sua heterogeneidade: "tradição do heterogêneo, a modernidade está condenada à pluralidade" (PAZ, 1984, p. 18).

Essa consideração nos interessa sobremaneira porque a poesia de Murilo está marcada por essa dinâmica peculiar. De um lado, a constante tendência à mutação e a diversidade/multiplicidade que daí deriva. Como observou Joana Frias (2002), retomando Octavio Paz: "aceleração e multiplicação: as mudanças estéticas deixam de coincidir com o passo das gerações e ocorrem dentro da vida de um artista" ${ }^{42}$.

Outro autor que ressalta essa heterogeneidade das poéticas modernas é Alfonso Berardinelli (2007), que, ao comentar sobre a tendência da linguagem poética moderna de fugir a toda contaminação por outros referenciais e gêneros, salienta que nada poderia ser mais paradoxal, já que a lírica moderna frequentemente "elimina o sujeito monologante e o distribui numa pluralidade de vozes, 'descentra' o eu, engloba a prosa e todo tipo de material inerte, joga com o heterogêneo e o desafia." (p. 143).

Alguns fatos podem esclarecer de forma bem clara esta heterogeneidade da poesia muriliana. O primeiro deles está representado pela absorção que Murilo realizou do surrealismo e a convivência deste reflexo com a ressonância de sua adesão religiosa. Um outro fato é que Murilo ao longo de sua trajetória se dedicou tanto à poesia quanto à prosa. Esse interesse pelas duas formas de escrita não se deu de forma isolada ou exclusiva, ao contrário, ocorreu uma espécie de interpenetração entre ambas. Indicamos

\footnotetext{
${ }^{41}$ Em relação a esse livro, Daniela Neves (2001) destacou um conjunto de relações que se podem estabelecer a partir do diálogo entre ele e As metamorfoses de Ovídio, como, por exemplo, uma predominância de imagens do princípio e do fim do mundo e a representação da morte. Entretanto, não podemos nos esquecer de que a época de produção desse volume, entre os anos de 1938 a 1941, foram os primeiros anos da Segunda Guerra Mundial. A escolha por imagens representativas do caos, portanto, também refletem, em alguma medida, as aflições vivenciadas por Murilo naquele período. No entanto, essa repercussão ainda não encontrará nesse livro sua representação mais adensada, o que ocorrerá, segundo Luciana Stegagno-Picchio e Murilo Marcondes de Moura, num livro posterior, que é Poesia liberdade (1947), visto, por eles, como o livro muriliano mais comprometido com a realidade imediata da guerra.

${ }^{42}$ Octavio Paz apud Joana Matos Frias, 2002, p. 16.
} 
isso ao pensar na prosa poética de Murilo que predomina no final de sua trajetória já que a produção em prosa é esmagadora. São, no total, onze volumes, sendo a maior parte composta de livros inéditos que só vieram a lume quando da publicação de sua obra completa com organização de Luciana Stegagno-Picchio em 1994, a saber: Carta Geográfica (1965-1967), Espaço Espanhol (1966-1969), Janelas Verdes (1970), Retratos-relâmpagos (2a série composta entre 1973 e 1974), Conversa Portátil (19711974), A Invenção do finito (1960-1970), O Sinal de Deus (1936), Quatro Textos Evangélicos (1984). Dos quatro últimos livros murilianos publicados ainda em vida, só Convergência (1970) é de poesia, ao passo que os outros, de prosa são, respectivamente: A Idade do Serrote (1968), Poliedro (1972) e a primeira série de Retratos-relâmpago, de 1973. Há ainda, na trajetória de Murilo, um volume especial, de caráter eminentemente ambíguo e que, portanto, não poderíamos isolá-lo como pertencente a um ou outro gênero, que é o livro de aforismos $O$ discípulo de Emaús, de 1946, considerado por Luciana Stegagno-Picchio como verdadeira 'profissão estética ${ }^{43}$.

É preponderante, dentre os seus livros de prosa, textos que incursionam pela literatura dita de viagem, como Janelas Verdes, Espaço Espanhol e Carta Geográfica. Observa-se, com Castañon (1993), que os locais geográficos eleitos por Murilo são espaços onde predominam elementos culturais. Essa temática geográfico-cultural é um dado relevante também nos livros de poesias. Recorde-se que o primeiro livro de Murilo dedicado a um espaço geográfico abordado em seus elementos culturais é o volume de poemas, Contemplação de Ouro Preto, lançado em $1954^{44}$.

Júlio Castañon (1993) destaca duas características dessa literatura de viagem produzida por Murilo. O primeiro é o fato de que raramente há alguma referência à viagem propriamente dita: tanto os deslocamentos, os percursos efetuados e as motivações para realizá-los nunca são referidos. Outro fato interessante é que os espaços descritos nos textos murilianos são, basicamente, os da cidade. Todavia, segundo Castañon, a cidade muriliana, diferentemente da baudelairiana, não aparece povoada por multidões desoladas; sua descrição é sempre voltada para o plano cultural,

\footnotetext{
${ }^{43}$ Luciana Stegagno-Picchio apud Murilo Marcondes de Moura, 1995, p.74. O crítico indica que essa tipo de leitura é adequada e que ele próprio incorpora esta visão a respeito deste livro, mas que, no entanto, isso originou algumas deformações, basicamente a de ler alguns fragmentos só pelo ponto de vista estético desprezando o evidente estrato ideológico, notadamente essencialista que subjaz a eles.

${ }^{44}$ Outros volumes que podem ser vistos sob essa perspectiva são Tempo Espanhol e Siciliana, os quais já trazem nos títulos a indicação de que foram escritos a partir de um local geográfico específico. Nesses livros Murilo homenageia e faz referências a toda uma tradição cultural. No entanto, as cidades e os espaços físicos são quase sempre suscitados devido ao forte apelo cultural e estético que neles reside.
} 
para os monumentos arquitetônicos, para as obras de arte e as literárias, para os artistas e escritores que povoaram ou passaram por aquela cidade. Castañon destaca também que a cidade com seu repertório cultural e seus costumes não está presente somente nestes textos, mas já aparece como imagem importante no primeiro livro de Murilo, Poemas. Desse livro, o crítico extrai o exemplo do poema "Noite carioca", do qual citamos um trecho:

\footnotetext{
Noite da cidade de São Sebastião do Rio de Janeiro tão gostosa que os estadistas europeus lamentam ter conhecido tão tarde. Casais grudados nos portões jasmineiros...

A baía da Guanabara, diferente das outras baías, é camarada, recebe na sala de visita todos os navios do mundo. ${ }^{45}$
}

O crítico ainda destaca que não só neste primeiro livro, mas também em outros do início da produção poética muriliana e que estariam mais ligados à vertente surrealista, encontramos fragmentos da cidade que participam como componentes importantes das imagens. Castañon aponta que, mesmo em textos murilianos que não se encaixam nessa literatura de viagem, como Retratos-relâmpago, o que fica implícito é o trânsito do poeta, um deslocamento que não se efetiva só entre países e locais que descreveu, mas também através das línguas nas quais o poeta escreveu. É frequente a utilização por parte de Murilo de palavras de outras línguas, que invadem os seus textos, principalmente, os do final de sua trajetória para o que colaborou, sem dúvida, o fato de ter residido na Itália a partir de 1957, só voltando ao Brasil esporadicamente.

O modo de aparição de outras línguas na poesia de Murilo ocorre de variadas formas e em muitos momentos, algumas vezes elas irrompem na forma de uma citação da frase ou versos de outros escritores e/ou artistas, como indica Castañon, que estudou o recurso da citação por parte de Murilo; outras vezes alguma palavra ou expressão estrangeira aparece de forma integrada ao texto muriliano. Elas surgem, também, e muitas vezes, de forma aportuguesada. Veremos exemplos disso em nosso próximo capítulo, ao analisarmos alguns poemas de Convergência. Destaque-se ainda que Murilo deixou inéditos dois livros totalmente produzidos em outras línguas, volumes que só foram publicados na edição de sua obra completa. Um deles é o livro de poemas em italiano, Ipotesi, composto em sua maior parte em 1968, como indica Luciana Stegagno-Picchio em nota ao livro; o outro é Papiers, com textos em francês, língua

\footnotetext{
${ }^{45}$ PCP, p. 96.
} 
que desde menino Murilo se dedicava a estudar; a maior parte dos textos deste livro diz respeito ou alude a diversos escritores, pintores, músicos etc.

Considerando todos esses aspectos, Castañon (1993) propõe que se encare a obra muriliana dentro de uma perspectiva de interação globalizante, que inclua esses deslocamentos e cruzamentos, seja entre a poesia e a prosa, entre outras línguas, ou na referência permanente aos diferentes tipos de linguagens, como as artes plásticas e a música, por exemplo, com as quais o poeta manteve um diálogo constante.

Ainda no que diz respeito à aproximação entre prosa e poesia que ocorre na obra muriliana, percebe-se que, se, por um lado, a prosa se torna poética, por outro, muitos de seus poemas revelam certas incursões pelo domínio da prosa ${ }^{46}$. Pode-se dizer, com Castañon (2001), que ocorre um verdadeiro compartilhamento de técnicas e procedimentos entre os dois gêneros já que algumas das conquistas da poesia muriliana estão presentes em seus textos de prosa. Tal é o caso do livro de memórias, A Idade do Serrote (1968), no qual encontramos procedimentos similares aos utilizados nos livros de poemas da mesma época, como, por exemplo, a utilização de anáforas e paranomásias que ocorrem em demasia em Convergência, por exemplo. Citemos, respectivamente, um trecho de A Idade do Serrote e um poema de Convergência a fim de que se perceba a semelhança estrutural e a utilização comum de procedimentos e técnicas tanto na prosa quanto na poesia murilianas:

\footnotetext{
As têmporas de Antonieta. As têmporas da begônia. tempo $^{47}$.

As válvulas da valva. As válvulas da vulva.

As válvulas da viola. As válvulas do vulgo.

As válvulas do povo. As válvulas do polvo.

As válvulas da valsa. As válvulas da viúva ${ }^{48}$.
}

As têmporas da romã, as têmporas da maçã, as têmporas da hortelã. As pitangas temporãs. O tempo temporão. O tempo-será. As têmporas do

Para Antonio Candido (1989), o que predomina nos textos de Murilo é uma total atmosfera poética já que, segundo o crítico, Murilo é o poeta "mais radicalmente poeta da literatura brasileira, na medida em que praticamente nunca escreveu senão poesia, mesmo quando escrevia sob a aparência de prosa" (p. 56). Para Candido, a prosa de

\footnotetext{
${ }^{46}$ Veremos isso mais adiante quando efetuarmos nossa análise sobre Convergência.

${ }^{47}$ PCP, p. 897.

${ }^{48}$ PCP, p. 708.
} 
Murilo em A Idade do Serrote, por exemplo, é de tal maneira transfiguradora "que nós nos sentimos dentro da poesia, como um primeiro fator que alarga o restrito elemento particular da recordação pessoal” (1989, p. 56). O crítico conclui, assim, que Murilo sempre exerceu a sua capacidade de debate e reflexão, que era enorme, de modo eminentemente poético. A este respeito, convém mencionar o fato de que o poeta exerceu por um bom tempo a atividade de crítico de artes plásticas, produzindo textos nos quais não se nota de imediato uma intenção crítico-avaliativa devido, justamente, à dicção poética dominante nesses textos. Essa especificidade levou o crítico de arte italiano, Giulio Carlo Argan, a considerar que "para Murilo Mendes a crítica de arte era um gênero literário, um capítulo do seu trabalho poético" ${ }^{49}$.

\subsection{A perspectiva de Sebastião Uchôa Leite}

A partir de agora analisaremos mais detalhadamente a perspectiva de Sebastião Uchôa Leite (2003) por considerarmos que esta se apresenta como uma das interpretações que mais alcança a complexidade da poesia de Murilo sem propor formulações rígidas ou hierarquizá-la. É o que revela já o próprio título de seu texto, “ $A$ meta múltipla de Murilo Mendes", em que o crítico aponta para a multiplicidade da poesia muriliana.

Ao iniciar seu artigo, Sebastião Uchôa Leite indica que elaborar um juízo sobre a totalidade da obra muriliana é algo difícil, pois ela "abarca direções múltiplas, deixa no ar contradições e indagações, e no final o autor parece mudar radicalmente sua orientação estética” (p. 62). Entretanto, avaliando-se a obra mais atentamente, afirma o crítico que "faces esquecidas reemergem, como se houvesse uma ânsia de retorno às origens, e, vendo-se de perto, as mudanças não são radicais ao ponto de haver renegação da obra anterior" (p. 62). O crítico salienta ainda que, estruturalmente, Murilo permanece o mesmo desde seu primeiro livro até o último publicado em vida no Brasil, Convergência (1970), indicando que neste "repercutem ecos da intensa aventura poética iniciada em Poemas em 1930” (p. 62).

\footnotetext{
${ }^{49}$ Giulio Carlo Argan apud Júlio Castañon Guimarães, p. 86.
} 
Outros críticos pertencentes ao que estamos chamando aqui de segunda tendência crítica salientam a interligação das "fases" murilianas e a permanência de certos referenciais, servindo-se como exemplo, justamente, do último livro de Murilo, Convergência, como é o caso de Laís Corrêa de Araújo, que afirma: "o leitor mais atento da obra muriliana constatará no livro (...) a 'convergência' inevitável de toda uma experiência de vida e criação que se desdobrou sob o signo da liberdade" (ARAÚJO, 2000, p. 127).

Para Uchôa Leite, a divisão da obra muriliana em duas fases, sendo uma de "melhor" qualidade que a outra, negaria um aspecto decisivo de sua poética: a retomada e a reelaboração, em sua "segunda fase", de procedimentos e temas da "primeira", o diálogo intertextual entre todos os seus livros. O crítico ressalta que a multiplicidade da poética de Murilo Mendes é a sua característica primordial e que esta diversidade é verificada desde o seu primeiro livro, que lança as pedras fundamentais de uma "trilha múltipla", com várias direções, entre as quais três são básicas. São elas, segundo Uchôa Leite: o poeta crítico-irônico, o poeta voltado para a cotidianidade e o poeta reflexivo. De acordo com Uchôa Leite, estas diretrizes acompanharão a obra de Murilo até o fim, ainda que com alguma mudança, como é o caso do tom crítico-irônico que, segundo Uchôa Leite, sofreu uma transformação assumindo uma dicção mais filosófica do que a meramente sarcástica que caracterizou um livro como História do Brasil (1932).

A propósito, Murilo, quando do lançamento de sua antologia Poesias (1959), excluiu aquele volume justificando que sua inserção desequilibraria o volume. Consideramos que a rejeição de História do Brasil deve-se justamente a esta mudança de caráter do tom irônico de sua obra ${ }^{50}$. Segundo Uchôa Leite, a partir de $O$ Visionário (1941) as duas outras direções, a materialidade cotidiana e a reflexão sobre os processos vitais, se unem na poesia de Murilo.

Para Uchôa Leite, existe uma espécie de "estética de base", algo como o fundo comum que subjaz à sua poesia, apesar das transformações, de que fala Joana Matos Frias como vimo. Esta "estética de base" foi instituída, segundo Uchôa Leite, principalmente, pelos quatro primeiros livros de Murilo, quais sejam: Poemas (1930), A Poesia em Pânico (1937), As Metamorfoses (1944), Os Quatro Elementos (1945) e Mundo Enigma (1945). Segundo o crítico, esta estética teria como principais características: o predomínio do processo de montagem/desmontagem - o que confere à

\footnotetext{
${ }^{50}$ Voltaremos a essa questão em nosso terceiro capítulo.
} 
poesia muriliana, além do seu caráter altamente plástico, a idéia de corte, movimento e ritmo; o processo de construção antitético que caracteriza sua poesia como um jogo de antíteses; e, por último, certa dissonância contrastante no u so de elementos lexicais ${ }^{51}$.

Uchôa Leite observa que, embora exista uma espécie de "lenda de intuição poética" que sempre cercou a obra de Murilo desde o seu início, ela é, justamente, uma lenda, uma vez que a preocupação com a forma não foi algo que o poeta negligenciou em nenhum momento. Com isso concordam os críticos dessa tendência, como já aludimos.

Quanto aos críticos que julgam o contrário, que Murilo teria traído a si mesmo por "abandonar" sua poesia anterior, altamente metafórica e paradoxal e ter se rendido a uma poesia excessivamente denotativa, Uchôa argumenta que essa traição inexistiu:

Essa crítica [...] privilegia como em antigas noções idealistas e românticas, um roteiro "adequado" para o que é e o que não é poético. Essa traição inexiste, na verdade, no caso particular de Murilo Mendes. Alguns de seus processos talvez tenham mudado, mas a inflexão e a tonalidade continuaram as mesmas. (LEITE, 2003, p. 71)

Para o crítico, o último livro de Murilo, Convergência "não seria mais do que uma consequência lógico-formal de Tempo Espanhol (1959)" (p. 69). Nesse livro, como já apontou Haroldo de Campos, há um uso recorrente de termos ligados semanticamente à idéia de concretude. Segundo Uchôa Leite, estes elementos ajudaram Murilo a empreender construção de um perfil claro e conciso da civilização espanhola com o intuito de "construir um ideograma daquela civilização".

Uchôa Leite realiza um apontamento muito pertinente a respeito dos dois livros anteriores a Tempo Espanhol e que pode ser estendido a este. Para o crítico, em Parábola (1952) e Siciliana (1955) percebe-se "uma busca de concentração extrema" e de "uma isomorfia tema/linguagem", ou seja, há uma correspondência coerente entre a própria linguagem e os temas sobre os quais ela se debruça. Essa observação é aplicável a Tempo Espanhol, pois, segundo Uchôa Leite, busca-se no livro "recuperar nos termos estritamente materiais da linguagem verbal, o substrato do espírito espanhol” (p. 69).

Para o crítico, os traços e procedimentos representados nesta "estética de base" muriliana indicariam "a permanente preocupação formal na poesia de Murilo, que, por

\footnotetext{
${ }^{51}$ Lembramos que este último aspecto citado foi percebido e analisado por críticos pertencentes à primeira tendência, tratando-se da discordia concors aludida por Luiz Costa Lima e Haroldo de Campos.
} 
trás do seu singular 'desconstrucionismo', poderia parecer a construção deliberada de uma des-ordem, mas guardou sempre uma secreta ânsia de ordem em todas as suas fases” (p. 65). Na visão do crítico, haveria nessa poesia uma espécie de "desconstrutivismo construtivo", sendo que este paradoxo não seria de se espantar visto que Murilo sempre possuiu uma tendência dualista, que pode ser verificada em poemas ao longo de toda a sua obra. Laís Corrêa de Araújo (2000) menciona algo muito similar ao afirmar que toda a poesia muriliana constroi-se a partir de dicotomias de natureza filosófica e linguística. A autora chega a tomar um verso muriliano, "as colunas da ordem e da desordem", do poema "Dois Lados", como uma síntese definidora de toda a sua obra poética. De acordo com Laís, nessa dialética fundamental é que se funda a concepção muriliana do homem e do mundo e "a própria textura de sua linguagem, na inter-relação do real, do metafísico e do estético" (ARAÚJO, 2000, p. 141). A autora salienta que a "desordem” é uma atitude intrínseca, filosófica em Murilo, sendo "o princípio de incerteza que rege o ineditismo da mensagem muriliana e mantém, constituindo-se em Ordem, a sua linguagem ao nível exemplar da informação original.” (p. 147).

Deste modo, como já viemos salientando e esperamos que fique mais claro em nosso próximo capítulo, Murilo sempre foi dotado de uma consciência construtiva que, no entanto, não o impediu de abrir sua poesia para o terreno da imaginação.

Acreditamos que a proposta de se considerar a obra de Murilo sob o ponto de vista de um "desconstrutivismo construtivo" seja uma das maiores contribuições de Uchôa Leite, pois elimina a divisão entre uma poesia de construção e de inspiração poéticas e a possível superioridade de um ou outro desses elementos. Uchôa Leite demonstra que essa fusão paradoxal é fundamental para a poesia de Murilo, algo muito similar ao que indica a crítica portuguesa Joana Matos Frias (2002) ao afirmar que Murilo assumiu em simultâneo a síntese dialética resultante das linhas da Modernidade inaugurada pelos dois poetas franceses aos quais já aludimos aqui: Rimbaud e Mallarmé. É assim que, segundo Joana (2002), a poesia de Murilo inviabiliza as antinomias disseminadas pela crítica literária da poesia moderna que sempre tendeu a caracterizar esses caminhos, o da construção e o da inspiração, de forma antitética. Esse é o caso da distinção postulada por Hugo Friedrich em A Estrutura da Lírica Moderna (1978) entre a fête de l'intellect valériana e a faillite ou débâcle de l'intelect de Breton e 
Éluard; ou ainda, da separação efetuada por Marcel Raymond em De Baudelaire ao Surrealismo (1997) entre artistas e videntes.

Embora boa parte dos críticos aqui citados ressalte a diversidade e heterogeneidade inerentes à poesia de Murilo, acreditamos também que, ao apontar qual teria sido a trilha múltipla percorrida pelo poeta, Uchôa Leite nos oferece, de forma clara e precisa, a possibilidade de concluir que, ainda que tenha havido mudanças ao longo de sua trajetória poética, essas não chegaram a modificar as constantes que sempre retornam em sua poesia. Um dos caminhos que também nos permite avaliar isso também foi indicado por Uchôa Leite e estaria no "diálogo intertextual" empreendido por Murilo Mendes em Convergência. Aí podem ser identificados certos referenciais formais e temáticos orientadores da poética muriliana desde o seu início - aquela “estética de base" referida pelo crítico - e que garantem ao poeta uma coerência em seu projeto estético. Nesse sentido, que o título do livro muriliano traga, justamente, um vocábulo que porta como carga semântica a ideia de ponto em que objetos ou elementos tendem a se encontrar, não parece um fato nada casual.

De fato, Murilo é um poeta que sempre apresentou uma grande receptividade para todas as possibilidades de manifestação da pluralidade da vida e do espírito, com tudo que isso abarca de dissonâncias, contradições e convergências. Assim, pôde empreender a tarefa de verter toda essa multiplicidade visceral em matéria poética. Essa abertura e receptividade vêm indicada num verso de "Novíssimo Orfeu" e que poderia ser tomado como um princípio norteador de boa parte de seus poemas: "Vou onde a poesia me chama" 52 .

Devido a este momento especial representado por Convergência e por acreditarmos, como indicam os críticos dessa segunda tendência, que nele podem ser encontradas as direções e características predominantes da poética muriliana desde o seu princípio, realizamos a seguir a análise de alguns poemas do livro. Assim, pretendemos demonstrar também o que viemos afirmando ao longo de todo o trabalho, ou seja, que a divisão qualitativa da obra muriliana efetuada por parte da crítica não se sustenta.

\footnotetext{
${ }^{52} \mathrm{PCP}$, p. 361
} 


\section{3- A CONVERGÊNCIA POÉTICA DE MURILO MENDES}

Após o mapeamento e a análise dos pontos de vista dos críticos que compõem as duas tendências existentes na recepção da obra de Murilo Mendes realizados em nossos dois capítulos anteriores, pensamos já termos os subsídios suficientes para demonstrar, na esteira da perspectiva da segunda tendência, a não procedência da divisão qualitativa efetuada pelos críticos da primeira tendência.

É com este intuito, mas não só, que desenvolveremos neste capítulo a consideração do último livro de poemas de Murilo publicado em vida, Convergência, por acreditarmos, devido a motivos já mencionados anteriormente e nos quais pretendemos nos aprofundar, que a sua leitura aliada à discussão já realizada acerca da recepção crítica muriliana demonstrará a hipótese da impertinência da divisão qualitativa de sua poesia em fases.

Convém destacar que nosso exame de Convergência não se limitará somente a este aspecto de elucidação e esclarecimento, pois, ao analisar todo um repertório de temas, questões e procedimentos que atravessa a poesia de Murilo, será possível constatar o diálogo de sua obra com a de outros poetas e com questões caras à poesia moderna.

Acreditamos que o jogo intertextual a ser encenado no decorrer deste capítulo é rentável como estratégia de leitura da poesia muriliana e pode contribuir substancialmente para a compreensão da mesma. Aliás, pode-se dizer que este itinerário, do cotejamento, das intersecções e das convergências foi uma possibilidade aberta e oferecida a nós, leitores, pelo próprio poeta que sempre teve uma relação a mais ampla possível com a tradição literária e artística ocidental. São inúmeras as passagens de suas obras, sejam de poesia ou prosa, nas quais o poeta estabelece/indica o seu vínculo com essa longa tradição, rememorando, citando, relendo e homenageando os mais diversos escritores, poetas, músicos, pintores etc. Trataremos mais sobre esse assunto no desenvolvimento deste capítulo.

Convergência ${ }^{53}$ contém textos escritos entre os anos de 1963 e 1966, e foi publicado em 1970 pela editora Duas Cidades, de São Paulo. Trata-se de um livro escrito fora do Brasil, já que desde 1957 Murilo fixara-se na Itália visitando nosso país apenas esporadicamente. O livro é dividido em duas partes: a primeira intitulada,

\footnotetext{
${ }^{53}$ Daqui para frente para evitar repetições faremos referência ao livro por meio de sua abreviatura, CV.
} 
justamente, "Convergência" - que se subdivide em duas seções nomeadas como "Grafitos" e "Murilogramas"; e a segunda parte nomeia-se "Sintaxe". Na parte inicial, a primeira seção traz apontamentos sobre lugares e artistas, sendo que a maioria dos poemas vem designada como "grafitos em algum lugar". Ao nomear seus poemas como "grafitos", Murilo reinvindica para os mesmos a condição de "grafite", de inscrições ou desenhos feitos em espaços físicos e públicos. É assim que encontramos "grafitos" murilianos inscritos em locais diversos como muros, cadeiras, lápides, jardins, pedras etc. Outras vezes, é o próprio espaço da cidade que recebe as inscrições poéticas murilianas como nos Grafitos em Marrakech, em Meknés, em Fez, em Tânger dentre outros.

Há, também, alguns grafitos designados como "grafito para" ou "segundo" algum escritor ou artista, os quais, em geral, parecem designar, simultaneamente, tanto uma homenagem ao artista quanto uma interpretação de sua obra e, porque não dizer, um exercício de dramatização já que o eu-lírico desses poemas aparenta passar por uma espécie de metamorfose.

Esse processo é ainda mais flagrante na segunda seção dessa primeira parte, "Murilogramas": mensagens murilianas endereçadas a poetas, amigos e artistas de sua especial predileção e até mesmo a entidades como Jesus Cristo ou o Criador, por exemplo. Os murilogramas não se mostram como mera afirmação de relações de influências ou um puro transbordamento da memória afetiva na medida em que o poeta Murilo Mendes também se inscreve nos artistas que homenageia. Ao incorporar ao próprio corpo do poema citações retiradas das obras desses poetas/escritores, Murilo por sua vez, lhes concede a sua típica dicção visionária.

O recurso da citação em Murilo foi visto com minúcia por Júlio Castañon Guimarães em Territórios/Conjunções (1993). Neste trabalho, o crítico apontou não só a alta frequência de utilização deste recurso, principalmente nas produções finais do poeta, como também a sua perfeita integração no plano da dimensão crítica que ocupa boa parte da obra de Murilo. Em CV, a citação está presente em grande parte do livro, já que o poeta realiza menções a autores e artistas os mais diversos, isso quando não cita explícita e destacadamente, seja em negrito, caixa alta ou na língua original.

Com o procedimento da citação, Murilo põe em prática a ação simultânea do recorte, da colagem e da montagem, técnicas surgidas no bojo das vanguardas como o surrealismo, movimento pelo qual o poeta se enveredou. Esses recursos foram 
amplamente utilizados pelo poeta desde o início de sua produção e, se outrora ele construía com esses recursos atmosferas imagéticas imprevistas e desconcertantes, agora, em seu último livro, com o auxílio das mesmas técnicas Murilo adere a outras vozes no interior de seu texto, colocando em evidência o recurso da citação que foi considerado por Antoine Compagnon (1996) "a prática primeira do texto, o fundamento da leitura e da escrita: citar é repetir o gesto arcaico do recortar-colar, a experiência original do papel” (p. 41) ${ }^{54}$.

A segunda parte do livro, "Sintaxe", é dedicada à "fabulosa memória de Oswald de Andrade" e nela predominam poemas altamente experimentais, verdadeiros exercícios de composição poética devido aos recursos utilizados e aos efeitos atingidos. Por meio dessa dedicatória, esclarece-se, de certo modo, a origem dessa absorção do outro efetuada por Murilo, que tem sua fonte na antropofagia oswaldiana, na proposta de uma assimilação ativa e crítica da poética e experiência alheias.

Deste modo, a incorporação do outro como postura orientadora da própria experiência da criação artística de Murilo tem suas raízes no modernismo de Mário e Oswald de Andrade. Como observou José Guilherme Merquior (1994) não só Murilo, mas também Drummond, que são ambos poetas que inauguraram suas poéticas em 1930, já traziam o modernismo atrás de si, portanto, já nasceram modernistas.

Deriva desta proximidade a assimilação que Murilo fará de algumas características e procedimentos típicos do primeiro momento do modernismo brasileiro seguindo uma linha de construção de poemas que valorizará, em larga escala, o humor e a ironia. É por esse primeiro vetor, o humor, uma das maiores armas da poesia segundo Octavio Paz (1982), que começaremos, então, nossa leitura de CV.

\subsection{O Humor}

Em "Sintaxe" encontramos poemas nos quais é recorrente e marcante a presença do humor, que é suscitado e sugerido por meio de experimentações sonoras e gráficas as mais diversas. Segundo Sebastião Uchôa Leite (2003) estes procedimentos lúdicos de CV são responsáveis pela recuperação plena do humor modernista:

\footnotetext{
${ }^{54} \mathrm{O}$ crítico francês considera a leitura e a escrita como formas derivadas, substitutivas e transitórias da prática original do papel anterior à linguagem, do jogo infantil do recorte e da colagem.
} 
a segunda parte do livro (...) termina com uma recuperação plena do humor através de processos lúdicos extremados. E assim se retoma a antiga imagem do poeta-prestidigitador que tem origens longínquas, do livro, Poemas, já então totalmente 'construído', ao contrário de toda a lenda de "intuição poética” que envolveu o poeta. (LEITE, 2003, p. 62)

De fato, o humor sempre esteve presente na obra muriliana ainda que sua aparição esteja mais vinculada às suas primeiras produções e, principalmente, ao livro História do Brasil ${ }^{55}$ (1932). Nesse livro, que pode ser visto como uma espécie de paródia formal dos próprios livros de história pátria ${ }^{56}$, Murilo (re) apresenta, pelo viés satírico e irônico, momentos importantes de nossa História oficial. Dentre os vários personagens e acontecimentos históricos revisitados pelo poeta, citemos o episódio da Independência do Brasil proclamada por Dom Pedro I que aparece recriado no poema "Pescaria":

Foi nas margens do Ipiranga,

Em meio a uma pescaria.

Sentindo-se mal, D.Pedro

- Comera demais cuscuz -

Desaperta a braguilha

E grita, roxo de raiva:

"Ou me livro d'esta cólica

Ou morro logo d'ua vez!"

O príncipe se aliviou,

Sai no caminho cantando:

"Já me sinto independente.

Safa! vi perto a morte!

Vamos cair no fadinho.

Pra celebrar o sucesso."

A Tuna da Coimbra surge

Com as guitarras afiadas,

Mas as mulatas dengosas

Do Club Flor do Abacate

Entram, firmes, no maxixe,

Abafam o fado com a voz,

Levantam, sorrindo, as pernas...

E a colônia brasileira

Toma a direção da farra. ${ }^{57}$

Neste poema Murilo recria humoristicamente um episódio célebre descrito pelos compêndios de história pátria e também pela iconografia, ${ }^{58}$ por meio do deslocamento

\footnotetext{
${ }^{55}$ Doravante HB.

${ }^{56}$ Os poemas do livro tematizam, em ordem cronológica, os principais acontecimentos e personagens históricos num percurso que vai desde antes do descobrimento - pela presença de um poema-prefácio intitulado "Prefácio de Pinzón" no qual e com o qual se alude à antiga discussão que o Brasil teria sido descoberto, na verdade, pelos espanhóis de Vincente Yáñéz Pinzón - até o ano de 1930.

${ }^{57}$ PCP, p. $164-165$.
} 
da grandeza que emprestam ao evento para algo o mais prosaico possível: uma mera cólica intestinal $^{59}$. Desse modo, o poeta desfaz e rebaixa completamente a tonalidade heróica e épica desse acontecimento ao nível do escatológico. Auxilia esse tom de ridicularização a referência ao elemento local do cuscuz bem como seu consumo em excesso que teria originado a dor de barriga de D. Pedro I. Assim, a gula e a referência a um prato típico da culinária popular contrastam com a pompa e circunstância a que se associa a ideia de realeza do imperador. A linguagem utilizada por Murilo também facilitam o estabelecimento deste contraste como, por exemplo, na condensação da preposição "pra" quando o imperador após aliviar-se propõe uma comemoração: "Vamos cair no fadinho./Pra celebrar o sucesso.".

É neste sentido, de questionar toda uma construção historiográfica que cria $a$ posteriori suas versões sobre os eventos, que encontramos outro ponto de consonância entre a obra de Murilo e a de Oswald de Andrade, que, em Pau-Brasil (1925), também efetivou uma desconstrução do discurso histórico oficial pelo viés paródico-satírico ${ }^{60}$. Este interesse pela História que leva à sua re-apropriação e reelaboração literária que ocorreu sob o influxo das tendências que caracterizaram o chamado primeiro momento do modernismo marcado pelo intenso interesse e debate em torno da questão da identidade nacional.

Esse resgate e desconstrução do passado ocorrem nos dois livros por meio da utilização de procedimentos notadamente desestabilizadores e irônicos como a sátira e a paródia que se apresentam como meios eficientes de se questionar, ao mesmo tempo, o discurso historiográfico oficial, expondo suas lacunas e omissões, e a própria seriedade da arte acadêmica e bacharelesca.

Em HB Murilo parodia e satiriza a Carta de Caminha como meio de desferir sua crítica contra o colonizador. Vejamos por quais meios e procedimentos:

\footnotetext{
${ }^{58}$ Citamos neste sentido o quadro de Pedro Américo, "Independência ou Morte!" (1888) no qual a intenção de glorificação do evento é perceptível já na monumental proporção do quadro de 7,60 x 4,15 m. A obra pertence ao acervo do Museu Paulista da Universidade de São Paulo.

${ }^{59}$ Esse deslocamento efetivado para o baixo corporal do príncipe com o fim sarcástico comprova a ligação de Murilo a uma longa tradição satírica remontada por Mikhail Bakhtin em A cultura popular na Idade Média e no Renascimento: o contexto de François Rabelais (1987), trabalho no qual o crítico russo destaca a história da sátira menipéia, gênero cômico-sério que teria derivado do diálogo socrático e passado a ser o principal veículo de expressão da cultura popular medieval carnavalesca, marcada pelo realismo grotesco e pela representação do baixo corporal.

${ }^{60}$ Isso ocorre, principalmente, nas três primeiras séries do livro: "História do Brasil", "Poemas da Colonização" e "São Martinho".
} 


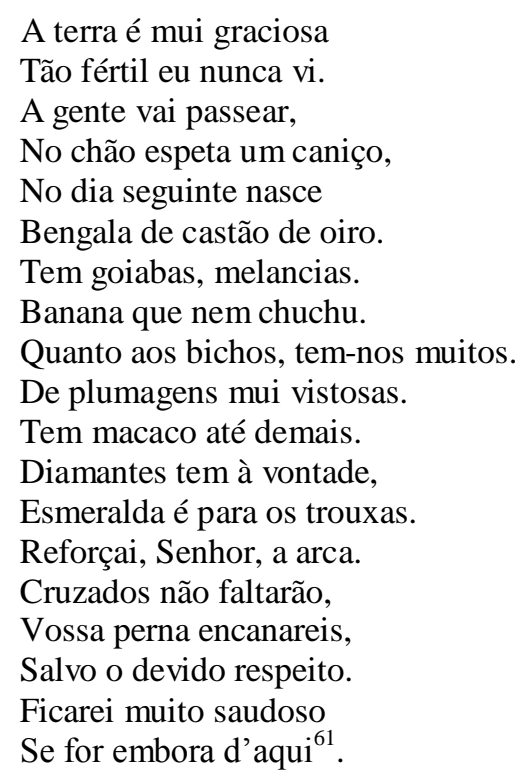

Vale a pena chamar a atenção para o recurso da citação que, como mencionamos, Murilo utilizou desde o início de sua produção, aqui, o encontramos na utilização do "mui", um termo arcaico muito utilizado na própria carta de Caminha. Este uso contrasta, no poema, com o uso formas de linguagem prosaicas como o "a gente" ou expressões populares como "banana que nem chuchu". Ao descrever as maravilhas do solo e dos bens naturais locais, o eu-lírico realiza uma espécie de caricatura exagerada do próprio entusiasmo com que o escrivão descreveu a qualidade e a fertilidade da nova terra. Todavia, é no décimo quarto verso desse poema que a crítica ao processo colonizador aparece bem marcada. Isso ocorre quando é solicitado ao Senhor, no caso, o destinatário da carta que seria o rei, que envie uma arca resistente já que os produtos da pilhagem a sobrecarregarão. Arremata o poema a confissão de que a voz que fala, no caso o português, sentirá muito pesar e nostalgia se for embora desse paraíso terreal.

$\mathrm{Na}$ criação desta atmosfera de extremo exagero do poema podemos captar, em certa medida, uma influência do surrealismo, dado que o exagero das imagens aí criadas provoca e sugere certo clima e atmosfera fantástica. Outro aspecto pelo qual podemos apreender o surrealismo nesse livro deve-se à mistura recorrente de tempos, lugares e imagens que o poeta realiza deslocando alguns acontecimentos e figuras históricas para aquela atmosfera insólita causadora daquele típico estranhamento tão caro aos textos surrealistas. É assim que vemos, em HB, por exemplo, a figura histórica de Tiradentes

\footnotetext{
${ }^{61}$ PCP, p. 145.
} 
ser condenado não ao enforcamento mais à cadeira elétrica, fato comentado por Luciana Stegagno: "o surrealismo de M. M. baralha as fichas históricas, mandando Tiradentes sentar na cadeira elétrica" (1991, p. 99). Vejamos um trecho de tão inusitado poema:

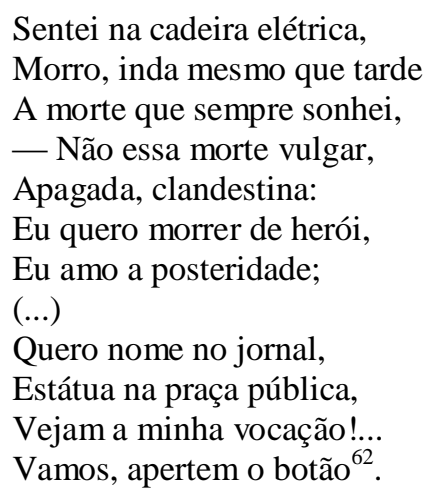

Convém falarmos um pouco mais de HB posto que seu lugar na trajetória de Murilo é bem emblemático e até polêmico, por assim dizer. Na década de 50 quando o poeta lançou uma antologia dos seus livros publicados até então, Poesias (1959), optou por não incluir $H B$, argumentando que este volume desequilibraria o conjunto e que, ademais, esse primeiro momento de sua produção já estava suficientemente representado por alguns exemplares do primeiro livro Poemas e pela inclusão integral do seu segundo livro, Bumba-meu-poeta, de 1931.

Essa opção de Murilo motivou e ainda desperta muitas inquietações em sua recepção crítica, pois há críticos que o consideram um livro importante, em consonância com a poética muriliana como um todo. Por outro lado, há aqueles que o tomam como, simples e puramente, uma manifestação episódica pouco ajustada a Murilo. Este último ponto de vista é adotado por Laís Corrêa de Araújo (1972), por exemplo, que chega mesmo a considerar HB como um livro de questionável convincência literária e reduzido alcance poético. Outros ainda destacam tratar-se de uma obra anacrônica posto que, ainda que seja claro o seu vínculo com a primeira fase do modernismo, principalmente com a obra de Oswald, como indicamos, HB foi publicado em 1932, ou seja, dez anos após a Semana de Arte Moderna.

Observando de perto a trajetória do poeta vemos que esse livro não representa um mero evento circunstancial e, muito menos, um exemplar menor em seu itinerário, pois acreditamos que Murilo realizou, nesse livro, experiências poéticas próprias.

\footnotetext{
${ }^{62}$ PCP, p. 157.
} 
Dizemos isso porque, embora seja evidente a ligação desse livro de Murilo com o de Oswald, como mencionamos, há muitas diferenças, por exemplo, entre os poemas de HB e os de Pau-Brasil. Isso ocorre não só em relação ao modo de composição, mas também, no que diz respeito aos efeitos atingidos, pois em Oswald a ironia ainda é menos corrosiva e sarcástica do que em Murilo. Quanto à diferença no que tange ao modo e aos meios de composição poética entre os dois livros, pode-se ressaltar o uso mesclado tanto do verso livre quanto do verso metrificado ou das rimas, pois em HB não é difícil verificar a presença da redondilha, tanto a maior quanto a menor, ou ainda, dos octossílabos e eneassílabos. É tamanha a liberdade a que se lança Murilo que ele não se prende a um antiformalismo rígido e à privação dos artefatos de composição poética dos quais fugiram os primeiros modernistas.

A respeito dessa provável "recusa" de HB por Murilo, Luciana Stegagno-Picchio (1991) lança a hipótese que nos parece mais adequada em relação ao fato deste livro não ter entrado na antologia "autorizada" pelo poeta em 1959, Poesias. Segundo a estudiosa, isso ocorreu exatamente porque o livro era irônico demais:

Uma ironia anos vinte, despreocupada, modernista primeira fase: a fase dos poemas-piadas, das antropofagias, do 'vamos descobrir o Brasil'. Era um humor anterior à crise dos anos trinta, ao mea-culpa regionalista e nordestino; e um humor que na altura era talvez inexportável. Com efeito, em 1952, quando parte a primeira vez para as Europas, Murilo deixa de ser um poeta modernista brasileiro, autor também de poemas-piadas, para se tornar cada vez mais poeta universal. (STEGAGNO-PICCHIO, 1991, p. 5-6)

Outro crítico, Irene Miranda Franco (2002), também indica algo parecido quando afirma que,

talvez seja justamente este aspecto - o humor uniformemente anedótico de suas paródias; espécies de caricaturas de personagens e episódios da cena brasileira - que explique o fato de Murilo Mendes recusar reunir o livro às suas Poesias de 59. Faltava-lhe uma nota de gravidade mínima. Tratava-se, talvez, de um humor cuja leveza ficava por demais impune. (FRANCO, 2002, p. 115)

Acreditamos, entretanto, que o fato de Murilo não ter incluído o livro na antologia não significa um expurgo total de parte de sua obra, pois algumas das peculiaridades deste livro, como a contestação social, o apreço pelos oprimidos e marginalizados do processo histórico, e o mais característico deles, o tom críticoirônico, persistirão ao longo de sua obra. Nesse último caso, ainda que o humor assuma 
um tom mais filosófico e contido, beirando, por vezes, o humor-negro ${ }^{63}$ - tão estimado também pelos surrealistas franceses - ele permanecerá na trajetória muriliana como uma exigência imprescindível de sua poesia. Essa necessidade imperiosa é apontada e descrita por Antonio Candido que, em resenha à antologia de Murilo publicada na França, Office Humain, observa que o humor persistirá na trajetória de Murilo ainda que de forma sublimada se comparado com seus primeiros livros:

o humor, que o poeta preferiu abafar a partir de certa altura, mas persiste todavia como elemento básico de perspectiva, e mesmo de composição, facilitando as combinações insólitas de tão grande efeito, e corrigindo certos pendores ocasionais para a grandiloqüência ${ }^{64}$.

Algo semelhante ao que indica Uchôa Leite quando afirma que ao nos embrenharmos na poesia de Murilo, percebemos que "faces esquecidas reemergem como se houvesse uma ânsia de retorno às origens" (2003, p. 62). Assim, em CV, precisamente em "Sintaxe", é possível flagrar a presença do humor, do poeta prestidigitador como quer Uchôa Leite, num poema como "Dois Tempos", por exemplo, que recorda muito os poemas do próprio HB. No entanto, agora é um acontecimento da história mundial que serve de motivo para o sarcasmo do poeta, suscitado aqui graças a um pequeno procedimento lúdico de construção, a supressão de apenas uma letra:

Ouviu-se um estampido: era Hitler cuspindo.

Ouviu-se um estampido: era Hitler cuspido. ${ }^{65}$

Citemos outro poema de "Sintaxe", "Pedra-Pomes", para ilustrar como a ironia muriliana surge devido à ludicidade decorrente do próprio procedimento de construção, por meio da presença de figuras como a aliteração e a assonância:

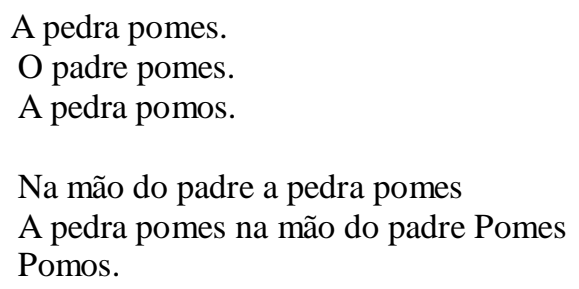

\footnotetext{
${ }^{63}$ Como observa Irene Miranda Franco em sua leitura de Poliedro: "A zombaria chega algumas vezes a tocar as raias de crueldade, e também nesse aspecto associa-se ao humor surrealista em uma de suas variantes principais: a do humor negro" (FRANCO, 2002, p. 73)

${ }^{64}$ Antonio Candido apud Murilo Marcondes de Moura. Murilo Mendes - A poesia como totalidade. São Paulo: Editora da Universidade de São Paulo: Giordano, 1995, p. 70.

${ }^{65}$ PCP, p. 713.
} 
Os pomos da pedra pomes.

O padre Pomes põe a pedra na sua mão

O padre Pomes põe a pedra no missal

Ou no míssil? $?^{66}$

Ao empregar esses recursos verbais, o poeta nos aponta um caráter de experimentação e de estudo das potencialidades sonoras das palavras, o que resulta num poema semelhante a um trava-língua, tão ao gosto da cultura popular. A propósito, julgamos necessário discorrer um pouco sobre esse aspecto de "estudos" de vários dos poemas murilianos, até porque é possível verificar ao longo de sua obra vários poemas assim nomeados.

O próprio poeta, a propósito, num auto-retrato escrito em terceira pessoa nos anos 40 atribui a muitas de suas criações essa alcunha: "Encara a poesia como fenômeno diário, constante, permanente, eterno e universal. Considera seus poemas como 'estudos' que outros poderão desenvolver." ${ }^{67}$ Destaque-se que esse termo é empregado na terminologia musical para designar peças didáticas compostas com o intuito de facilitar a aprendizagem de uma especialidade ou apurar uma determinada técnica. Ao nomear alguns de seus poemas como "estudos" ou tratá-los assim, Murilo sugere a sua esmerada dedicação e empenho com que tratava a composição poética. Como observou Murilo Marcondes de Moura (1995), usa a palavra "estudos" no que se refere à poesia muriliana no sentido de que falamos acima, ou seja, como "aproximações, exercícios ou tentativas: a sua poesia se definia tanto pela busca quanto pela obsessão do acabamento formal, e talvez mais pela primeira" (p. 59).

Esse processo de observação e experimentação das potencialidades e possibilidades da palavra poética também pode ser percebido em outro poema de "Sintaxe", "Estudos da Letra V", onde predomina o recurso da aliteração:

\author{
Lá vai a letra $\mathrm{V}$ \\ Lá vai a letra $\mathrm{V}$ voando \\ Lá vai o vector da letra $\mathrm{V}$ levando o avô \\ Lá vai o avô da letra $\mathrm{V}$ \\ La vai o avô na letra $\mathrm{V}$ \\ Voando. $\mathrm{O}$ avô da letra $\mathrm{V}$. \\ Lá vai o veleiro o vizinho o vector \\ Tudo vai tudo leva tudo vê
}

\footnotetext{
${ }^{66}$ PCP, p. 727.

${ }^{67}$ Murilo Mendes apud Murilo Marcondes de Moura, 1995, p. 59
} 
Tudo voa tudo ova ahimé! Tudo desvoa. ${ }^{68}$

Embora essa empreitada lúdica com as palavras seja mais flagrante em "Sintaxe", ela está presente ao longo de todo o livro, que é um rico reservatório de neologismos a brotarem em cada página. Essas criações imprevistas e criativas atendem a uma necessidade expressiva que visa a efeitos diversos como o humorístico, o irônico que já assinalamos, a atribuição de um ritmo e um movimento próprio ao poema, a concentração, a rapidez e a economia de expressão etc.

É assim que assistimos, em CV, a uma multiplicidade de associações e experimentações com a tessitura e o corpo das palavras. Pudemos notar a utilização frequente de processos de formação de palavras como a aglutinação e a justaposição; a desarticulação das mesmas com a consequente modificação de suas classes; a incorporação de termos de outras línguas, só para citar alguns dos procedimentos utilizados. É assim que, em “Datas”, por exemplo, os substantivos que designam alguns meses do ano adquirem estatuto de verbos:

\footnotetext{
Os magos janeiram dia 6

Os peixes abrilam dia 1

A Virgem setembra dia 8

Os mortos novembram dia $2^{69}$
}

Podemos elencar diversos exemplos de palavras que brotam de forma espontânea e vertiginosa graças ao alto poder de criatividade e liberdade com que Murilo manipula a palavra. Exemplo perfeito destas palavras-invenção encontra-se num poema de "Sintaxe" intitulado, justamente, "Palavras Inventadas (em forma de tandem)". Como "Tandem" designa um tipo de bicicleta com dois assentos: numa espécie de apropriação dessa estrutura dupla, o poema também se instala em duas colunas com palavras criadas seguindo a ordem do próprio alfabeto:

$\begin{array}{ll}\text { Ardêmpora } & \text { neclauses } \\ \text { Bisdrômena } & \text { guevolt } \\ \text { Canéstrofa } & \text { trapesso } \\ \text { Desdômetro } & \text { fanúria } \\ \text { Ervêmera } & \text { valdert } \\ \text { Ferdúmetri } & \text { bélius } \\ \text { Glamífero } & \text { glavencs }(. . .)^{70}\end{array}$

\footnotetext{
${ }^{68}$ PCP, p. 713.

${ }^{69}$ PCP, p. $726 / 727$.

${ }^{70}$ PCP, p. 730.
} 
Como exemplos de palavras formadas pelo processo de aglutinação, temos o verso "Itabiromem claroenigmático", do "Murilograma a CDA"; ou "cavalomens" e "guerromem", do "Grafito para Paolo Ucello"; ou ainda, "dioscuro", "ignirouba", "anarqlúcido" e "naviforme", presentes no "Murilograma a Rimbaud". Encontramos ainda exemplos de holofrases, processo que aglutina, numa só palavra, vários elementos de uma oração. Temos, por exemplo, no poema "Metamorfoses 6", de "Sintaxe", os termos "tremdescer" e "subirtrem". Outro procedimento muito utilizado são as palavrasvalise, que consistem em termos originados de uma ou mais palavras que se fundem formando uma nova palavra com um novo significado. Assim, temos "ocidentalexaustos" em "Murilograma a Cesário Verde"; "datilotoquei" no "Murilograma a Gabriela Mistral" e "dinamistificam" em "Grafito para Piranesi". Como amostras das palavras construídas por justaposição temos o "gentilhomem”, no "Grafito na pedra de meu pai", as "milmãos" do "Murilograma a N.S.J.C."; em outro poema, "Murilograma a Clara Rocha", temos quatro exemplos desse processo: "claroescuro", "telepessoa", "tempoespacial" e "abrefecha"71. Entretanto, não é só no processo de invenção de novas palavras que podemos verificar o uso da justaposição. Ela pode ser observada com frequência nos poemas de "Sintaxe" devido, justamente, à abolição da sintaxe. Por isso, é recorrente nessa parte do livro uma linguagem paratático-enumerativa na qual as palavras e os versos são justapostos sem ou quase sem a presença de recursos de conexão.

Nesse ponto, vale a pena lançarmos mão de dois estudos importantes a respeito destes dois procedimentos praticados por Murilo: trata-se do texto do filósofo alemão Theodor Adorno (1973), "Parataxis", e do estudo do crítico Leo Spitzer (1955), "A enumeração caótica na poesia moderna".

Em "Parataxis", Adorno realiza uma espécie de análise descritiva dos aspectos linguísticos da construção poética e dos processos paratáticos existentes na lírica tardia de Hölderlin e, ao mesmo tempo, indica certos equívocos da análise que Heidegger havia realizado do mesmo poeta. Para Adorno, a imagem originária da poesia é "síntese não-conceitual": todavia, a linguagem "devido a seu elemento significativo - contra-

\footnotetext{
${ }^{71}$ Para Joana Matos Frias (1999), a aglutinação e a justaposição podem mesmo serem consideradas como os dois mecanismos estruturantes de todo o livro.
} 
polo do elemento mímico-expressivo - acha-se vinculada à figura da sentença e da frase e com isso à função sintética do conceito" (1973, p. 99).

Desse modo, a parataxe seria um excelente meio de contestar a ordenação sintática dos versos, procedimento típico da construção hipotática, como único modo expressivo na poesia e introduzir um princípio organizacional diferente do comum que afastaria a poesia do que o filósofo chama de urteilsform ("forma do juízo"). Adorno amplia o alcance poético da parataxe e não a limita apenas a um mero modo de construção discursiva na medida em que rastreia formas diferentes de manifestação deste recurso retórico como a inversão e a enumeração. Para introduzir o caso da enumeração, o filósofo chama a atenção para Walter Benjamin, que foi, segundo o primeiro, quem tratou da questão de modo mais preciso no seu conceito descritivo de série $^{72}$. A enumeração consiste no alinhamento de palavras e/ou expressões que se equivaleriam, trata-se de um dos procedimentos paratáticos mais tradicionais já que as palavras e/ou expressões são justapostas, na maioria das vezes, sem o auxílio de recursos de conexão e coordenação.

Leo Spitzer (1955) também nos auxiliará a discutir a questão porque apresenta um panorama histórico e diversos exemplos de utilização do recurso da enumeração na poesia. Spitzer toma como ponto de partida um texto do crítico Detlev W. Schumann, que estudou o procedimento da enumeração em três poetas modernos e panteístas, segundo Spitzer, Whitman, Rilke e Werfel. Spitzer analisa e aponta no trabalho de Schumann alguns pontos frágeis ou mal desenvolvidos pelo crítico, afirmando que

ao que Schumann chamou globalmente de "estilo enumerativo" se fundem diversos elementos de época e procedência histórica distintas: a enumeração, velha como o mundo; a anáfora (em Werfel e Claudel), procedimento de fisionomia particularmente medieval; o assíndeto, conhecido na Antiguidade e ressuscitado no Renascimento, e, finalmente, o que em meu artigo sobre Salinas chamei de "enumeração caótica". (SPITZER, 1955, p. 307) ${ }^{73}$.

Spitzer (1955) analisa a enumeração caótica no conjunto de suas manifestações modernas e contra o fundo histórico do qual possivelmente teria derivado: a enumeração

\footnotetext{
${ }^{72}$ No trecho que Adorno cita de Benjamin, este ao tratar do conceito de série introduz a ideia de enumeração na poesia de Hölderlin por meio do termo 'alinhamento': "de modo que, aqui, mais ou menos na metade do poema, homens, deuses e príncipes, como caindo das suas velhas hierarquias, são alinhados uns aos outros". Walter Benjamin apud Theodor Adorno. Notas de Literatura. Rio de Janeiro: Tempo Brasileiro, 1973, p. 99.

${ }^{73}$ SPITZER, Leo. La enumeración caótica em la poesía moderna. Madrid: Editorial Gredos, 1955. A tradução é nossa.
} 
panegírica. O crítico observa que a enumeração caótica também tem sua raiz nas formas de culto religioso ${ }^{74}$ e que esta seria um dos procedimentos mais eficazes para descrever, nas litanias litúrgicas, a perfeição do mundo criado à semelhança do Criador e afirmar a onipotência divina que só poderia ser descrita por uma poderosa orquestra verbal.

O estudioso observa que, ao utilizarem a enumeração caótica, Rilke, Werfel, Claudel e Ruben Darío revivem as litanias litúrgicas cristãs e que, até mesmo no aparente caos de Whitman, está a marca dos moldes consagrados pelo cristianismo. Spitzer afirma que, ainda que a enumeração caótica de Whitman tenha sido um reflexo verbal da civilização moderna, o poeta fez com que as coisas mais díspares cantassem sua loa à alma cósmica inserindo, assim, sua poesia numa tradição milenária e cristã ${ }^{75}$.

É recorrente em "Sintaxe" a utilização de uma linguagem paratáticoenumerativa, procedimento para o qual Murilo cria regras e padrões próprios. Diversas palavras ou versos inteiros são justapostos uns aos outros: na grande maioria das vezes, são as afinidades fônicas que regem as associações as mais diversas, das quais resultará a enumeração. Para exemplificar, citemos, nesse sentido, o poema "Rotação":

\footnotetext{
A rotação da roda. A rotação do tempo.

A rotação do pé. A rotação do vento.

A rotação de Cristo. A rotação da pedra.

A rotação do som. A rotação da terra.

A rotação do não. A rotação da sombra.

A rotação do sim. A rotação do sal.

A rotação do sim. A rotação da sombra.

A rotação do não. A rotação do sol.

A rotação da água. A rotação do grão.

A rotação do ar. A rotação do fogo.

A rotação da pena. A rotação da fome ${ }^{76}$
}

A ocorrência da anáfora com a repetição do termo rotação em todos os versos atesta, conforme indicado por Spitzer, que esta figura de repetição estaria de certa forma incorporada ou sedimentada no próprio estilo enumerativo. Nota-se em diversos poemas de "Sintaxe" que o termo anafórico presente em um verso estará acompanhado de

\footnotetext{
${ }^{74}$ Spitzer cita num apêndice a esse estudo a ocorrência do estilo enumerativo também nos textos sagrados hindus como o Bhagavadgita.

${ }^{75}$ Spitzer afirma, ainda, que Whitman ampliou o esquema tradicional do culto judeu-cristão "Eu sou" (quando é Deus quem fala) e o "Tu és" (quando se fala a Deus).

${ }^{76}$ PCP, p. 715.
} 
palavras variáveis que são introduzidas por meio de jogos de palavras baseados na paronímia e homonímia numa espécie de palavra-cria-palavra ${ }^{77}$.

Outro poema no qual também é muito utilizada a enumeração é "O piano e seus parentes", no qual o substantivo anafórico piano aparece, várias vezes, justaposto com os adjetivos que o caracterizariam:

O pianoforte. O pianofraco. O pianopiano.

O piano de cauda, de cauda de mulher, de sereia, de cavalo.

Os pianos de armário. As pianolas de Arminda.

O pianopluma. O pianopeso. O pianopazzo.

$\mathrm{O}$ piano celibatário. $\mathrm{O}$ piano de pianesa. $\mathrm{O}$ pianino.

A pianesa intacta. A pianesa violada. A pianesa abolida.

Os problemas do piano. Os problemas da paz. Os problemas $\left[\right.$ do pó ${ }^{78}$

Em CV, através de uma linguagem paratática, da enumeração e por meio de arranjos morfológicos diversos dos quais derivam novas palavras, Murilo parece introduzir um princípio organizacional de liberdade em relação ao sentido comum e trivial das palavras. Desta maneira, o poeta faz com que seus versos e seus poemas fujam a uma determinação conceitual e a uma significação rígida, apontando, assim, para um sentido aberto e pluralizado.

Retomando a questão do humor, quando indicamos que esse referencial, mais precisamente, que o tom crítico-irônico não foi abandonado pelo poeta ao longo de sua trajetória e persistirá em sua poesia não queremos dizer que este tom seja o mesmo verificado em suas primeiras produções. Esse humor final verificado em CV é diverso e ainda que boa parte das vezes ele surja por meio dos jogos verbais que Murilo realiza, ele ultrapassa os meros trocadilhos e uma denotatividade com os quais alguns críticos rotulam e desqualificam o livro ${ }^{79}$.

Acreditamos com Irene Miranda Franco (2002), que essas brincadeiras verbais presentes em CV não são gratuitas e inocentes e estariam a serviço de conteúdos complexos e importantes para Murilo como esperamos ter demonstrado anteriormente quando da análise dos poemas "Pedra Pomes" e "A Rotação". Com esses arranjos, dos

\footnotetext{
${ }^{77}$ É Laís Corrêa de Araújo (2000) quem rastreia a evolução do processo de utilização deste recurso na poesia muriliana ao afirmar que o tratamento formal da sua linguagem evolui de uma composição tipo palavra-puxa-palavra (modelo barroco) ou palavra-contra-palavra (modelo surrealista) para um esquema palavra-cria-palavra (modelo concretizante).

${ }_{78}^{78}$ PCP, p. 732.

${ }^{79}$ Nos referimos aqui à perspectiva de Davi Arrigucci Jr. em "Arquitetura da memória", a qual comentaremos mais adiante.
} 
quais a autora destaca, sobretudo, o uso da paronomásia, o poeta aproxima não só palavras, mas também assuntos e temas que lhe são caros, inclusive os religiosos de modo que,

\begin{abstract}
o mundo substantivo muriliano não é um mundo de significantes manipulados aleatoriamente, mas de palavras que, integrando as imagens poéticas, vinculam lições e significados importantes e têm nexos intensos com o real. Sua concretude está ligada a uma dimensão referencial bastante significativa. (FRANCO, 2002, p. 120).
\end{abstract}

A autora ainda acrescenta, embasada na dicotomia deleuzeana, proposta em $A$ Lógica do Sentido entre um humor profundo e outro superficial, que tanto HB quanto $C V$ são livros nos quais se verifica a prevalência desse segundo tipo de humor, um humor mais brando e descompromissado. No entanto, não acreditamos que seja isso o que ocorra, pois basta ler apenas alguns poemas de HB, por exemplo, para verificar que as incursões críticas sobre o repertório da história oficial realizadas apresentam tamanha radicalidade e transgressão que fica difícil ver esse humor como meramente superficial.

Cremos que CV apresenta algo mais próximo ao que Davi Arrigucci Jr (2002) chamou de "humor caligráfico". O crítico aplica o termo para referir-se à poesia drummondiana, mas ele aplica-se também à poesia de CV. Arrigucci Jr. definiu-o como um tipo de humor que "mexe com a tessitura mesma da palavra: esta pode ser desintegrada, reintegrada, inventada ou reinventada, deformada e até revirada de pontacabeça" (2002, p. 33). É assim que esse humor "cujo aspecto lúdico reconduz por si mesmo, como se sabe, à fonte originária da criação verbal que é a poesia” (2002, p. 33), também atua como meio articulador capaz de "unir o inconsciente ao consciente, levando o sentimento à lucidez da consciência, pelo viés da ironia e as voltas da reflexão.” (2002, p. 34).

Não é de se estranhar que um poeta como Murilo, consciente das metamorfoses e transformações da vida e da poesia, dedique um de seus murilogramas de CV ao filósofo pré-socrático Heráclito, considerado como o pensador do devir, do "tudo flui" / "panta rhei”. Vejamos um trecho do poema:

\footnotetext{
Panta rhei

Todas as coisas fluem correm decorrem

Sob o sol grão

Sob o sol grande

Que nem pé de homem

Heráclito de Éfeso:
} 


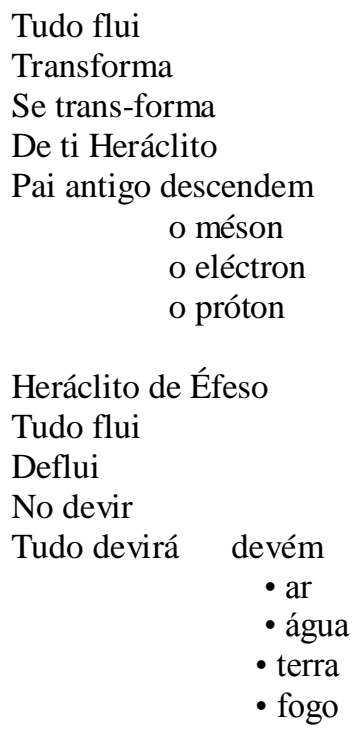

Tudo devém

visa devisa $^{80}$

Encontramos no poema a referência explícita à principal questão do pensamento heraclitiano, a ideia de que tudo está em um movimento constante, numa eterna mudança, numa contínua metamorfose. O fragmento mais célebre do filósofo, neste sentido, é aquele que se refere à impossibilidade de banhar-se duas vezes no mesmo rio: "Um não se pode entrar duas vezes no mesmo rio, nem apreender qualquer substância mortal em condição estável, mas dispersa e de novo reúne, forma e dissolve, e aproxima e afasta" ${ }^{81}$ Note-se que são tão grandes a admiração e a identificação com o pensamento do filósofo que Murilo chega mesmo a evocá-lo como pai.

No entanto, como podemos conceber a ideia da permanência de certos elementos na poesia de Murilo se, nesse momento, convocamos a referência de Heráclito cujo pensamento está fundando, justamente, na ideia da mudança contínua, do fluir permanente?

Cremos poder realizar essa observação porque encontramos na trajetória de Murilo esse movimento ambivalente e singular que inclui a transformação constante mas não o afastamento de certos referentes, que sempre retornam, ainda que modificados. De resto, as mudanças poéticas - como as de Murilo -, tão alvejadas por alguns críticos que acusam os poetas de autotraição, são um processo comum nas

\footnotetext{
${ }^{80}$ PCP, p. 701/702

${ }^{81}$ Heráclito de Éfeso, fragmento. A arte e o pensamento de Heráclito: uma edição dos fragmentos com tradução e comentário. Org. Charles H. Kahn. Trad. Élcio Gusmão Verçosa Filho. São Paulo: Paulus, 2009, p. 79.
} 
trajetórias dos poetas e não implicam, necessariamente, em negação ou abandono de suas obras e convicções anteriores.

Um caso semelhante ao de Murilo, da ocorrência de certas transformações, porém com a permanência de alguns referenciais, ocorre com a obra do também poeta mineiro Carlos Drummond de Andrade. É fato já ressaltado pela crítica que a obra drummondiana passa por algumas mudanças: desde Brejo das Almas (1934) a típica euforia modernista fora deixada de lado e, a partir do livro Claro Enigma (1951), prevalece uma estética neo-classicizante marcada por certa preocupações e inquietudes (CAMPOS 1970; CANDIDO, 1977).

Entretanto, aquele humor modernista não será de todo abandonado por Drummond em sua trajetória, como também não o foi por Murilo. Segundo Davi Arrigucci Jr. (2002), enunciando sobre Drummond afirmações que também se aplicam ao caso de Murilo Mendes, isso não ocorre porque o humor está ligado a uma imperiosa exigência do seu discurso poético:

esse gosto da brincadeira verbal, que não é meramente gratuito e se correlaciona com a necessidade expressiva do discurso poético, Drummond não o abandonará nunca ao longo de toda a sua trajetória, fazendo da linguagem aquele 'largo armazém do factível' a que se referirá, mais tarde, em Lição de coisas. (ARRIGUCCI JR., 2002, p. 33)

A respeito desse livro, outros críticos mencionam que ele apresenta uma retomada plena da vivacidade e do humor modernistas (CAMPOS 1970; CANDIDO, 1977). Outro fato similar entre os dois poetas é que, assim como Murilo em $C V$, Drummond realiza, em Lição de Coisas, uma pesquisa profunda das potencialidades das palavras e da poesia (CAMPOS, 1970; CANDIDO, 1977). Esta mesma atitude de pesquisa constante com a linguagem poética é vista por críticos como uma atitude de incorporação por ambos os poetas de certos postulados do Concretismo. Todavia, essa possível incorporação traz aspectos complexos em relação aos dois poetas, mais precisamente no que diz respeito a Drummond, que jamais manifestou adesão à poesia concreta $^{82}$. Em nota editorial presente na primeira edição de Lição de Coisas, o próprio

\footnotetext{
${ }^{82} \mathrm{Em} O$ observador no escritório, Drummond realiza uma crítica à poesia concreta e por extensão a Manuel Bandeira por aderir certos postulados do movimento e repele veementemente os mesmos: "Está na moda a poesia concreta, que devia chamar-se concretista. Manuel Bandeira, com benevolência brincalhona, dá sinais de simpatia pelo movimento dos rapazes. Nunca vi tanto esforço de teoria para justificar essa nova forma de primitivismo, transformando pobreza imaginativa em rigor de criação".ANDRADE, Carlos Drummond de. O observador no escritório: páginas de diário. Rio de Janeiro: Record, 1985, p. 113.
} 
Drummond rechaça aderir a qualquer programa poético: "Pratica, mais do que antes, a violação e a desintegração da palavra, sem, entretanto, aderir a qualquer receita poética vigente. A desordem implantada em suas composições é, em consciência, aspiração a uma ordem individual" (ANDRADE, 2002, p. 454).

Voltaremos mais adiante a relação de Murilo com o Concretismo. O que importa reter dessa aproximação, no momento, é que as obras de Murilo e de Drummond apresentam-se como obras poéticas heterogêneas e convergentes, na medida em que preservam, aliadas à sua capacidade de renovação e metamorfose, certas características e direções verificadas do início ao fim de suas trajetórias. Davi Arrigucci (2002) menciona algo muito importante no que diz respeito às mudanças ocorridas na poética de Drummond e que também vale para a poesia de Murilo: "no seu percurso histórico, o que veio depois tem tudo a ver com o que se anunciou antes e representa um desenvolvimento interno coerente da obra como um todo, exceto os percalços e descaídas ocasionais de que ninguém está salvo" (p.21). Assim, a fidelidade a si mesmo que Arrigucci Jr. registra no caso de Drummond, é um traço fundamental da obra tanto do poeta de Itabira quanto de Murilo Mendes. Para Murilo, como para Drummond, valem as palavras de Octavio Paz (1972) ao comentar a obra do poeta Juan Ramón Jimenez: "em todas as suas mudanças [...] foi fiel a si mesmo. (...). Sua coerência é como a da árvore que muda mas não se desloca.” (p. 33)

\subsection{A metalinguagem/autorreflexividade}

Embora a preocupação com a crítica da linguagem poética venha de longe na história literária, pois já alguns poetas clássicos tinham concedido atenção especial a este elemento, a autorereflexividade se tornou um traço marcante da poesia moderna. É flagrante e frequente o quanto os poetas modernos abriram espaço no interior de suas obras para uma abordagem crítica da linguagem poética. Essa peculiaridade marca a poesia de vários escritores e poetas modernos como Poe, Eliot, Baudelaire, Rimbaud e Mallarmé, por exemplo.

Segundo João Luiz Lafetá (2000) a literatura dita "moderna" assumiu o que em nenhuma outra época foi realizado: a posição crítica como um elemento constituinte interno. Outro crítico, Davi Arrigucci Jr. (2002), também confirma isso ao indicar que a 
incorporação de sua própria crítica no interior do projeto de construção da obra é uma das marcas da tradição moderna. É como se se instaurasse uma exigência à poesia moderna de ser reflexiva não só em relação às obras que a precederam, mas também em relação à sua própria estrutura, ao seu próprio fundamento enquanto prática escrita plurissignificante.

Dessa forma, através da incorporação total daquilo que os formalistas russos designaram como "desnudamento do procedimento" ${ }^{83}$, os poetas modernos colocaram em evidência os bastidores de seus poemas. Assim os poetas modernos romperam definitivamente com a estética ilusionista que pressupunha que o poema expressaria algo externo a ele, seja um sentimento ou pensamento do poeta.

Em Murilo podemos colher, desde o início de sua produção, vários exemplos desse posicionamento reflexivo. Neste sentido, pode-se apontar a metalinguagem como mais um dos vetores de sua poesia, Assim, temos em A Poesia em Pânico (1937), por exemplo, um poema intitulado "Poema visto por fora", onde se diz:

O espírito da poesia me arrebata

Para a região se forma onde passo longo tempo imóvel

Num silêncio de antes da criação das coisas. (...) ${ }^{84}$

É possível verificar, também, em vários poemas de Murilo Mendes uma espécie de ligação ou simbiose entre o discurso metapoético e o religioso, no sentido de atribuição de um aspecto sagrado e libertário à poesia, como nesses versos do poema de Poesia Liberdade, "Contemplação":

A poesia está preparada
Para a pesca milagrosa e natural. (...)

Em CV, essa dimensão metalinguística é notória, pois nesse livro, como indicamos, Murilo discorre permanentemente sobre a tradição cultural e literária, convocando-a para falar com ele e compor os seus poemas, grafitos e murilogramas. $\mathrm{Na}$ maioria dos poemas do livro, Murilo está em diálogo com a obra de outro, o que por si só já aponta para a preocupação metalinguística que caracteriza a obra. Ao tentar interpretar a dicção alheia, Murilo se serve dela como uma forma de expressão e de

\footnotetext{
${ }^{83}$ Salvo engano, tal expressão foi cunhada pelo formalista russo Victor Chklovsk em "Teoria da prosa" ao tratar do romance Tristram Shandy de Laurence Sterne.

${ }^{84}$ PCP, p. 285

${ }^{85}$ PCP, p. 430
} 
diálogo, adotando, como já dissemos, algo do estilo do outro, mas, como também dissemos anteriormente, inclui e confere o seu tom às obras desses artistas numa espécie de "polifonia" poética, ponto do qual trataremos mais adiante. Além do mais, não é de se estranhar que Murilo incorpore a crítica à sua poesia. Recordemos que ele foi crítico de arte por um bom tempo e também escreveu artigos sobre música, que posteriormente foram reunidos num volume intitulado Formação de discoteca (1993).

José Guilherme Merquior (1994) indica em "Notas para uma Muriloscopia" que essa privança de Murilo com a literatura parece ter sido um fermento constante de sua poesia, pois foi convertida em matéria poética ao longo de toda a sua obra ainda que seja vista, por alguns críticos, como exagerada contaminação de sua poesia pelo tema literário. Entretanto, não cremos que sua poesia perca sua vitalidade devido a isso, pelo contrário, é justamente, nessa especificidade, nesse contato visto como nocivo por alguns, que acreditamos residir parte da força e do tom poéticos murilianos.

Encontramos em $\mathrm{CV}$ dois poemas metalinguísticos bem singulares cujos títulos são bem semelhantes. Ambos encontram-se em "Sintaxe": o primeiro, que abre essa parte, denomina-se "Texto de Informação"; e o segundo, que fecha tanto "Sintaxe" quanto o próprio livro, intitula-se, "Texto de Consulta". O primeiro poema traz uma espécie de suma poética do próprio livro na medida em que o poeta, por meio da autorreflexividade indica o seu proceder frente à atividade poética num desnudamento completo do ato criador. Vejamos algumas estrofes de "Texto de Informação":

2

Tiro do bolso examino

Certas figuras de gramática de retórica de poética

Considero-as na sua forma visual

Fora de função/no seu peso específico

\& som próprio de palavras isoladas:

Oxímoron; anáclase. sinérese

Sinédoque. anacoluto. metáfora

Hipérbato. hipérbole. hipálage Assíndeto

3

Ponga, s.f. (Bras. Norte) Espécie de jogo. Consiste num quadrilátero de madeira ou papel em que se traçam duas diagonais e duas perpendiculares que se cruzam e em que se jogam dados. 


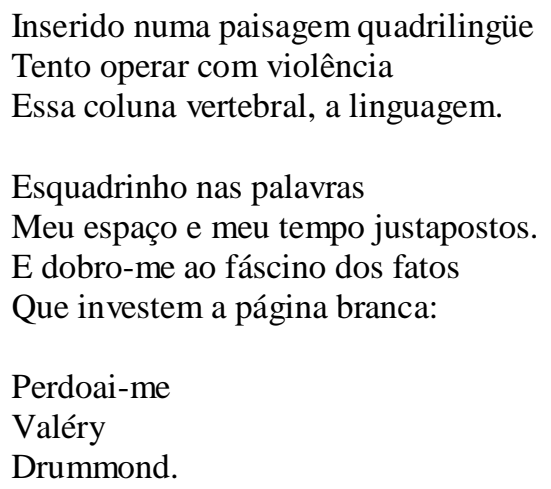

....as palavras/coisas/são belas

No seu vestido justo

Criado por alfaiates-óticos. ${ }^{86}$

Vemos que o poeta assinala uma forma bem específica para indicar seu trato com os materiais da poesia ao utilizar os verbos "examinar" e "operar", que trazem a ideia de submeter algo/alguém/alguma coisa a uma investigação minuciosa.

Como se vê no poema, casam-se forma e sentido quando o sujeito lírico diz que considera as palavras no "seu peso específico" de "palavras isoladas" e passa a enumerar, a seguir, várias figuras de linguagem, separando-as por ponto final. Indica a mesma coisa a última palavra da lista, "assíndeto", nome do recurso estilístico utilizado nos versos anteriores do poema, onde se procede a uma enumeração sem a utilização de conjunções aditivas.

Outro aspecto que nos interessa chamar a atenção no poema é que essa investigação minuciosa que o poeta relata empreender e, de fato, realiza enquanto a descreve, não poupa nem mesmo a inserção de um verbete de dicionário, que aparece isolado como uma estrofe independente do próprio poema. No verbete temos uma palavra sintomática, "ponga", descrita como uma espécie de jogo com dados. É difícil não ver aí, além do processo metalinguístico explícito, a ideia de jogo aleatório associado à poesia, essa que é "a grande inimiga do acaso, embora sendo ela também filha do acaso e sabendo que este em última instância ganhará a partida" (CALVINO, 1990, p. 84) ${ }^{87}$.

\footnotetext{
${ }^{86}$ PCP, p. 706.

${ }^{87}$ Seis propostas para o próximo milênio: lições americanas. São Paulo: Companhia das Letras, 1990.
} 
Entretanto, se as imagens do "exame" e da "operação" indicam certo controle e rigor no trato com a linguagem poética, ao introduzir no poema um neologismo ambíguo, "fáscino", o poeta indica o lugar que os fatos desempenham em sua poesia. Por um lado, eles o fascinariam e, por outro, conduziriam autoritariamente o material e a feitura dos poemas. Considerando esta possibilidade, fica claro o motivo de o poeta em seguida pedir perdão a dois poetas notórios, Valéry e Drummond, que atestaram, em suas composições, uma nítida aversão aos fatos como material imprescindível da poesia.

Drummond, ao lançar em 1951 o livro a que já nos referimos, Claro Enigma, escolhe para epígrafe do volume, justamente, um verso de Valéry: "Les événements m'ennuient", que numa livre tradução seria algo como "Os acontecimentos me aborrecem". No entanto, não é só nesse livro em especial que Drummond indica essa postura de aversão aos fatos como temas poéticos, pois em A Rosa do Povo (1945), um de seus livros mais marcantes, o poeta desenvolve essa reflexão num dos seus mais clássicos metapoemas, "Procura da poesia".

No outro poema de CV que já mencionamos, "Texto de Consulta", o eu-lírico parece, justamente, proceder a indagação do que é poesia ao se questionar e levantar hipóteses sobre o que é o poema, sua constituição, sua origem e sua relação com outros textos. É interessante o fato de tanto este quanto o poema que acabamos de discutir terem sido intitulados, justamente, como "textos". Como no termo "estudos", de que já falamos aqui, em "textos" ressalta-se o caráter de construção e de exercício linguístico de seus poemas. No entanto, esses dois poemas/textos não perdem aquela capacidade latente da poesia de materializar a subjetividade de um sujeito que diz algo acerca de alguma coisa. No caso de "Texto de Consulta", a indagação sobre o poema desemboca numa reflexão sobre o poeta, que termina por admitir, afinal, ser ele mesmo um mero objeto do poema:

O poema é o texto? O poeta?

O poema é o texto + o poeta?

O poema é o poeta $-\mathrm{o}$ texto?

2

O texto deriva do operador do texto

Ou da coletividade - texto?

O texto é manipulado

Pelo operador (ótico)

Pelo operador (cirurgião)

Ou pelo ótico-cirurgião? 
Existe um texto regional/nacional

Ou todo texto é universal?

Que relação do texto

Com os dedos? Com os textos alheios?

\section{9}

O texto-coisa me espia

Com os olhos de outrem. ${ }^{88}$

Esses últimos versos reiteram algo que já apontamos anteriormente, isto é, a tendência da poesia muriliana de se construir "em diálogo" com outras obras. Esse recurso é recorrente ao longo de toda a trajetória do poeta, mas precisamente em $\mathrm{CV}$ apresenta-se como um verdadeiro modus operandi. Em seu último livro, ao mesmo tempo em que homenageia e analisa o estilo de outros artistas, Murilo, sem perder a sua dicção peculiar, demarca todo um campo de ressonâncias e influências da sua poesia. Inclusive, chega a realizar esse exame da alteridade também com a obra de Drummond em "Murilograma a C.D.A.":

No meio do caminho da poesia selva selvaggia

Território adrede

Desarrumado

Onde palavras-feras nos agridem

Encontrei Carlos Drummond de Andrade (...)

Na oficina-laboratório

Itabiromem claroenigmático

Extrai do léxico

Uma lição de coisas.

Enxuto sobre o manúbrio

À brisa sarcástica de Minas.

Dorme acordado.

Glossógrafo declancha

Com seus olhos de termômetro

A máquina do mundo da linguagem

Em contacto contraste atrito \& rotação

Diurna. (...)

Deflagrando história \& semântica

Radiografa o

Desgaste do mundo coisificado. (...)

\footnotetext{
${ }^{88}$ PCP, p. $737-740$.
} 
Além de Cummings \& Pound
Além de Sousândrade
Além de "Noigrandes"
Além de "Terceira feira"
Além de Poesia-Práxis
Além do texto "Isso é aquilo"
Sereis teleguiados?

Resta a ságoma de Orfeu

Com discurso ou sem.(...) ${ }^{89}$

É assim que Murilo faz de seu murilograma um exercício de leitura da poética drummondiana, captando toda uma gama de referenciais da própria trajetória poéticopessoal do poeta de Itabira. Nesse metapoema, ao captar e recriar a essência da arte do outro, Murilo se contamina dela sem, contudo, perder a sua afiada sensibilidade poética e o poder de transformação/metamorfose de sua poesia.

\subsection{A voz múltipla de Murilo Mendes}

Esse processo de interpenetração das vozes é de tamanho alcance, em CV, que em "Grafito segundo Kafka" o eu-lírico, numa espécie de dramatização poética, assume a voz do escritor tcheco. Ao empreender uma conversa com a obra do autor de Metamorfose, o sujeito poético apropria-se da e se transforma na voz do outro, transformação que pode ser acompanhada logo no início quando, após a primeira estrofe, o eu-lírico toma a voz de Kafka o que vem indicado pela letra K seguida de dois pontos:

1

Marcar a solidão, sem consciência,

Sem lâmpada, sem mapa ou mão tangente,

Trocando as letras do seu próprio nome. Que tinhas de comum contigo mesmo?

Bastava-te o respiro da palavra.

Tua testa, teus pulmões tramaram contra

Ti. Autoabandonado antes de alguém te.

${ }^{89}$ PCP, p. 689-690. 
$\mathrm{K}$ :

Todos falam da morte paralém:

Eu falarei da morte paraquém:

A partir dessa segunda estrofe, o eu-lírico incorpora completamente a voz do escritor tcheco com toda a sua carga de niilismo e seu tom pessimista, expressos em várias imagens cujos conteúdos remetem a temas kafkianos visíveis: a imagem da perda ("Perdia a carta o passaporte o eco"); o fechamento extremo e a incomunicabilidade ("Magazines fechados./Tudo está, sempre/ Esteve fechado./Alfabeto partido./A fechadura fecha, não se abre.”).

Conjugadas a essas imagens surgem também outras que nos remetem ao absurdo e ao insólito do surrealismo demonstrando que, este referencial, também estará presente em CV:
A escada rolante, em sentido contrário:
Sobe para baixo, desce para cima.
O anúncio luminoso ilumina o sabão.
O ônibus conduz-me ao armazém de Anubis.
Para quem apelar? Telefonam em chinês.
Telegrafar à ONU? A resposta em kafkês. ${ }^{90}$

Há aí, também, a imagem insólita do ônibus que conduz à morte, conforme a referência ao "armazém de Anubis", nome do deus egípcio com cabeça de chacal que era considerado o guardião dos túmulos e da vida após a morte. Diante do fim próximo e angustiante, resta mais uma vez o vazio, a impossibilidade de comunicação e de socorro. Há aqui, também, uma alegorização aos campos de concentração nazistas que vem indicada num verso no qual o poeta aglutina os termos que formam a palavra: “campoconcentração: só para o imbele" ${ }^{91}$. É fato já ressaltado por alguns críticos que a obra de Kafka, que retratou tão bem o absurdo das relações humanas submetidas ao autoritarismo, não deixa de ser uma (pré) visão profeticamente antecipadora dos horrores que surgiriam sob a experiência do nazismo. É realmente chocante e incrível a similaridade entre o flagelo dos judeus perseguidos e massacrados sem alegação alguma de culpa pelo regime nazista e a perseguição que se abate sobre Josef K., que "uma manhã foi detido sem ter feito mal algum" (KAFKA, 2005, p. 7) é condenado à morte sem ao menos ser julgado. A identificação de Murilo com a visão do mundo como

\footnotetext{
${ }^{90}$ PCP, p. 647-648.

${ }^{91}$ PCP, p. 649.
} 
absurdo expressa-se também em "Grafito segundo Kafka" quando o eu-lírico afirma ser "O absurdo, nosso pão cotidiano,/Nossa técnica atual de asfixia".

Esta visão do mundo, como vimos acima, tem muito a ver com os horrores da guerra. Em muitos poemas de $\mathrm{CV}$ podemos colher referências à guerra ainda que estas sejam menos frequentes e imageticamente menos intensas do que aquelas que o poeta utilizou na "poesia social" de Poesia Liberdade, livro que, como já mencionado, é visto pela crítica como seu livro mais comprometido com a realidade contingente da Segunda Guerra $^{92}$. Pertencem a este livro dois dos poemas mais célebres de Murilo, "Janela do caos" e "Aproximação do terror", nos quais, por meio do tom apocalíptico de matiz religiosa e de imagens alegóricas incômodas e paradoxais, o poeta relacionou religião, história e poesia (MOURA, 2001, p. 109).

Ainda no que concerne ao processo de assimilação de vozes que Murilo realiza em sua poesia, no poema/texto já citado por nós, "Texto de consulta", o poeta se serve do nome próprio de alguns de alguns escritores, poetas e artistas que lhe serviram de referência conjugando-os como verbos:

Eu tenho a vista e a visão:

Soldei concreto e abstrato.

Webernizei-me. Joãocabralizei-me.

Francispongei-me. Mondrianizei-me $\mathrm{e}^{93}$

É assim que Murilo demonstra aguda consciência de sua multiplicidade poética, desse "desdobrar de planos" de sua poesia que, embora se aproprie do outro, consegue manter sempre aquela tonalidade visionária e crítica próprias à sua poesia. Assim, se o poeta afirma ter se "joãocabralizado" e se "mondrianizado", segundo Sebastião Uchôa Leite (2003) "ficou um Cabral desafinado e um Mondrian de linhas tortas" (p. 71).

A propósito desta multiplicidade de Murilo, já nos havia chamado a atenção o próprio Uchôa Leite ao indicar estar subjacente à obra muriliana uma meta múltipla, uma trilha múltipla com várias direções ${ }^{94}$. Esta multiplicidade pode ser verificada em diferentes planos e sob diversos pontos de vista, como, por exemplo, essa espécie de "polifonia" poética que se instaura na poesia muriliana. Em "Bakhtin, Murilo, prosa/

\footnotetext{
92،“(...) Poesia Liberdade é o livro de Murilo Mendes em que é mais flagrante a decisão de fazer "poesia social'(...)." (MOURA, 1994, p.154).

${ }^{93}$ PCP, p. 737-740.

94 Sebastião Uchôa Leite indica três delas que seriam as principais e que já mencionamos em nosso capítulo anterior: o poeta crítico-irônico, o poeta voltado para a cotidianidade e o poeta reflexivo.
} 
poesia”, Boris Schnaiderman (1998) comenta a respeito da multiplicidade e do confronto de vozes existentes na poesia de Murilo Mendes bem como de seu dialogismo.

Este, como viemos ressaltando, manifesta-se no diálogo permanente de Murilo com a tradição cultural, contato que se transforma no que Boris chama de "diálogoadesão" / "diálogo-convívio" na medida em que a voz do poeta adere a outra voz, "colase ao objeto, aprende-o antropofagicamente desdobra-se de acordo com as novas coordenadas traçadas pelo texto que apreende, mas sem deixar jamais de ser Murilo" (SCHNAIDERMAN, 1998, p. 78) $)^{95}$.

Boris apresentou, em seu texto, as dúvidas, hesitações e os sofrimentos morais possíveis de serem flagrados na voz múltipla de um sujeito lírico que se desenha na obra de Murilo e que antecedeu a sua conversão realizada em 1934 por ocasião do falecimento de Ismael Nery. Segundo Schnaiderman, haveria em alguns desses poemas o enfrentamento entre "a voz do cristão contrito" e "aquele moleque desabusado voltado para os prazeres terrenos" (1998, p. 77).

Contudo, podemos dizer que esse conflito muriliano continuará presente em abundância mesmo nos poemas pós-conversão, o que permitiu a Murilo a adoção daquele tom herético que foi notado e criticado por Mário de Andrade em seu artigo "A poesia em pânico". Exemplos que confirmem esse conflito não faltam: muitas vezes ele vem expresso na forma de um duelo entre "o mundo das formas", revelado na visão do corpo e da sensualidade da mulher, e os deveres da espiritualidade. Já oferecemos um exemplo disso quando citamos o poema "Igreja Mulher" no qual o eu - lírico manifesta esse conflito entre o mundo de Deus e o mundo das formas, sobretudo, as formas femininas. Encontramos outro exemplo disso no "Poema Condenado", de A Poesia em pânico:

Eu te respiro por todos os poros:

Mulher, estás em todos os lugares.

Prefiro me danar a um dia te perder de vista.

Teu vestido desdobrado esconde a Cruz.

Se este sortilégio acabasse eu me mataria. ${ }^{96}$

\footnotetext{
${ }^{95}$ É interessante o fato de que Boris parte para a consideração das vozes poéticas em Murilo a partir da ideia de dialogismo de Bakhtin que o próprio crítico russo afirmou não ser aplicável nem ao teatro nem à poesia. No entanto, para Boris as categorias estudadas por Bakhtin em relação à prosa de ficção funcionam admiravelmente no exame dos textos poéticos já que "o que ele [Bakhtin] nos desvenda, como visão de mundo e como visão de texto, vai muito além da distinção que se costuma estabelecer entre prosa e poesia" (SCHNAIDERMAN, 1998, p. 79).
}

${ }^{96}$ PCP, p. 309. 
Por sua vez, esse dialogismo de Murilo, esse "diálogo-adesão" que ele implanta com a tradição literária deve-se ao fato de que ele "vive a história literária como lugar da pura coexistência" (FRIAS, 2002, p. 26). Com isso, nosso poeta se aproxima do modernismo anglo-americano nas suas figuras principais, Ezra Pound e T. S. Eliot, pois essa questão, da polifonia entendida como confluência ou convergência de toda a tradição literária no espaço poemático, também atravessa a poesia de ambos (FRIAS, 2002). Esse "diálogo-convívio" faz com que surja na poesia muriliana essa voz múltipla, bem como, certos temas e questões que também não deixam de estar relacionadas àquela sua predisposição peculiar: o seu anseio e busca pela totalidade da vida. Além do mais, esse processo de multiplicação da voz poética demarca mais um dos pontos da obra muriliana que se relacionam às questões importantes que atravessaram o desenvolvimento da poesia moderna, neste caso, a ideia da despersonalização e do cultivo das máscaras poéticas.

Muitos críticos analisaram o ato da despersonalização poética na poesia moderna, sendo um dos trabalhos mais célebres o do crítico alemão Hugo Friedrich, Estrutura da Lírica Moderna (1956). Nesse trabalho o crítico conceituou a despersonalização como uma espécie de ruptura entre a pessoa empírica do poeta e o sujeito lírico do poema. Esse livro de Friedrich teve ampla divulgação e notável aceitação no círculo dos pesquisadores e estudantes da poesia moderna: todavia, com o passar dos tempos, sua perspectiva passou a ser questionada por outros autores. Dois deles, Alfonso Berardinelli (2007) e Michael Hamburguer (2007), indicaram a parcialidade de seu ponto de vista, o que lhe teria permitido fazer considerações equivocadas além de fechar sua explicação sobre a poesia moderna exclusivamente na poesia francesa representada nas obras de Baudelaire, Rimbaud e, principalmente, Mallarmé. Por isso, segundo Berardinelli "a maior parte da poesia do século XX entra com dificuldade no esquema de Friedrich" (BERARDINELLI, 2007, p.19). Berardinelli ainda aponta que um desses enganos está presente desde o próprio título do livro, pois segundo o crítico italiano: "não há uma estrutura generalizável na poesia" (2007, p. 08). O crítico ainda observa diversas "zonas de esquecimento" do livro de Friedrich, que teria desvalorizado ou omitido algumas questões e figuras centrais para a poesia moderna. Dentre as questões relegadas por Friedrich, duas delas receberam um tratamento mais minucioso por parte de Berardinelli. A primeira é a fusão e o rearranjo 
dos gêneros, a aproximação verificada entre a poesia e prosa ${ }^{97}$; a segunda questão é a da diversidade de vozes poéticas que tem como um de seus textos inaugurais o ensaio do poeta e crítico T. S. Eliot, As três vozes da poesia no qual o crítico italiano parece apoiar o seu conceito de voz poética. Das três vozes propostas por Eliot neste ensaio, Friedrich, segundo Berardinelli, teria priorizado e analisado somente uma, a terceira, representada na voz do poeta que se despersonaliza: "quando ele [o poeta] procurar criar uma personagem dramática falando em verso" (ELIOT, 1997, p. 97) ${ }^{98}$.

No entanto, esse esfacelamento da personalidade individual e empírica do poeta em prol da criação de personalidades múltiplas ${ }^{99}$ foi algo implementado por vários poetas ao ponto de ser erigido como uma necessidade poética quase irrefutável: “dificilmente há um poeta moderno digno de ser lido que não solicite ao leitor que entenda e leve em consideração 'a verdade das máscaras"” (HAMBURGUER, 2007, p. 115). Além disso, a personalidade múltipla se mostrou um grande dilema na vida e obra de alguns poetas, dentre os principais deles, Eliot e Pound que, segundo Michael Hamburguer (2007), usaram e abusaram da criação de personae líricas com uma liberdade sem precedentes na poesia ainda que por razões pessoais e poéticas diversas. Essa razão pessoal aludida é muito evidente na obra de Eliot se pensarmos, por exemplo, na própria necessidade de teorização a respeito do tema que o poeta desenvolveu em seu famoso ensaio "Tradição e talento individual". Nele, Eliot expõe a ideia de que a evolução artística de um poeta tem de ser um prolongado auto-sacrifício e uma contínua extinção de personalidade. Entretanto, o preceito da impessoalidade formulada por Eliot era, segundo Hamburguer (2007), não uma doutrina literária ou

\footnotetext{
${ }^{97}$ Preocupação que, ademais, indica o próprio título do livro de Berardinelli no qual consta esse e outros textos, Da poesia à prosa. Essa questão será analisada pelo crítico, principalmente, no capítulo "Baudelaire em prosa" no qual ele desenvolve, numa combinação de leitura dos textos e dos dados biográficos do poeta, a consideração da necessidade de Baudelaire, em sua poesia, de se utilizar da prosa e de seus instrumentos para se comunicar. Para Berardinelli é nesse amalgamento que pode ser verificada a modernidade de um livro como os Pequenos Poemas em Prosa (1864) que ainda que tenha sido um livro desafortunado e um projeto incompleto durante a vida do poeta, pode ser visto, atualmente, como uma obra-prima, um verdadeiro documento da modernidade poética no qual Baudelaire expressou "o seu amor e horror pelo presente, sua idéia da literatura e da poesia como evasão impossível e denúncia impotente" (BERARDINELLI, 2007, p. 57)

${ }^{98}$ Convém citar o trecho no qual Eliot menciona quais seriam as outras duas vozes: "A primeira voz é a do poeta falando para si mesmo - ou não falando para ninguém. A segunda é a voz do poeta dirigindo-se a um auditório, grande ou pequeno." (ELIOT, 1997, p. 97)

${ }_{99}$ Lembremos um dos maiores, senão o maior caso de pluralidade na poesia moderna que é a poética de Fernando Pessoa que se desdobrou em vários heterônimos cada um com uma poesia bem peculiar. Não é ainda muito claro o número final dos heterônimos pessoanos, provavelmente aproxima-se de uma centena e meia ultrapassando os 72 fixados por Teresa Rita Lopes (1990) em Pessoa por Conhecer, as dramatis personae. A última contagem foi realizada por José Paulo Cavalcanti Filho (2011) em Fernando Pessoa: uma quase autobiografia e chegou à amostragem de 127 heterônimos.
} 
estética, mas sim uma necessidade pessoal: "uma derivação objetiva das necessidades arraigadas nas peculiaridades de sua própria natureza e situação, as de um poeta atormentado além do suportável pelo caráter fortuito e fragmentário da civilização moderna" (2007, p.180).

Muitos poetas utilizaram as máscaras poéticas numa tentativa de fuga ao uso da primeira voz na poesia pelo risco que corriam de ela ser interpretada como sua própria voz pessoal, todavia, o uso da primeira pessoa num poema lírico jamais deveria ser identificado (ainda que isso possa ocorrer), em qualquer caso, ao eu empírico do poeta: "quer fundamentalmente confessional quer fundamentalmente dramática, a primeira pessoa na poesia lírica serve para transmitir um gesto, não para documentar a identidade nem estabelecer fatos biográficos" (HAMBURGUER, 2007, p.115). No entanto, esse fato, de o "eu" da poesia lírica ser uma criação ou uma função do poema não pareceu evidente o bastante a alguns poetas já que os exemplos da meditação e indagação sobre o eu literal/empírico podem ser encontrados em abundância na poesia moderna (HAMBURGUER, 2007, p.160).

$\mathrm{Na}$ obra de Murilo também encontramos essas indagações a respeito do "eu", como neste poema cujo título é bem sintomático, "Conhecimento", de A Poesia em Pânico:

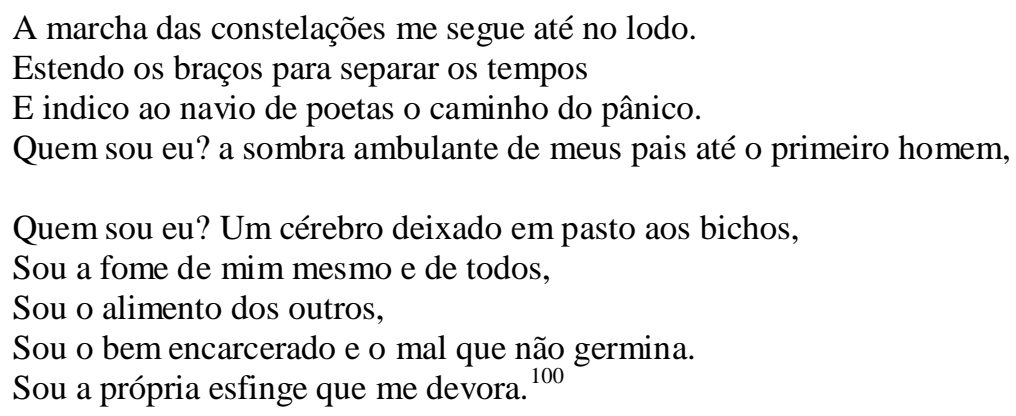

No poema, o próprio "eu" indaga-se sobre a sua identidade elaborando, também, as possíveis respostas para essa questão existencial. Essa busca pela empreendida pelo sujeito lírico pela própria identidade ocorre também em CV. Em “Grafito no Pão de Açúcar”, por exemplo, vemos que o poema se constrói a partir de dados autobiográficos que são recriados estética e imageticamente por Murilo que relaciona algumas de suas descobertas afetivas e estéticas ocorridas na cidade do Rio de Janeiro:

${ }^{100}$ PCP, p. 301. 
No cume desta colina

Nove bilhões de anos

Contemplam-nos.

Neste Rio descobri

O Brasil/ cruz e delícia

Saudade da minha amada.

Neste Rio ásperofísico

Nomeei-me poeta.
Aqui conversei
Ismael Nery
Mestre/ malungo máxime
Entre canto gregoriano e jazz.
Aqui aprendi
Presto a ser
Espiritualmente semita
Alimentei-me de Índia.
Daqui vi crescer
A novíssima Israel:
Karl Marx/Freud/Einstein.
Daqui pude aferrar
Picasso/Mallarmé/Strawinski
Lutei com o verbo encarnado.
Matéria fui/para forma.
Aqui toquei imediato
Ou por tangência \& contaminação
Múltiplas coisas grandes
Visíveis invisíveis. ${ }^{101}$

Em outros momentos de sua obra, o "eu" do poema assinala o seu lugar, o de poeta, como o responsável e/ou propiciador de uma efetiva mudança/transformação do mundo pela arte que, como vimos, foi um dos anseios dos surrealistas. Assim, a poesia é vista como uma atividade humana capaz de estabelecer condições reais para um mundo mais digno, idéia que pode ser verificada, principalmente, em alguns poemas escritos no contexto da segunda guerra, como "Ofício Humano", por exemplo:

As harpas da manhã vibram suaves e róseas.

O poeta abre o seu arquivo - o mundo -

E vai retirando dele alegria e sofrimento

Para que todas as coisas passando pelo seu coração

Sejam reajustadas na unidade. ${ }^{102}$

\footnotetext{
${ }^{101}$ PCP, p. 633-634

102 PCP, p. 408.
} 
Como pudemos notar, há na poesia de Murilo uma grande diversidade de inquietações, temas e propósitos: logo, não nos espanta que o poeta tenha lançado mão de uma voz múltipla para dar conta dessa variedade de interesses, dessas "múltiplas coisas grandes" às quais o eu-lírico indica "tocar" no "Grafito no Pão de Açúcar", como vimos. Seu verso polifônico representa um meio encontrado por ele para dar conta de representar o caos e a multiplicidade inerentes à própria vida moderna. Esse entrecruzamento de vozes põe em evidência a pluralidade do homem e da linguagem e o fato de que os dois são, por natureza, diálogo, como nos recorda muito bem Octavio Paz:

O homem é pluralidade e diálogo, concordando e juntando-se consigo mesmo, mas também dividindo-se sem cessar. Nossa voz são muitas vozes. Nossas vozes são uma só voz. O poeta é ao mesmo tempo o objeto e o sujeito da criação poética: é o ouvido que escuta e é a mão que escreve o que é ditado por sua própria voz. (PAZ, 1982, p.201-202).

Esse dialogismo muriliano, a construção desta sua voz múltipla ancorada em outras vozes, sobretudo, no diálogo com a tradição literária, só ressalta uma multiplicidade que já era inerente à sua própria poesia. Isso se dá devido à abertura de criação que Murilo sempre manifestou que se revela numa ampla série de interesses, temas e procedimentos com os quais ele construiu sua poesia. Esses referentes que, embora, algumas vezes, aparentam terem sumido, sempre retornam em sua obra garantindo-lhe esta voz típica de sua poesia: a de um poeta que adere ao ser, um "poeta cósmico e social que aceita a fruição dos valores primordiais" (BOSI, 2006, p.447). Assim, essa "arquitetura polifônica de um céu/Que se nutre da matéria humana", ${ }^{103}$ esta voz múltipla que ecoa em sua obra lhe possibilitou a manifestação daquela "voz outra", a voz da poesia que, como recorda muito bem Octavio Paz, é outra porque,

\footnotetext{
é a voz das paixões e das visões; é de outro mundo e é deste mundo, é antiga e é de hoje mesmo, antiguidade sem datas. (...) Todos os poetas, nesses momentos longos ou curtos, repetidos ou isolados, em que são realmente poetas, ouvem a voz outra. É sua e é alheia, é de ninguém e é de todos. Nada distingue o poeta dos outros homens e mulheres, salvo esses momentos raros, embora frequentes - em que, sendo ele mesmo, é outro. (PAZ, 1993, p.140)
}

É assim que podemos captar em sua poesia a constituição de um sujeito lírico dramatizado em diálogo. Nesta voz múltipla, a postura contestadora de Murilo se faz

\footnotetext{
${ }^{103}$ Versos do poema “A Tomás Luís de Victoria, Músico” de Tempo espanhol, PCP, p. 595.
} 
notar em alguns momentos nos quais mesmo diante de seu duplo engajamento, social e religioso, as reminiscências de sua crise espiritual se manifestam diante da revolta por um mundo tão afligido pela maldade. Isso ocorre em "Tentação", um poema de Poesia Liberdade no qual, como salienta Laís Correa de Araújo (2000) "ao menos a poesia pode indignar-se pela cota de ódio diariamente distribuída, pode tentar ser humana e palpável, ou exigir até a retratação de Deus" (p.96):

\author{
Diante do crucifixo \\ Eu paro pálido tremendo: \\ "Já que és o verdadeiro filho de Deus \\ Desprega a humanidade desta cruz ${ }^{104}$
}

Por meio de uma alteração estratégica, o poeta se utiliza do principal símbolo imagético do sofrimento de Cristo e o atribui à humanidade. Esta inversão é duplamente herética já que, por um lado opera uma diminuição do sofrimento de Cristo e, por outro, realiza um nivelamento de sua figura ao da própria humanidade. No entanto, ainda que o poema sugira este tom de desrespeito, o sentimento de compaixão para com os homens e o ideal de uma vida pacífica, justa e igualitária, preconizações típicas do cristianismo, permanecem firmes e inabaláveis em sua poesia sustentando seu projeto ao mesmo tempo ético e estético.

A poesia de Murilo, em sua última manifestação pública em vida, vem confirmar, então, a fidelidade do poeta aos seus princípios éticos e estéticos. O poeta múltiplo e firme em sua convicção tanto poética quanto espiritual comparece por meio dessa voz única que lhe permitiu construir uma obra fecunda e plural devido à sua capacidade extrema de abertura.

Esta abertura caracteriza sua obra desde o início já que Murilo sempre manifestou grande disponibilidade e flexibilidade no trato com a poesia: ele parodiou, satirizou, subverteu, incorporou, citou, construiu imagens ímpares e tudo isso sem se manter cativo, seja destas técnicas e procedimentos ou movimentos literários. Para ele, a liberdade parece realmente ser a primeira condição para o exercício literário. Assim, uma obra construída sobre esse alicerce, dotada desse poder de incorporação e experimentação, também se mostra essencialmente aberta. É o que o sujeito lírico diz no "Murilograma ao Criador", quando o eu-lírico indica construir sua forma dentro do tempo com total autonomia:

${ }^{104}$ PCP, p. 424. 


\section{Minha forma}

Devo eu fabricá-la no tempo

Com estas mãos autônomas:

A WORK IN PROGRESS

OPERA APERTA ${ }^{105}$

Abertura esta inerente ao próprio poema, num sentido amplo, se o encararmos como um espaço a ser adentrado por um leitor que lhe incutirá sentido; por isso, seu sentido não é único, mas sim plural, móvel, incapturável. O poema sempre convoca, assim, esse leitor, esse co-autor a desvendar não só o que está implícito no já dito, mas também o silêncio, o não dito, o imprevisto que está por detrás da superfície das palavras já que o verdadeiro poema obriga as palavras a irem mais além delas mesmas, obriga-as a dizer o indizível (PAZ, 1972). É assim que o poema guarda esse traço paradoxal de transcender a própria linguagem que lhe dá vida como observa Octavio Paz (1972):

O poema transcende a linguagem. (...) o poema é linguagem (...) mas é também mais alguma coisa. E esse algo mais é inexplicável pela linguagem, embora só possa ser alcançado por ela. Nascido da palavra, o poema desemboca em algo que a transpassa. A experiência poética é irredutível à palavra e, não obstante, só a palavra a exprime. (PAZ, 1972, p.48)

E, assim, o ato desse leitor/co-autor é o que, de fato, funda e concede existência ao poema: "queira ou não o poeta, a prova da existência de seu poema é o leitor ou ouvinte, verdadeiro depositário da obra, que, ao lê-la, recria-a e outorga-lhe sua significação final" (PAZ, 1972, p.117). Sem esse leitor, o poema seria um mero artefato verbal, pois só a sua disposição pode torná-lo, novamente, algo completo e vivo, como nos recorda muito bem Ferreira Gullar (2006): "só a carência de outro homem pode oferecer um corpo onde de novo se faça vida o que o poeta falou" (GULLAR, 2006, p.161-162).

\subsection{A mulher/o feminino}

Podemos citar como mais um dos vetores temático-formais da poesia de Murilo, a presença da mulher ou do elemento feminino envolvida numa atmosfera eróticomística, o que estabelece numa nítida tensão entre o sagrado e o profano. Segundo Bosi (2004), a palavra do poeta "entende sacralizar todos os fenômenos": por isso, "a

\footnotetext{
${ }^{105}$ PCP, p. 662.
} 
presença do eterno-feminino (a Mulher, Berenice, Eva) ora opõe-se ora une-se às aspirações religiosas" (BOSI, 2004, p.450).

$\mathrm{O}$ poeta parece conceder à mulher um lugar especial como objeto de reflexão e de investigação intensa tanto da alteridade quanto da realidade e do mundo ao seu redor. Esse debruçar-se sobre a imagem do feminino é realizado frequentemente através da contemplação erótica dos corpos e das formas femininas. Costa Lima (2002) afirma que o corpo feminino é o ícone do tempo na poesia de Murilo Mendes e que a mulher representaria, em sua carnalidade, a passagem atroz do tempo, tema principal, segundo o crítico, de $O$ Visionário (1941). Esta observação de Costa Lima pode ser facilmente verificada nos próprios títulos dos poemas deste livro nos quais a mulher aparece representada em diversas das suas fases e papéis sociais: "Mulher em todos os tempos", "A mãe do primeiro filho", "Mulher em três tempos", "Menina em quatro idades", "Duas irmãs", "Uma órfã adota a humanidade", “A namorada de Lázaro", “A noiva" "A filha do caos", dentre outros. A representação máxima deste feminino muriliano está simbolizada no poema "Jandira" do qual citamos alguns versos:

\footnotetext{
O mundo começava nos seios de Jandira.

Depois surgiram outras peças da criação: Surgiram os cabelos para cobrir o corpo, (Às vezes o braço esquerdo desaparecia no caos). E surgiram os olhos para vigiar o resto do corpo. E surgiram sereias da garganta de Jandira: $\mathrm{O}$ ar inteirinho ficou rodeado de sons Mais palpáveis do que pássaros. (...) ${ }^{106}$
}

Neste poema, o feminino toma proporções tão gigantescas que passa a reger e ser responsável pelo próprio surgimento do Universo, a cosmogênese é instaurada, assim, pela força erótica da mulher.

Entretanto, a aparição do elemento feminino pode ser identificada na poesia muriliana muito antes de $O$ Visionário, pois já no seu primeiro livro, Poemas, temos a aparição resplandecente da mulher num poema como "Perspectiva da sala de jantar", por exemplo. Neste, ao pintar uma cena típica do interior de um lar burguês com seus elementos característicos, como a presença de uma Santa Ceia e da folhinha, o eu lírico destaca a presença da filha do modesto funcionário público em toda a sua voluptuosidade que contrasta com a simplicidade e a penúria da "natureza morta da sala":

${ }^{106}$ PCP, p. 202-203. 


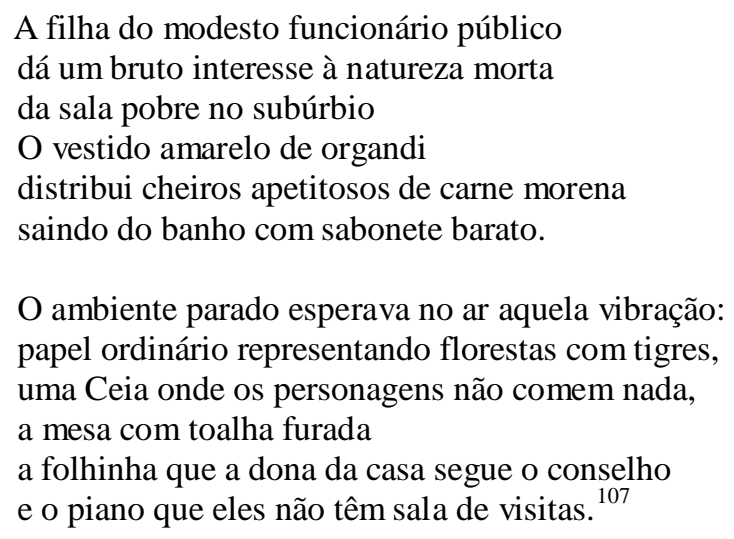

$\mathrm{Na}$ última parte deste livro, intitulada "Poemas sem tempo", a mulher é apresentada por meio de analogias e interpenetração de formas, posto que há uma profunda interseção entre o corpo feminino e uma abstração temporal. Esta abstração temporal e espacial foi, como vimos, uma das principais ideias essencialistas às quais Murilo concedia representação poética e Ismael retratava plasticamente em suas telas. No poema a seguir, "Relatividade da mulher amada", por exemplo, o sujeito lírico tomado por um imenso pesar lamenta o fato de não poder apreciar e desfrutar da companhia desta mulher como membro de sua própria família e lastima, assim, o fato dela não poder encarnar todos estes papéis ao mesmo tempo:

\footnotetext{
Eu gosto de você com uma força bruta que não entendo bem.

Gosto quase tanto como de mim.

Mas que pena você não ser também minha filha.

Que pena você não ser minha filha, minha irmã e minha mãe, [tudo ao mesmo tempo. ${ }^{108}$
}

Citemos outro poema, agora de $\mathrm{CV}$, no qual o poeta associa a temática da passagem do tempo à do feminino é Grafito para Ipólita. Nele, como ressalta Costa Lima (2002), a passagem do tempo é acompanhada no percurso da própria memória e não mais pelas deformações e metamorfoses do corpo da mulher. No poema, a figura sensual de Ipólita cujos simples passos criam o timbre, aparece associada à precocidade de voyeur do eu-lírico:

Ipólita, a putain do fim da infância

Nascera em Juiz de Fora, a família em Ferrara

Seus passos feminantes fundam o timbre.

Marcha, parece, ao som do gramofone

\footnotetext{
${ }^{107}$ PCP, p. 92.

${ }^{108}$ PCP, p. 119
} 


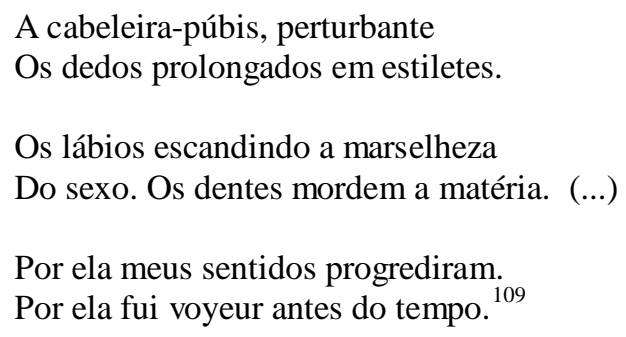

Percebe-se ao longo dos poemas de Murilo que a mulher é muitas vezes tratada pelo poeta como um ser mítico e elevado, que contém os segredos da transcendência, chave e enigma do universo, isso se deve ao fato de que ela quem carrega em seu ventre o mistério da Criação. Essa consideração da mulher como ser arquetípico abarca uma série de personagens femininas que acabam desembocando no próprio percurso dos dados autobiográficos de Murilo. A partir destes e de suas experiências o poeta constrói e apresenta, esteticamente, algumas mulheres que passaram por sua vida. No "Grafito para Ipólita" o poema se inicia com o sujeito lírico descrevendo Ipólita como a "putain do fim da infância" e ainda temos a referência de que seu nascimento ocorreu em Juiz de Fora, cidade natal de Murilo. Estes dados somados à aparição da mesma figura em seu livro de memórias, A Idade do Serrote ${ }^{110}$, nos permitem sustentar tal afirmação. Isso ocorre, também, num poema como "Pré-história", de $O$ Visionário, por exemplo. Nesse poema, recheado de imagens surreais e, por que não dizer com Júlio Castañon (1993), de um lirismo chagalliano, o eu - lírico resgata a lembrança da própria mãe do poeta $^{111}$ :
Mamãe vestida de rendas
Tocava piano no caos.
Uma noite abriu as asas
Cansada de tanto som,
Equilibrou-se no azul,
De tonta não mais olhou
Para mim, para ninguém:
Caiu no álbum de retratos ${ }^{112}$.

Nesse poema, o sujeito lírico apresenta e constrói uma história alegórica que nos remete a uma parte da própria vida pessoal de Murilo já que, conforme sabemos através

\footnotetext{
${ }^{109} \mathrm{PCP}$, p. 631-632

${ }^{110}$ A figura de Ipólita é citada quando o poeta recorda de outra prostituta da cidade na época em que ele era adolescente, "Desdêmona": "Desdêmona a vice-putain juiz-forana (a titular era Ipólita) (....)." PCP, p. 930.

111 "Trata-se de um poema que pode sem dúvida ser considerado como paralelo à pintura surrealista, apresentando mesmo um lirismo chagalliano em seus elementos visuais." (CASTAÑON, 1993, p. 36).

${ }^{112}$ PCP, p. 209.
} 
dos dados biográficos, a mãe do poeta, Elisa Valentina faleceu, "caiu no álbum de retratos", quando Murilo tinha apenas um ano de idade. Numa atmosfera menos onírica e fluida, a imagem da mãe retornará também em CV no poema "Grafito na pedra de minha mãe" em que, num misto de rememoração e especulação pessoais, o eu - lírico aborda a perda da mãe que o "catapultou" para a vida, esse território "asperoanguloso". No entanto, a morte não significa uma ausência absoluta da figura materna, já que sua mãe continua presente podendo ser resgatada através da memória por meio da imaginação e da poesia:

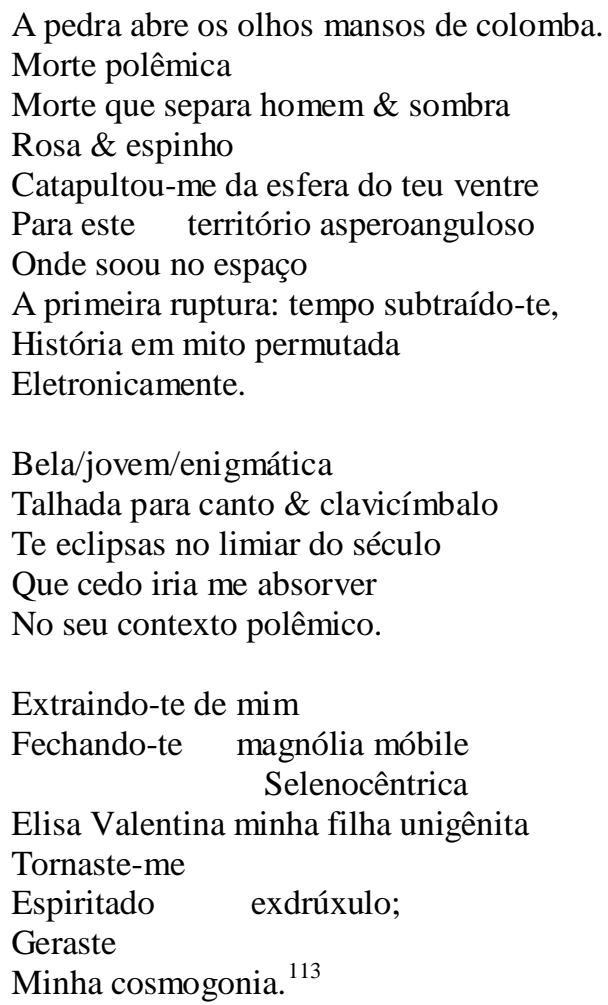

Como no poema anterior, "Pré-história", a figura da mãe é referida, também, por seus dotes ligados à sensibilidade artística, já que ela fora "talhada para canto \& clavicímbalo" como indica o eu-lírico. Ao final do poema, vale observar a inversão realizada pelo sujeito lírico que extrai sua mãe dele mesmo transformando-a, assim, em sua própria filha numa clara interseção temporal e corporal, como é próprio do Essencialismo como já dissemos.

O resgate da figura feminina por esse percurso da memória é o destaque de um livro como A Idade do Serrote, no qual Murilo recupera e recria poeticamente uma série

${ }^{113}$ PCP, p. 630. 
de figuras femininas importantes em sua vida e que, de certo modo, foram responsáveis pelo despertar de seu encantamento pelas mulheres. Por meio de uma linguagem veloz e cinematográfica, graças à utilização de uma espécie de fluxo de consciência, Murilo nos descreve suas experiências narradas, não num tempo cronológico, procedimento típico de um relato biográfico, mas sim num tempo psicológico, no qual os elementos autobiográficos aparecem recriados pelo olhar transfigurador do poeta:

Confesso que boa parte desta minha incipiente diligência cultural baseava-se
no interesse pela mulher, que remontava a tempos recuados da minha
infância. Não me contentando em ver mulheres no meu ambiente queria
ainda ter ao menos imagens fotográficas de mulheres de outros países e
outras épocas. Tratava-se não somente de fascinação pela mulher nua ou
seminua, embora estas freqüentassem minha imaginação: era a mulher na
variedade de seus tipos, sua forma, sua indumentária. (MENDES, 1994,
p.973)

A curiosidade e a fixação pela mulher manifestadas pelo poeta também estariam associadas a uma espécie de poder paradoxal de transformação que a figura feminina conteria. Deste modo, a mulher na poesia de Murilo também é um ser múltiplo que assume várias funções e apresenta diversas faces. Num momento, encontra-se nela a manifestação do poder da criação e da vida como em "Mulher" de A Poesia em Pânico:

Mulher, o mais terrível e vivo dos espectros,

Por que te alimentas de mim desde o princípio?

Em ti encontra as imagens da criação:

És pássaro e flor, pedra e onda variável... ${ }^{114}$

Já no poema de mesmo título que o anterior, mas presente em As Metamorfoses, a figura feminina é associada, não só ao seu pólo positivo, da criação e da construção, mas também, ao seu pólo negativo relacionado à destruição e à dissipação:

\footnotetext{
Mulher

Ora opaca ora translúcida

Submarina ou vegetal

Assume todas as formas,

Desposas o movimento.

(...)

Tu és na verdade, mulher,

Construção e destruição. ${ }^{115}$
}

\footnotetext{
${ }^{114}$ PCP, p. 290-291.

${ }^{115}$ PCP, p. 350.
} 
Além das imagens da mãe e da amada, a mitificação do feminino encontra sua mais alta representação na figura da Virgem Maria. Ela tem o seu lugar garantido na galeria das figuras femininas na poesia de Murilo aparecendo em diversos poemas, todavia, figuras femininas da mitologia pagã também podem ser notadas na poesia muriliana. Isso ocorre com o mito de Lilith que embora tenha origens judaico-cristãs já que Lilith teria sido a primeira mulher de Adão tendo sido criada diretamente por Deus, passou por uma espécie de perda deste seu caráter místico já que ela não correspondeu às expectativas divinas. Isso ocorre porque Lilith rebelou-se contra Adão e contra Deus questionando os seus poderes o que transformou sua figura num símbolo da mulher insubmissa. Este é evocado no poema "Revelação", no qual, por meio de uma atmosfera surrealista, na qual os pianos e os clarins marcham pela manhã, essa mulher rebelde e desobediente utiliza seus poderes sobre os homens:

\author{
A dona da cidade maldita \\ Penteia os cabelos no relâmpago \\ Ó filhos morenos dos mares do sul \\ Que vos suicidais pelo seu olhar, \\ Sou vosso cúmplice e vosso irmão: \\ Somos todos sua vítimas. \\ Que nos adiantam os pianos \\ E os clarins marchando na manhã? \\ Espero o fogo, o fogo sobre nós. \\ Quem troca seu corpo por um pão? \\ Pedimos água e nos dão veneno. \\ A dona da cidade maldita. \\ Lilith, anda solta ao microfone. ${ }^{116}$
}

Esse movimento, de unir o sublime/maravilhoso ao rebaixado, o mito ao cotidiano mais prosaico, é um movimento característico da poesia muriliana e em muito se deve à sua ligação com o surrealismo. Por meio das aproximações insólitas Murilo transporta o mito para o cotidiano criando imagens inusitadas como a de Lilith "solta ao microfone". Como salienta José Guilherme Merquior (1996) Murilo criou em sua poesia uma espécie de poética do visionário na qual convivem naturalmente tanto o insólito, o maravilhoso quanto o vulgar e o prosaico. No caso de Murilo, essa realização foi numerosa e muito fértil por um período de tempo considerável, o que nos possibilita afirmar, segundo Merquior (1996) ter sido o poeta não só um surrealista, mas um surrealista realizado.

\footnotetext{
${ }^{116} P C P$, p. $324-325$.
} 
Como já viemos salientando, o surrealismo acompanhará Murilo do início até o fim em sua trajetória. Não foi uma simples adesão a uma escola/movimento, mas está relacionada a algo mais profundo, a uma necessidade de sua linguagem poética que sempre se interessou e defendeu a plena supremacia das potencialidades da imaginação. Em CV, a presença do surrealismo se faz notar em algumas imagens inusitadas e insólitas que o poeta dissemina ao longo do livro. Em "Murilograma a Leopardi" lemos esses versos de clara expressão surrealista:

\author{
A noite desossada \\ Te incorresponde \\ Pões a nu sem aspas \\ $\mathrm{O}$ inelegante sofrimento. \\ Atinges a colina com palavras. \\ Adivinhas talvez \\ A próxima aurora elétrica \\ Desligando-nos do teto \\ Das Ideias, antigo ${ }^{117}$
}

Em outros momentos do livro são as técnicas e os recursos formais que o poeta utiliza que chamam a atenção para a presença do surrealismo em CV como as já mencionadas utilizações dos recursos da colagem e da montagem, por exemplo. Murilo chega a intitular um dos poemas do livro de "Colagem para Drummond" que é composto da seguinte forma: nas primeiras duas estrofes cada linha é constituída por dois versos, sendo que no primeiro sempre ocorre a referência a Itabira ao final e no segundo esta se faz com o próprio nome de Drummond, de modo que as palavras que antecedem estas referências geralmente são aparentadas por alguma afinidade sonora e, em certos momentos, são idênticas. Já nas duas últimas estrofes, cada linha também é constituída por dois versos, sendo que nos primeiros há a recorrência do nome de Drummond ao final, enquanto nos segundos a referência é realizada com o nome do país:

O ferro de Itabira. As farpas de Drummond.

As tropas de Itabira. Os tropos de Drummond.

Os tetos de Itabira. O tato de Drummond.

As madres de Itabira. Os mortos de Drummond.

Os podres de Itabira. Os padres de Drummond.

Os couros de Itabira. A cara de Drummond.

O frio de Itabira. O frio de Drummond.

As fotos de Itabira. Os fatos de Drummond. (...)

O enigma de Drummond. O enigma do Brasil.

${ }^{117}$ PCP, p. 670. 
As minas de Drummond. As minas do Brasil.

O norte de Drummond. O norte do Brasil.

As noites de Drummond. A noite do Brasil.

A época de Drummond. A épica do Brasil.

$\mathrm{O}$ áporo de Drummond. O áporo do Brasil. (...) ${ }^{118}$

Assim, na superposição de associações sonoras e intertextuais referentes à poesia de Drummond, como a citação do ferro e da foto de Itabira mencionados no poema drummondiano "Confidência do Itabirano", o eu - lírico transforma o poema, ao mesmo tempo, numa homenagem à Drummond e numa demonstração explícita do processo da colagem em poesia.

Como já cremos ter deixado claro, não só o referencial surrealista, mas também, o elemento religioso não serão abandonados por Murilo ao longo de sua trajetória, podendo ser verificados até a sua última produção poética em vida que é CV. No poema "Murilograma a N.S.J.C.”, esses dois referenciais aparecem interligados quando o poeta tece e enumera várias metáforas numa tentativa de definição de Jesus Cristo. Convém retomar o fato apontado por Leo Spitzer (1955) das raízes religiosas do estilo enumerativo, pois a ocorrência deste recurso na poesia de Murilo também estaria fixada neste elemento religioso. Em "Murilograma a N.S.J.C.", o poeta tenta apreender uma visão geral da figura de Cristo por meio da citação de diversos pontos de vista ${ }^{119}$ que vêm demarcados e separados por meio do recurso gráfico do ponto em negrito de modo que cada verso atuaria como uma espécie de estrofe extremamente condensada:

$\underline{\mathrm{A}}$

Peixe triangular. Pedra angular.

Pastor da eternidade. Herói do tempo.

Sol cooperativo. Oculto em catacumba.

Único ator de milmãos. Teatro aberto. ${ }^{120}$

\footnotetext{
${ }^{118}$ PCP, p. 712.

${ }^{119}$ A propósito do recurso das bolinhas pretas nos textos murilianos, Murilo Marcondes de Moura (1993) indica que elas revelariam um modo de ver descontínuo, porém interessado em percorrer a totalidade do objeto a ser conhecido/analisado.

${ }^{120}$ PCP, p. 662-663.
} 
Convém recordar que a metáfora, como já lembramos aqui, foi um dos principais meios de criação da imagética insólita praticada pelos poetas surrealistas e também por Murilo. No entanto, outras técnicas e procedimentos foram colocados em prática pelos surrealistas e, conforme já aludimos, as técnicas combinatórias primeiramente empregadas nas artes plásticas foram notadamente utilizadas.

Segundo Murilo Marcondes de Moura (1995), o efeito poético que resulta da utilização dessas técnicas não reside na complexidade dos meios utilizados, mas sim, na combinação que gera a surpresa. A tensão entre a combinação insólita de palavras provoca o que o formalista russo Victor Chklovsky (1978) denominou de "estranhamento" em seu consagrado texto "A arte como procedimento". Para o estudioso russo, a finalidade da arte é "dar a sensação do objeto como visão e não como reconhecimento" (CHKLOVSKY, 1978, p. 45), por isso, o procedimento primordial da arte é o da "singularização dos objetos", pois obscurecendo-se a forma aumenta-se a dificuldade e, consequentemente, a duração da percepção.

A criação dessas imagens insólitas de teor visionário salienta outra característica marcante da poesia de Murilo Mendes e que também não será abandonada ao longo de sua trajetória: a visualidade presente em seus poemas sob diversos aspectos. Reservamos para o próximo subcapítulo o comentário sobre mais essa especificidade de sua poesia.

\subsection{A imagem/a visualidade}

O sujeito lírico quando anuncia ter sido um voyeur precoce por causa de Ipólita demarca mais um dos vetores/motivos recorrentes da poética muriliana: a questão do olhar e da visualidade, que parece ter, desde sempre, fascinado e despertado o seu interesse. Como observa muito bem Arlindo Daibert (1995), Murilo parece ter tido uma capacidade ímpar de perceber o mundo através da visão de modo que essa sua perspectiva lhe proporcionou uma apreensão eminentemente plástica da existência.

O exame da questão da visualidade na poesia de Murilo aponta para vertentes distintas, conforme já verificou Júlio Castañon Guimarães (1993). De um lado, temos a ampla utilização que o poeta realizou da imagem em poesia e, por outro lado, a própria 
presença das artes visuais seja nos títulos de poemas que remetem a alguma técnica ou gênero desta arte, ou ainda na referência a algum artista plástico específico. Vale recordar, também, que Murilo sempre esteve interessado na manipulação da palavra como extrato gráfico.

Esse fascínio pela questão imagética está presente na poesia de Murilo desde o seu primeiro livro, Poemas, que possui como título do segundo capítulo justamente o vocábulo "ângulos", que se refere à visualidade. Outras alusões podem ser percebidas no título de alguns poemas disseminados pelo volume, nos quais o poeta recorre à terminologia do mundo da pintura como em "Aquarela" e "Marinha", por exemplo.

O outro modo pelo qual se estabelece essa relação está, com apontou Castañon, nas referências que Murilo realiza a algum pintor específico homenageando-o em seus poemas. Nesse caso, o poema parece querer captar, descrever algum quadro ou apresentar, numa espécie de suma geral, um panorama da obra do artista plástico homenageado. Isso ocorre, por exemplo, no poema "Vermeer de Delft", de Poesia Liberdade:

\author{
É a manhã no copo; \\ Tempo de decifrar o mapa, \\ De abrir as cortinas onde o sol frio nasce, \\ De ler uma carta perturbadora \\ Que veio pela galera da China: \\ Até que a lição do cravo \\ Através dos seus cristais \\ Restitui a inocência ${ }^{121}$.
}

Como observou Arlindo Daibert (1995), o poema constrói-se a partir da enumeração precisa dos principais temas e imagens recorrentes nos quadros de Vermeer: as cortinas, o mapa, a carta, o copo, elementos que são alinhados com "o rigor de imagens cinematográficas em oito versos-síntese” (p. 96).

É curioso observar o fato de que, quando Murilo descreve um quadro específico, a imagem pictórica torna-se o tema poético central numa espécie de entrelaçamento entre os dois universos, o da imagem e o da palavra poética. Isso ocorre no poema "Harpa-Sofá (Um Quadro de Vieira da Silva)", de Mundo Enigma, por exemplo. Vale mencionar que esse poema, além da motivação de apreço artístico pela obra alheia,

${ }^{121}$ PCP, p.406. 
contém uma clara referência afetiva já que Murilo foi amigo da pintora portuguesa Maria Helena Vieira da Silva ${ }^{122}$ :

\author{
Repousa na harpa-sofá \\ A mulher com o filho pródigo, \\ Sirene bleue nonchalante, \\ Veio da terra de Siena \\ Talvez medieval ou chinesa. \\ Eis o grande no minúsculo: \\ Da minha infância é que veio, \\ Ou do tempo que virá ${ }^{123}$.
}

No poema em questão, o eu-lírico descreve de forma extremamente condensada e alegórica a inofensiva imagem pintada no quadro: a de uma mulher que segura uma criança num sofá com contornos similares ao do instrumento musical. Ao recriar essa imagem, Murilo abre vias para o insólito que, de resto, vem indicado pelo título do quadro ao qual o poema se refere e que, por sua vez, transforma-se no titulo do poema no qual o sofá não é um mero utensílio doméstico, mas também um instrumento musical, uma "harpa-sofá". Assim, a mulher que sobre ele se senta pode, igualmente, ser algo a mais do que uma simples mulher, pois ela assume nas palavras de Murilo uma personalidade diversa e inconclusa. Seu tempo também não é claro, vindo da própria infância do eu - lírico ou do tempo que ainda está por vir e assim o quadro de Vieira da Silva ressurge construído e atualizado via palavra.

Vale recordar, com Arlindo Daibert (1995), que esse movimento, da influência das artes plásticas sobre a literatura, também foi sentido de forma inversa, já que, assim como a imagem invadiu a linguagem poética, a palavra adentrou o espaço do quadro de diversas formas. Isso ocorreu, num primeiro momento, com o uso do recurso da colagem de fragmentos de jornais, partituras musicais, embalagens de produtos, bilhetes de metrô, programas de cinema e teatro etc e, posteriormente, com a utilização de palavras estampadas e pintadas diretamente sobre as telas. Segundo Daibert (1995):

\footnotetext{
A palavra ou o texto escrito transformam-se em grafismos ilegíveis próximos da garatuja infantil ou dos grafitti anônimos dos muros. Um texto com grau zero de leitura; uma escrita paródica aludindo à falência dos sistemas de comunicação. Essas primeiras manifestações trazem ainda uma forte marca das experiências com a escrita automática dos surrealistas. (DAIBERT, 1995, p. 80)
}

\footnotetext{
${ }^{122}$ A amizade de Murilo com a artista plástica remonta aos anos 40 quando ela e seu esposo, o também artista plástico, Arpad Szenes, se refugiaram no Brasil por ocasião da Segunda Guerra Mundial.

${ }^{123}$ PCP, p. 377.
} 
Ora, a alusão do artista plástico ao grafite nos remete imediatamente a CV e aos grafitos murilianos, forma específica que o poeta encontrou para manusear, tanto a palavra, quanto os aspectos imagéticos da linguagem poética. Nos grafitos, mas também nos murilogramas, transbordam as referências a pintores, que são citados e homenageados em diversos poemas. Só para citar alguns deles, temos: Van Gogh, Piranesi, Giuseppe Capogrossi, Anton Pevsner e Paollo Ucello. Vale a pena comentar o grafito em homenagem a esse último, "Grafito para Paolo Ucello", no qual o poeta tenta recriar uma totalidade da obra do pintor florentino captando-a nos seus elementos mais recorrentes. No entanto, ainda que o poeta apresente uma suma da obra do pintor florentino, há no poema uma menção implícita a um quadro específico desse pintor que é "A batalha de San Romano", a única na qual, afirma o eu-lírico, aceitaria estar incluído figurar, talvez pelo fato de que a pintura, como ele afirma mais adiante no mesmo poema, mesmo que num quadro no qual se retrata uma guerra, sabe concedera paz necessária ao espectador:

\author{
Talvez a única batalha \\ Onde eu aceitasse figurar \\ Para contorná-la depois \\ Redimensionada pela tua ótica: \\ Perspectiva pacífica. \\ Na tua batalha entro \\ Da tua batalha saio \\ Não mato ninguém \\ Nem fui morto. \\ À tua batalha volto \\ Siderado não-ferido \\ Pela Coisa épica \\ Com esta paz que a pintura \\ Mais que pedra ou som \\ Sabe dar. ${ }^{124}$
}

É assim que muitos poemas do livro se mostram verdadeiros ensaios críticos em forma de versos nos quais o poeta ressalta os atributos específicos dos artistas aos quais dedica os poemas. Isso ocorre tanto com os artistas plásticos homenageados quanto com alguns compositores. Merece destaque, neste sentido, o murilograma dedicado ao músico da escola dodecafônica, Anton Webern:

\footnotetext{
${ }^{124}$ PCP, p. 650-651.
} 
O quadrado inserido no redondo/ Alude a um microcosmo portátil./ Tempo matemático que se autodefine/ Por fragmentos paralelos de minuto:/ Contidos em prismas alinhando-se na partitura./ Decanta-se Guillaume Dufay. / O som da praxis./ A praxis do som.

Fuzilando-te/Anton Webern/Por engano/Fuzilaram quem?/Ofereceram-se uma falsa vista/E uma audição fantasma do mundo./Tal ocisão contraise/Num simulacro de morte./Mas tu/Intacto Anton Webern/És concreto./Teu espaço desaprende o vôo./Disseste o funda-mental.

Não podes contactar no paralém/O pulso da cidade arrítmica./Nem podes captar/ As atuais sirenes de alarme/Antecipando o deflagrar do século futuro./Não somos fuzilados por engano./Je EST UN AUTRE ${ }^{125}$.

O que chama a atenção de imediato, já pela visualização do poema, é sua forma geral, mais aparentada à prosa do que à poesia devido à forma cursiva de escrita ${ }^{126}$. Os versos/frases são separados por barras divisórias, indicando, mais uma vez, a importância desse tipo de elemento gráfico na poesia de Murilo, que aparece em destaque em CV. Segundo Castañon (1993), o simples uso das barras já apontaria um ritmo a meio caminho entre o da prosa e o da poesia.

O primeiro bloco do poema indica peculiaridades da música de Webern ${ }^{127}$, com alusões à sua concisão, rigor e inovação; por isso, como sugere Castañon (1993), encontra-se nesta parte significativa presença de vocábulos ligados à geometria e à matemática como: quadrado, redondo, tempo matemático, paralelos e prismas. Tal recorrência apontaria para a concepção da estrutura racionalizada e simétrica da música de Webern, que explorou novas dimensões da expressão musical, especificamente a atonalidade, renunciando às regras de harmonia e de tonalidade clássicas.

Júlio Castañon (1993) observa que as duas últimas frases do primeiro bloco (que são formadas pelas mesmas palavras que se invertem de um segmento para o outro), indicariam um ponto principal do próprio caráter de construção da música weberniana que se mostra avessa a qualquer possibilidade de referenciação, levando aos extremos

\footnotetext{
${ }^{125} \mathrm{PCP}$, p.696.

${ }^{126}$ Vale lembrar que a prosa poética foi um gênero muito praticado por Murilo, como já tivemos a ocasião de mencionar.

127 Compositor da escola dodecafônica, Webern foi uma grande inspiração para os poetas concretistas brasileiros devido a uma série de inovações musicais que realizou e que os poetas concretos incorporaram e transfundiram para a poesia. Lívio Tragtenberg (1991) menciona, por exemplo, a semelhança entre uma peça para coro misto e orquestra de Webern intitulada Das Augenlicht e a formulação do texto Galáxias do poeta concretista Haroldo de Campos. Para Tragtenberg (1991), estas obras seriam verdadeiros caleidoscópios onde os elementos constitutivos que fazem parte da microforma englobam as demais já como elementos de macroforma.
} 
não apenas a tradição, - por isso a referência ao compositor renascentista no verso "Decanta-se Guillaume Dufay" - mas a própria dimensão não-referencial da música.

$\mathrm{O}$ segundo bloco do poema refere-se à morte por equívoco do músico ${ }^{128}$ e indica a sua continuidade e sua importância no panorama da música moderna: como se diz no poema, ele disse o "funda-mental". Já entre o segundo e o terceiro bloco há uma espécie de inversão, como indica Castañon (1993), posto que nos primeiros segmentos do segundo bloco lê-se: "Fuzilando-te/Anton Webern/Por engano/Fuzilaram quem?", enquanto nos dois últimos segmentos do terceiro bloco: "Não somos fuzilados por engano/Je EST UN AUTRE." Esse último verso destacado em caixa alta apresenta mais uma das muitas citações que Murilo realiza em CV como já apontamos. O verso final do poema que também é a sua epígrafe (o que indica aquela estrutura circular praticada por Murilo em outros momentos do livro) é tomado de empréstimo a Rimbaud. Essa citação indica, sobretudo, aquela polifonia mistura de vozes que o poeta realiza em $\mathrm{CV}$ ao tomar de empréstimo as vozes alheias para compor consigo sua confluência poética final. Assim, passando pela descoberta da alteridade que o verso rimbaldiano tão bem sintetiza, Murilo, em CV, deságua "numa integral pulverização do sujeito poético sediada num processo de multiplicação-fragmentação do Eu claramente modernista" (FRIAS, 2002, p.14).

Recordemos que ao final do poema "Texto de Informação" há a menção à influência que certos artistas exerceram sobre Murilo, dessas vozes que ele assimilou em sua obra, dentre as quais se encontra, justamente, o nome de Webern: "Webernizeime”. Segundo Joana Matos Frias (2002), a assimilação do compositor da Escola de Viena clarifica e confere substrato sólido a uma das vertentes mais significativas da poesia muriliana: o seu frequentemente criticado caráter amelódico, que o poeta assumiu com indisfarçado prazer $^{129}$.

O apelo ao poder visual da linguagem é utilizado por Murilo em outros livros que já trazem essa referência desde o próprio título, como é o caso de Contemplação de Ouro Preto (1954) e o já citado por nós, O Visionário. Neste último, em especial, Castañon (1993) sublinha que a visão seria a base da elaboração poética, daí a menção

\footnotetext{
${ }^{128}$ Com o fim da Segunda Guerra, o músico mudou-se com a família para uma casa de campo em Mittersill e confundido com seu genro, que era suspeito de atividades ilegais, foi morto em 15 de setembro de 1945 por um soldado norte-americano durante a invasão dos Aliados.

129 "Persegui sempre mais a musicalidade que a sonoridade; evitei o mais possível a ordem inversa; procurei muitas vezes obter o ritmo sincopado, a quebra violenta do metro, porque isso se acha de acordo com a nossa atual predisposição auditiva; certos versos meus soa os de alguém que ouviu muito Schonberg, Stravinsky, Alban Berg e o jazz.” Murilo Mendes apud Joana Matos Frias, 2002, p. 59.
} 
excessiva do verbo ver ao longo de todo o livro, bem como de outros do mesmo campo semântico como olhar e contemplar, por exemplo. Como exemplo, podemos citar os trechos dos poemas "Dilatação da poesia" e "Formas Alternadas", respectivamente:

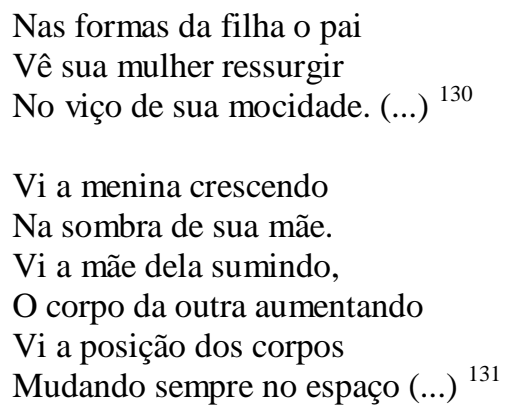

Observa-se neste livro que o olhar enquanto ato físico pode indicar e implicar questionamentos de ordem metafísica. É assim que idéias essencialistas tomam forma num poema como "Juízo final dos olhos":

Teus olhos vão ser julgados
Com clemência bem menor
Do que o resto do teu corpo
Teus olhos pousaram demais
Nos seios e nos quadris,
Eles pousaram de menos
Nos outros olhos que existe
Aqui neste mundo de Deus ${ }^{132}$.

Outras relações com a questão visual podem ser verificadas na poesia muriliana não apenas no que diz respeito à linguagem verbal do poema, mas também aos seus aspectos gráficos. É o caso dos sinais gráficos que aparecem em vários poemas de livros como Tempo Espanhol e mesmo em CV. Dentre outros sinais podemos ressaltar: o caso do \&, que substitui a conjunção "e"; do círculo em negrito (•) que separa as estrofes ou conjuntos de versos de certos poemas; a barra (/) que ocorre no interior de certos versos e também nos textos de prosa; o sinal de igual (=); o hífen (-); o sinal de adição (+) etc. Outro agente gráfico importante, principalmente nos poemas de $C V$, é a utilização do espaço da página na qual o poema se inscreve como elemento significativo.

Vale recordar que a consideração das qualidades espaciais do poema tem como texto inaugural o Un Coup de Dés Jamais n'Abolira le Hasard ${ }^{133}$ do poeta francês

\footnotetext{
${ }^{130}$ PCP, p. 199.

131 PCP, p. 200.

132 PCP, p. 205.
} 
Mallarmé, uma referência fundamental para Murilo. Podemos verificar essa utilização do espaço como elemento estruturador em "Grafito num muro de Roma", poema no qual, a certa altura, o espaço no interior dos versos representa visualmente o roer de que fala o próprio poema, como já sublinhou Júlio Castañon (1993):

\author{
Um verme enorme rói \\ Um verme inerme rói \\ Qualquer julgamento \\ Presente futuro \\ Pessoal universal \\ Miguelangelesco ou não ${ }^{134}$.
}

Esse poema abre a seção dos "grafitos" tendo sido antecedido por um único poema, "Exergo", exatamente o primeiro e o último poema do livro, exceto por algumas alterações. A primeira modificação diz respeito ao título, já que o poema que inicia a primeira parte intitula-se "Exergo", que significa o espaço em moedas ou medalhas em que se grava data ou outra informação, enquanto o poema que encerra tem como título "Final e Começo". A segunda alteração é que no poema que fecha a primeira parte há o acréscimo do verso "Fim?". Essa repetição do mesmo poema nas extremidades do livro denotaria, segundo Joana Matos Frias (1999), a organização da obra numa estrutura circular, tal como outras obras de outros escritores modernos, como por exemplo, o célebre poema já citado de Mallarmé, Un coup de Dés, cujas primeiras palavras também são as últimas; ou mesmo o livro mais experimental de James Joyce, Finnegans Wake, no qual a frase inicial é uma continuação da última. Essa circularidade que encontramos nessas obras modernas e em CV nos remete ao que Octavio Paz (1982) menciona em $O$ Arco e a Lira ao indicar que a figura que melhor representaria o poema é, justamente, o círculo. Desse modo, ao contrário da prosa, uma construção linear e progressiva que pode ser associada a uma linha reta, ao poema é inerente uma espécie de autossuficiência na qual o fim é também um princípio que se volta sobre si mesmo e se recria constantemente:

A figura geométrica que simboliza a prosa é a linha: reta, sinuosa, espiralada, ziguezagueante, mas sempre para diante e com uma meta bem precisa. Daí que os arquétipos da prosa sejam o discurso e a narrativa, a especulação e a história. O poema, pelo contrário, apresenta-se como um círculo ou uma

\footnotetext{
${ }^{133}$ Não só este, mais outros aspectos inaugurados pelo poema de Mallarmé foram assimilados por Murilo como, por exemplo, a interiorização da crítica no interior do poema, a estrutura circular e especular, que já apontamos neste capítulo.

${ }_{134}^{13} \mathrm{PCP}$, p. 627.
} 
esfera - algo que se fecha em si mesmo, universo autônomo no qual o fim também é um principio que volta, se repete e se recria. (PAZ, 1982, p. 83)

No poema "Exergo", o eu-lírico refere-se a Orfeu, um herói grego tradicionalmente associado à figura do poeta, chegando a criar um termo que dê conta do árduo papel desse poeta/Orfeu, qual seja, o verbo "orfar", conjugado ludicamente nos dois últimos versos:

\author{
Lacerado pelas palavras-bacantes \\ Visíveis tácteis audíveis \\ Orfeu \\ Impede mesmo assim sua diáspora \\ Mantendo-lhes o nervo \& a ságoma \\ Orfeu Orftu Orfele \\ Orfnós Orfvós Orfeles ${ }^{135}$
}

Orfeu, um dos mitos mais caros a Murilo, encontra-se, nesse poema, numa verdadeira luta com as palavras, o que aponta para aquela concepção de poesia como esforço oposta à ideia de inspiração, visão apresentada por outros poetas modernos. Vemos que retorna, aqui, a questão da autorreflexividade e do debate entre uma poesia de construção e uma poesia de inspiração das quais já tratamos anteriormente. O poeta dilacerado pelas "palavras bacantes", consegue evitar-lhes a dispersão e mantendo-lhes o nervo e a "ságoma" (palavra italiana que designa "moldura", ou no caso do poema, "perfill”), ou seja, alguma coisa escapa já que ele só consegue manter a moldura, o perfil ficando as "palavras-bacantes" responsáveis pelo resto. Vale recordar o poema "O lutador" de Drummmond no qual o eu - lírico expressa a mesma ideia descrita em "Exergo", da luta do poeta com as palavras apresentando uma visão do trabalho poético como uma batalha contínua entre o poeta e as palavras, combate desde o início perdido já que é impossível ao poeta exercer uma dominação absoluta sobre as palavras/a linguagem.

O experimentalismo radical de Murilo é visto por Joana Matos Frias (1999) como uma das peculiaridades de $\mathrm{CV}$, que ocupa uma posição bem particular na trajetória de Murilo, pois surge, ao mesmo tempo, como o ponto-limite de um experimentalismo com a linguagem e como um ponto de chegada de uma obra em incansável metamorfose.

${ }^{135}$ PCP, p. 625. 
No entanto, podemos dizer que subjaz a essa experimentação radical e lúcida que Murilo empreende nessa sua última obra poética uma base sólida construída ao longo de toda a sua trajetória por um poeta que sempre concedeu atenção e cuidado à feitura poética. De resto, se partirmos de um ponto de vista como o de Michael Hamburguer (2007) podemos considerar que todo poema é experimental ou não valeria a pena ser escrito, pois:

\begin{abstract}
se um verdadeiro poeta pudesse prever que tipo de poesia haveria de escrever no ano seguinte, ou na década seguinte, não haveria necessidade de ele escrevê-la (...) a poesia é uma busca e uma descoberta do imprevisível, segundo limites e condições além do controle do poeta, porque eles dependem da complexa interação de processos exteriores e interiores. (HAMBURGUER, 2007, p.173-174)
\end{abstract}

A essa altura das discussões, vale a pena voltar a uma questão importante e muito polêmica na recepção crítica de Murilo Mendes, particularmente no que concerne a CV: a sua ligação com a poesia concreta.

Essa ligação é inegável pelo simples fato de que alguns poemas de CV foram publicados anteriormente no órgão porta-voz da poesia concreta, a revista Invenção, precisamente na sua edição de número 5, que abrangeu o período de novembro de 1966 a janeiro de 1967. Entretanto, esta influência que Murilo teria sofrido do concretismo pode ser relativizada sob diversos aspectos. Ela se faz notar na incorporação de todo um repertório de procedimentos e técnicas tidas como concretistas. Entretanto, os concretos, por sua vez, já se valiam de todo um repertório de procedimentos e técnicas adotados por outros escritores e poetas modernos, justamente os eleitos pelos concretistas para compor o cânone do movimento.

Joana Matos Frias (2002) nos recorda que certos tipos de procedimentos empregados por Murilo em CV, como a exploração de uma sintaxe paralelística ou dos jogos de palavras fundados na homonímia e na paronímia, também foram explorados por vários autores franceses de procedência surrealista e mesmo alguns que do surrealismo se afastaram posteriormente como: Robert Desnos, Benjamin Péret, Jacques Prévert, Henri Michaux, Raymond Queneau. Como Murilo tinha amplo conhecimento das obras de autores franceses, notadamente dos surrealistas, também não se pode ignorar e anular a importância que estes autores tiveram para o poeta.

Sobre a questão da influência do concretismo na poesia de Murilo, talvez valesse a pena inverter o olhar e observar a influência contrária, do poeta sobre o Concretismo. Murilo Mendes, num primeiro momento, foi uma forte influência para os poetas 
concretistas. Num artigo-testemunho, Os poetas concretos e João Cabral de Melo Neto, Haroldo de Campos (2000) revela os motivos para a influência de João Cabral e Murilo Mendes na poesia concreta. O primeiro, pela engenharia poética; Murilo, pela sua obra plástica e substantiva. Por esta plasticidade, o próprio João Cabral, que também foi uma clara influência para Murilo, já atestou seu tributo à poesia muriliana: "sua poesia me foi sempre mestra, pela plasticidade e novidade da imagem. Sobretudo foi ela quem me ensinou a dar precedência à imagem sobre a mensagem, do plástico sobre o discursivo". ${ }^{136}$ É interessante notar que houve entre os dois poetas, Murilo e João Cabral, todo um jogo de influências recíprocas e também de divergências no que tange a concepções poéticas que, no entanto, não impossibilitaram um diálogo frutífero entre as suas obras. Em CV, a maior parte do tempo o outro é percebido por Murilo como uma linguagem próxima à sua devido a alguma característica em comum. Isso não será diferente no poema em homenagem a João Cabral, "Murilograma a João Cabral de Melo Neto", no qual o eu - lírico observa as suas semelhanças com a poesia cabralina ao mesmo tempo em que a traduz como uma linguagem diversa da sua. Assim, na primeira parte do poema alternam-se as aproximações entre as duas poéticas pela utilização do "comigo e contigo", e as diferenças entre as mesmas com o uso da expressão "entre mim e ti". Deste modo, o eu - lírico indica a pátria comum dos poetas e o interesse que os liga à Espanha e seus signos, como a pintura de Velázquez, por exemplo. Em seguida, aponta, também, algumas peculiaridades que os separam como as características da geografia natal, da caatinga nordestina e das montanhas mineiras:

\footnotetext{
1

Comigo e contigo o Brasil.

Comigo e contigo a Espanha.

Entre mim e ti a caatinga.

Entre mim e ti a montanha.

Comigo e contigo Velázquez.

Graciliano, o moriles.

Entre mim e ti o barroco,

A cruz, Antonio Gaudí. ${ }^{137}$
}

Retornando à questão da influência concretista em Murilo, como indica Irene Miranda Franco (2002), o interesse do poeta pelas vanguardas artísticas sempre foi muito grande, o que explica essa sua aproximação com o concretismo, mas não faz de

\footnotetext{
${ }^{136}$ João Cabral de Melo Neto apud Haroldo de Campos, 1970 p. 55.

137 PCP, p. 691.
} 
CV, um livro de poesia concreta. As próprias declarações do poeta em relação a isso são polêmicas e ambivalentes. Em 1961, numa entrevista concedida ao Jornal do Brasil, o poeta responde à questão "Sente-se influenciado pelo Concretismo?" com um veemente "Não". Contudo, na mesma entrevista acrescenta: "constato a crise da poesia, por esgotamento dos esquemas (...). Neste ponto, minha posição, de certo modo, coincide com a dos concretistas" ${ }^{138}$. Alguns anos mais tarde, numa carta a Laís Corrêa de Araújo (2000), o poeta assume que CV é um dos seus livros maiores e resume a experiência de três gerações, inclusive a dos concretos e da poesia práxis.

No entanto, embora exista essa confluência é possível notar na recepção crítica de Murilo certa rejeição desta sua aproximação com a poesia concreta. Encontramos esta desaprovação num crítico como Davi Arrigucci Jr. (2000), por exemplo, que não participa de nenhuma das duas tendências críticas por nós analisadas neste trabalho. Arrigucci Jr. desqualifica completamente CV e boa parte da produção muriliana por sua denotatividade explícita e pura preocupação formal chegando a acusar o poeta de puro modismo:

nos poucos momentos em que nele predominam apenas o senso formal da
construção, como em alguns poemas de Convergência, onde parece buscar,
pelo construtivismo declarado, pelos jogos de paronomásticos e
trocadilhescos da sonoridade, os modelos de uma vanguarda tardia,
inteiramente anacrônica para quem vinha de antes e não precisava de
aggiornamento na década de 60 (...). (ARRIGUCCI JR., 2000, p. 119)

Não consideramos que Murilo se aproximou ao concretismo como busca de uma aceitação tardia nos meios literários contrariando esse posicionamento radical de Arrigucci Jr.. De resto, o próprio crítico nos proporciona um argumento relevante contra sua visão ao mencionar que um dos pressupostos da poesia moderna é justamente a liberdade de criação do poeta e sua insubmissão a padrões coercivos impostos por alguma norma ou movimento literário. Assim sendo, o poeta moderno, como possuidor desta liberdade, pode seguir ou mesmo romper com quaisquer padrões externos ou mesmo com normas outrora criadas por si próprio, na medida em que persegue, como Murilo, uma maturidade poética/“meta múltipla" marcada por um desejo de constante renovação. Na verdade, nos interstícios do texto de Arrigucci Jr., percebemos que sua crítica não está direcionada à poesia de Murilo Mendes, que ele analisa e interpreta com extremo rigor, captando e redescobrindo sutilezas e alicerces fundamentais de sua poesia, mas sim à poesia concreta e seus principais representantes.

\footnotetext{
${ }^{138}$ Murilo Mendes apud Joana Matos Frias, 2002, p. 64.
} 
A propósito convém mencionar que outros críticos, não só Arrigucci Jr., desvalorizam CV e parte da produção poética de Murilo. Para Bruno Tolentino (1995), por exemplo, Murilo teria, em $\mathrm{CV}$, mais precisamente nos seus murilogramas, se entregado a meras ingenuidades e cacoetes poéticos. Por sua vez, o crítico Wilson Martins (1995) considera CV um livro anacrônico, realizado com o espírito dos anos 30, mas escrito com a linguagem dos anos 60. O mesmo crítico vai ainda mais longe quando indica que após a década de 30 a obra de Murilo teria entrado num processo irrecuperável de decadência e senescência literária. Outro crítico que manifesta a desaprovação de CV é José Paulo Paes, para quem esse livro "com suas elocubrações metapoéticas em torno da palavra e não mais da Palavra, nos traz um Murilo ainda inventivo, virtuoso mesmo, se quiserem. Mas, perdoem-me, não é mais o 'meu' Murilo.” (PAES, 1997, p. 178).

O problema dessas posições críticas é que esses estudiosos não conseguiram desvincular o radicalismo das experiências de Murilo nesse livro de um mero experimentalismo gratuito e pueril já que não viram que as originais associações verbais realizadas pelo poeta correspondiam a "respostas dramáticas de uma consciência cosmogônica" (ARAÚJO, 2000, p. 130). Sobretudo, não souberam distinguir que a síntese alcançada por Murilo em CV é original "mas também antiga, se a encararmos como conseqüência de sua indesviável opção poética." (ARAÚJO, 2000, p. 134). 


\section{CONCLUSÃO}

Nossa consideração da poesia de Murilo Mendes teve como ponto de partida o exame aprofundado, na medida do possível, da recepção crítica de sua obra e de algumas questões polêmicas presentes no seu interior. Assim, num primeiro momento constatamos a existência de duas tendências críticas com perspectivas diferentes em relação à poesia muriliana e fizemos o mapeamento de seus pontos de vistas, realizando um contraste entre eles a fim de verificar a validez de suas considerações.

Em nossa discussão acerca da recepção crítica exploramos uma questão extremamente controversa verificada no interior da primeira tendência, qual seja, o estabelecimento de uma divisão da poesia muriliana em fases qualitativas. Este fato, a divisão de uma obra em fases, é um recurso didático e metodológico muito comum na crítica literária, porém revelou-se, no que tange à obra de Murilo, um procedimento tendencioso e revelador de um duplo preconceito de certa parte de nossa crítica literária brasileira. Tal segmento da crítica desprivilegia e desclassifica dois dos elementos mais importantes e, por que não dizer, essenciais da poesia de Murilo: sua religiosidade e a presença do surrealismo.

Isso ocorre porque a primeira tendência crítica valoriza, sobremaneira, o elemento do rigor em sua poesia em detrimento dos dois elementos já citados. Basicamente, a ideia implícita contida nessa perspectiva é a de que Murilo teria, em sua "segunda fase", eleita como a superior por essa tendência, atenuado seus excessos anteriores e atingido um maior aperfeiçoamento formal. É Murilo Marcondes de Moura (1995) quem resume de modo decisivo essa situação:

\footnotetext{
o que parece muito claro é que dois preconceitos básicos deram-se as mãos diante da poesia de Murilo Mendes (e ainda persistem em larga medida): um no plano da realização artística, outro em relação ao seu pensamento religioso. Simplificando: procedimentos próximos do surrealismo e visão de mundo informada pelo cristianismo. Nada mais, nada menos que os dois aspectos nucleares de sua poética (...). Mas raramente houve preocupação em localizá-los de modo particular na obra do poeta. O mínimo de esforço, porém, já teria sido suficiente para perceber desde os anos 20 a dimensão de rigor, para os que prezam tanto, no projeto de Murilo Mendes; inclusive em termos próximos aos que a crítica posterior a 1959 formulou. (MOURA, 1995, p. 58)
}

Ainda segundo Moura, se o que a crítica chamou de "irregularidade formal" da poesia de Murilo é discutível, o que passou a se chamar de "rigor", pelo menos no 
sentido que lhe atribuem os movimentos artísticos dos anos 50-60 e - embora o crítico não mencione, sabemos que se refere, sobretudo, ao concretismo -, também o é. Dessa maneira, pudemos concluir que essa divisão qualitativa consiste num elogio ao construtivismo numa clara demonstração da existência de uma espécie de controle institucional da interpretação presente na crítica literária, como indicamos em nosso primeiro capítulo demarcando a que concepções estético-ideológicas estes críticos estavam fundamentados.

Outro fato interessante é que os críticos representantes desta tendência, quais sejam Alfredo Bosi, Haroldo de Campos, João Alexandre Barbosa e Luiz Costa Lima, embora convirjam num primeiro momento, apresentam opiniões divergentes no que tange a algumas questões concernentes à poesia muriliana, como, por exemplo, a eleição do livro considerado por cada um eles como o ápice de sua trajetória poética. Neste ponto, cada um elegeu um livro diferente para demarcar esse momento como vimos em nosso capítulo inicial.

De resto, essa manifestação da crítica acompanha de perto algo que ocorreu com a própria linguagem da poesia moderna que, como observou muito bem Alfonso Berardinelli (2007), oscilou de um extremo total de liberdade e hasard a um voluntarismo construtivista e à utopia de um controle absoluto do processo criativo e dos efeitos sobre o leitor ${ }^{139}$.

Por outro lado, a segunda tendência crítica, cuja perspectiva também foi analisada e devidamente apropriada por nós neste trabalho, manifesta a impossibilidade dessa divisão qualitativa rígida. Para estes críticos, também é inegável que a poesia de Murilo atingiu ao longo de sua trajetória uma maior condensação da linguagem poética devido ao fato de que o senso e o rigor construtivos foram elementos que o poeta jamais negligenciou. Contudo, como observa Murilo Marcondes de Moura (1995), o poeta nunca adotaria inteiramente a noção do rigor formal como valor último e superior, pois "para quem exigia tanto da poesia, esse era um projeto restritivo demais, e comparativamente muito pobre" (p. 59).

Para esta tendência crítica, a divisão qualitativa em fases efetuada pela primeira tendência é algo arbitrário e inconsistente e apontaria para o beneficiamento de certo tipo de poesia, como já vimos. Sobretudo aqueles dois elementos nucleares da obra muriliana, o surrealismo e o catolicismo, vistos pela primeira tendência como nocivos à

\footnotetext{
${ }^{139}$ Essa racionalização do processo compositivo de poesia tem seu protótipo teórico representado, para Berardinelli, no texto "Filosofia da composição", de Edgar Allan Poe.
} 
qualidade de sua poesia, são considerados por estes críticos como referenciais que sustentaram tanto o projeto estético quanto ético muriliano. Desse modo, para esta segunda tendência, as ditas "fases" murilianas não devem ser vistas como momentos isolados e excludentes no interior da trajetória do poeta, já que é possível traçar um raio de referenciais, certa estética de base, como indicou Sebastião Uchôa Leite (2003), que acompanhou Murilo do início ao fim de sua produção poética.

Nosso trabalho se identificou com e assumiu a perspectiva desta segunda tendência crítica, principalmente no que se refere a ideia de que pode ser identificada, ainda que com certas mudanças, a presença de certos vetores temático-formais característicos e orientadores da poesia de Murilo desde seus livros iniciais até o seu último livro lançado em vida. Foi com o intuito de verificar esta hipótese que apontamos e analisamos a presença desses vetores no último livro de Murilo em nosso terceiro capítulo, com base, sobretudo, na perspectiva postulada por Sebastião Uchôa Leite (2003) da existência de um "diálogo intertextual" presente na obra muriliana como um todo.

A análise deste livro, em especial, e da recepção crítica de Murilo nos possibilitou, também, a discussão e a retomada de algumas questões que circundam não só a sua poesia, mas também a própria poesia moderna em geral, como, dentre outras, o debate existente de uma tensão na poesia moderna entre uma poesia de expressão e uma poesia de construção; a questão da experimentação poética e a autorreflexividade poética.

A consideração de Convergência nos permitiu flagrar um movimento próprio da poesia de Murilo: uma metamorfose contínua, porém com a permanência de certos elementos dos quais o poeta nunca se distanciou. É possível notar que houve sim mudanças na poesia de Murilo, de resto, algo comum e normal na trajetória de qualquer artista, mas essas mudanças não expurgaram de sua obra seus elementos e atributos característicos. Esse movimento próprio de sua poesia, mudança com permanência, torna a sua obra "proteiforme", como observou Joana Matos Frias (2002), proporcionou ao poeta construir uma obra heterogênea e convergente, na medida em que preservou, aliadas à sua capacidade de renovação e transformação, certas características e direções que permaneceram, embora com evidentes transformações, até o fim de sua trajetória.

Deste modo, a leitura do último volume de poemas de Murilo demonstra que, embora o poeta tenha percorrido diversos caminhos e ainda que tenha havido algumas 
mudanças em sua obra ao longo do tempo, estas tampouco foram incompatíveis com certa unidade de sua obra. Em Convergência, Murilo nos apresenta um resumo de sua bildung poético-intelectual. Seus poemas resgatam um espaço de sociabilidade, de leitura e criação comprovando que a poesia, para ele, parece ter sido sempre vivida e considerada como uma experiência da multiplicidade.

Murilo empreendeu desde o início de sua produção poética o desafio de compreender a própria pluralidade e totalidade da vida e do homem. Para isso, o poeta teve que encontrar uma forma e uma expressão/voz múltiplas que dessem conta de responder, ou ao menos percorrer, essa pluralidade sem impor um sentido único e limitador.

Deste modo, sua obra não estaria tão distante, embora guardadas algumas ressalvas e diferenças, da perspectiva postulada e analisada por Edward W. Said (2009) em Estilo Tardio. Neste livro ${ }^{140}$, o crítico analisou as obras finais de alguns artistas nas quais, ao invés de serenidade e unidade, encontramos, ao contrário, obras avessas a uma conciliação e a um provável fechamento. Estas obras traduziriam "a experiência de um estilo tardio que tem a ver com uma tensão despida de harmonia ou serenidade, com uma produtividade conscientemente improdutiva, do contra..." (SAID, 2009, p. 27).

Ao analisar a obra de artistas como Beethoven, Mozart, Jean Genet e Thomas Mann, Said demonstra como a consciência aguda de um fim eminente resultou não numa resignação perante a morte, mas sim em obras finais irregulares e difíceis nas quais encontramos, ao invés de uma resolução, "intransigência, dificuldade e contradição em aberto" (SAID, 2009, p. 27). Esses artistas subverteram e instauraram uma dissonância, um rompimento com a própria trajetória, abandonando e rompendo com convenções de seu tempo e/ou suas próprias convicções ou orientações artísticas anteriores. Estas obras tardias apresentam-se, então, nessa perspectiva, como um gesto de recusa a uma autossatisfação e ao alcance de uma maturidade estética presumível. Said chega mesmo a afirmar que estas obras irreconciliáveis, ao traduzir uma impossibilidade total de síntese, constituiriam uma espécie de exílio: "ser tardio é

\footnotetext{
${ }^{140}$ Edward Said toma emprestado o conceito de "estilo tardio" ao filósofo Theodor Adorno, que em seu ensaio "O estilo tardio de Beethoven", de 1937, analisou as obras do que é considerado o terceiro período de composição de Beethoven, as cinco últimas sonatas para piano, os seis últimos quartetos, a Missa solemnis e a Nona sinfonia, a fim de demonstrar como o compositor teria alcançado um grau de elevação estética em relação a seu tempo, criando peças musicais que desafiaram o público e os padrões de julgamento da crítica artística da época.
} 
portanto uma espécie de exílio autoimposto diante de tudo o que costuma ser aceito, um exílio posterior e sobrevivente a isso" (SAID, 2009, p. 36).

Embora em Convergência, como pudemos notar, Murilo realize uma reunião de todo o seu itinerário na medida em que se percebem, neste livro, alguns dos temas orientadores de sua poesia, nota-se que, ao final, aquela sua busca pela totalidade foi uma busca inconclusa, irrealizada. Assim, mesmo ao final de sua trajetória, Murilo continua na busca desta totalidade ainda que seu resultado seja ambivalente, posto que ela "ora se apresenta como auto-satisfeita, ora como impossível" (MOURA, 1995, p. 192).

Assim, sua obra representa a busca por uma totalização que nunca se completou, marcada por certas inquietudes e um permanente conflito com a realidade que, mesmo nos últimos livros, persistirá. Daí que alguns críticos indiquem certa melancolia e angú stia $^{141}$ presente em sua obra tardia, certo desencantamento quanto à possibilidade da literatura e a arte poderem interferir num mundo cada vez mais marcado pelo progresso técnico e pela massificação da cultura. O fato é que, desencantado ou não, o poeta persistiu e resistiu utilizando e jogando com as suas armas de sempre, certos temas, preocupações e procedimentos que sempre circundaram sua poesia.

Com Convergência, Murilo fecha sua obra poética indicando que em seu fim está o seu começo e vice-versa. A propósito, não parece mera citação impensada a inclusão de um verso de T. S. Eliot no poema-mensagem que Murilo lhe dedica, "Murilograma a T. S. Elliot", um verso sintomático que resume, assim, a própria trajetória dessa poesia em contínua "autoinvenção e metamorfose":

NO MEU PRINCÍPIO ESTÁ MEU FIM.

Os tempos se sucedem se acavalam, engrenagem.

Se autoesfregando, se roendo, se recriando

Em contínua autoinvenção \& metamorfose. (...)

IN MY BEGINNING IS MY END. ${ }^{142}$

\footnotetext{
${ }^{141}$ Isso é apontado por Luciana Stegagno-Picchio em relação a Ipotesi, livro de poemas escrito em italiano e publicado postumamente, em 1977, na Itália. Em introdução ao livro, Luciana comenta sobre a angústia que dominava o poeta frente à eminência da morte, verdadeira protagonista do livro, segundo Luciana: "Em Roma, ao lado do poeta instala-se a morte-angústia. Ela foi a última condição do amigo que nós recordamos, o Murilo pálido, de olhos ardentes, ao qual, a quem lhe perguntava do como e o porquê, podia só responder 'angústia'. A morte pressentida de quem está já no limite e quer, mas não pode, esperar sereno, apartado e apaziguado a aparição do véu de Maia.” Luciana Stegagno-Picchio, PCP, p. 1709.

${ }^{142}$ PCP, p.697-698.
} 
Percebemos que, desde o início de sua trajetória, Murilo sempre mostrou-se possuidor de uma força poética com tal sentido revolucionário, que por si só já lhe garante um lugar especial, de inovação e singularidade, no panorama da poesia brasileira. O poeta edificou uma obra dialeticamente simples e complexa, "entre as colunas da ordem e da desordem"; e tal percurso só foi possível devido à própria postura estética muriliana vinculada à extrema noção de liberdade e independência criativa conquistada pelos escritores e poetas modernos. Assim sendo, a obra poética muriliana assumiu um caráter de transformação e metamorfose permanentes angariando sempre novas referências sem, no entanto, negar ou abandonar as anteriores. Desta forma, ao final de sua produção, o poeta pôde evidenciar a convergência de sua poesia demonstrando a importância de sua obra, que desde sua gênese sempre esteve aberta a diversas possibilidades e meios de manifestação do poético.

Por isso, pensamos que querer delimitar e circunscrever a poesia de Murilo Mendes a escolas/movimentos/teorias é ignorar-lhe a própria amplitude e intensidade. Acima das classificações unilaterais que tendem a fechar sua obra reforçando-lhe ora o seu caráter construtivista, ora o influxo surrealista e religioso de sua poesia, cremos que sua poesia deva ser considerada e discutida no mesmo nível de igualdade de qualquer outra obra de valor estético.

Esperamos não ter incorrido neste equívoco de fechar rigidamente nossa leitura de sua obra e, por conseguinte, também, a de sua recepção crítica. Nossa pesquisa procurou apresentar uma perspectiva acerca da recepção e da poesia de Murilo, visão sobre a qual, de resto, ainda estamos a e continuaremos a refletir. Portanto, deixamos aberta, aqui, a possibilidade efetiva de desdobramentos futuros para esta pesquisa e, por outro lado, assumimos, desde já, o risco inerente à atividade crítica, pois temos consciência de que uma das peculiaridades do texto literário e dos objetos estéticos, em geral, é a sua inesgotabilidade de leitura. Essa capacidade de suscitar e sustentar novas interpretações mantém-se com o passar do tempo, ao contrário dos simples produtos culturais reservados ao entretenimento fácil e destinados a uma obsolescência programada. Neste sentido, que a própria poesia de Murilo possa nos servir de juíza, pois como afirma o poeta num aforismo de O Discípulo de Emaús: "Sempre, em todos os tempos a poesia corrigiu a crítica" ${ }^{143}$. E que assim continue sendo. Sempre.

${ }^{143}$ PCP, p. 872 (aforismo n ${ }^{\circ} 567$ ). 


\section{Referências}

ADORNO, Theodor. Notas de Literatura. Rio de Janeiro: Tempo Brasileiro, 1973.

ANDRADE, Carlos Drummond de. O observador no escritório: páginas de diário. Rio de Janeiro: Record, 1985.

ANDRADE, Carlos Drummond de. Poesia Completa. Rio de Janeiro: Ed. Nova Aguilar, 2002.

ANDRADE, Mário de. Aspectos da Literatura Brasileira. São Paulo: Martins, 1978.

ARAÚJO, Laís Corrêa de. Murilo Mendes - Ensaio Crítico, Antologia e Correspondência. São Paulo: Perspectiva, 2000.

ARAÚJO, Laís Corrêa de. "Murilo Mendes e a fase histórica do Modernismo". Revista de Cultura Vozes. Rio de Janeiro: Vozes. Vol. LXVI. Ano 66. Janeiro/Fevereiro, 1972, p.47-52.

ARRIGUCCI JÚNIOR, Davi. O Cacto e as Ruínas. A Poesia entre Outras Artes, São Paulo: Ed. Duas Cidades, 1997.

ARRIGUCCI JÚNIOR, Davi. Coração Partido - Uma análise da poesia reflexiva de Drummond. São Paulo: Cosac \& Naify, 2002.

BAKHTIN, Mikhail. A cultura popular na Idade Média e no Renascimento: o contexto de François Rabelais. São Paulo: Editora Hucitec, 1987.

BARBOSA, João Alexandre. A metáfora crítica. São Paulo: Ed. Perspectiva, 1974.

BARBOSA, João Alexandre. A tradição do impasse: linguagem da crítica e crítica da linguagem em José Veríssimo. São Paulo: Ática, 1974.

BARBOSA, João Alexandre. As ilusões da modernidade: notas sobre a historicidade da lírica moderna. São Paulo: Editora Perspectiva, 1986. 
BARBOSA, João Alexandre. A Imitação da forma: uma leitura de João Cabral de Melo Neto. São Paulo: Duas Cidades, 1975.

BERARDINELLI, Alfonso. Da poesia à prosa. São Paulo: Cosac Naify, 2007.

BLANCHOT, Maurice. A parte do fogo. Trad. Ana Maria Scherer. Rio de Janeiro:

Rocco, 1997.

BOSI, Alfredo. História Concisa da Literatura Brasileira. 43ª ed. São Paulo: Cultrix, 2004.

CALVINO, Italo. Seis propostas para o próximo milênio: lições americanas. São Paulo: Companhia das Letras, 1990.

CALVINO, Italo. "Traduzir é o verdadeiro modo de ler um texto." Trad. Andréia Guerini e Tânia Mara Moysés. Suplemento Literário de Minas Gerais. Belo Horizonte: Imprensa Oficial do Estado de Minas Gerais, março/abril/2011.

CAMPOS, Haroldo de. Metalinguagem e Outras Metas. São Paulo: Perspectiva, 1970.

CAMPOS, Haroldo de. O sequestro do Barroco na formação da literatura brasileira: o caso Gregório de Matos. Salvador: Fundação Casa Jorge Amado, 1989.

CAMPOS, Haroldo de. "Os poetas concretos e João Cabral de Melo Neto: um testemunho". In: COLÓQUIO LETRAS, n 157/158. Lisboa: Fundação Calouste Gulbekian, julho-dezembro de 2000, p.27-31.

CANDIDO, Antonio. Literatura e Sociedade. São Paulo: Cia. Ed. Nacional, 1976.

CANDIDO, Antonio. Vários Escritos. São Paulo: Livraria Duas Cidades, 1977.

CANDIDO, Antonio. Formação da literatura brasileira. 6. ed. Belo Horizonte: Itatiaia, 1981. $2 \mathrm{v}$.

CANDIDO, Antonio. A Educação pela noite. São Paulo: Editora Ática, 1989.

CANDIDO, Antonio. Iniciação a Literatura Brasileira. São Paulo: Humanitas Publicações - FFLCH/USP, 1999. 
CAVALCANTI FILHO, José Paulo. Fernando Pessoa: uma quase autobiografia. Rio de Janeiro: Record, 2011.

CHKLOVSKI, Victor. "A arte como procedimento". Teoria da Literatura - Os formalistas russos. $4^{\mathrm{a}}$ ed. Porto Alegre: Ed. Globo, 1978.

COMPAGNON, Antoine. O trabalho da citação. Trad. Cleonice P. B. Mourão. Belo Horizonte: Editora UFMG, 1996.

DAIBERT, Arlindo. Caderno de escritos. Org. Júlio Castañon Guimarães. Rio de Janeiro: Sette Letras, 1995.

ELIOT, T. S. Ensaios de Doutrina Crítica. Trad. Fernando de Mello Moser. Lisboa: Guimarães Editores, 1997.

FRANCO, Irene Miranda. Murilo Mendes: pânico e flor. Rio de Janeiro: Sette Letras; Juiz de Fora: Centro de Estudos Murilo Mendes - UFJF, 2002.

FRIAS, Joana Matos. "Murilo Mendes e o cosmotexto ideogramático”. Porto: Línguas e Literaturas, Revista da Faculdade de Letras, XVI, 1999, p.125-142.

FRIAS, Joana Matos. O Erro de Hamlet: poesia e dialética em Murilo Mendes. . Rio de Janeiro: Sette Letras; Juiz de Fora: Centro de Estudos Murilo Mendes - UFJF, 2002. FRIEDRICH, Hugo. Estrutura da Lírica Moderna. São Paulo: Duas Cidades, 1978.

GUIMARÃES, Júlio Castañon. Territórios/Conjunções. Poesia e Prosa Crítica de Murilo Mendes, Rio de Janeiro: Imago, 1993.

GUIMARÃES, Júlio Castañon. Prefácio a Tempo Espanhol. In: MENDES, Murilo. Tempo Espanhol. Rio de Janeiro: Record, 2001.

GULLAR, Ferreira. Sobre arte Sobre poesia (uma luz no chão). 2a ed. Rio de Janeiro: José Olympio, 2006.

JAUSS, Hans Robert. A História da Literatura Como Provocação à Teoria Literária. São Paulo: Ática, 1994. 
KAHN, Charles H. A arte e o pensamento de Heráclito: uma edição dos fragmentos com tradução e comentário. Org. Charles H. Kahn. Trad. Élcio Gusmão Verçosa Filho. São Paulo: Paulus, 2009.

KAFKA, Franz. O processo. Trad. Modesto Carone. São Paulo: Companhia das Letras, 2005

KERMODE, Frank. Um Apetite pela Poesia: ensaios de interpretação literária. Trad. Sebastião Uchôa Leite. São Paulo: Editora da Universidade de São Paulo, 1993.

LAFETÁ. João Luiz. 1930: A Crítica e o Modernismo. São Paulo: Duas Cidades; Ed. $34,2000$.

LEITE, Sebastião Uchôa. Crítica de ouvido. São Paulo: Cosac e Naify, 2003, p.61-72.

LIMA, Luiz Costa. Teoria da literatura em suas fontes. Vol. II. $2^{\mathrm{a}}$ Ed. Org. Luiz Costa Lima. Rio de Janeiro: Francisco Alves, 1975.

LIMA, Luiz Costa. Intervenções. São Paulo: Edusp, 2002.

LIMA, Sérgio. A Aventura Surrealista. São Paulo: Editora Vozes/Unesp/Unicamp, 1995

LOPES, Teresa Rita. Pessoa por Conhecer, as dramatis personae. Lisboa: Estampa, 1990, vol.I.

MARTINS, Floriano. O começo da busca: o surrealismo na poesia da América Latina. São Paulo: Escrituras Editora, 2001.

MARTINS, Wilson. Pontos de vista: crítica literária. São Paulo: T. A. Queiroz, 1991.

MENDES, Murilo. História do Brasil. Rio de Janeiro: Nova Fronteira, 1991.

MENDES, Murilo. Poesia Completa e Prosa. Rio de Janeiro: Nova Aguilar, 1994.

MENDES, Murilo. Formação da discoteca. São Paulo: Giordano; Loyola; Edusp, 1993.

MERQUIOR, José Guilherme. "À Beira do Antiuniverso Debruçado". O Fantasma Romântico e outros ensaios. Rio de Janeiro: Vozes, 1980, p.151-160. 
MERQUIOR, José Guilherme. A astúcia da mimese: ensaios sobre lírica. Rio de Janeiro: José Olympio, 1972.

MERQUIOR, José Guilherme. Verso universo em Drummond. Rio de Janeiro: Livraria José Olympio, 1975.

MERQUIOR, José Guilherme. "Murilo Mendes ou a poética do visionário”. Razão do Poema. Rio de Janeiro: Topbook, 1996, p.51-68.

MERQUIOR, José Guilherme. Notas para uma Muriloscopia. In Murilo Mendes. Poesia Completa e Prosa. Rio de Janeiro: Nova Aguilar, 1994, p.11-21.

MOURA, Murilo Marcondes de. A Poesia como Totalidade. São Paulo: Edusp, 1995.

MOURA, Murilo Marcondes de. "Os jasmins da palavra jamais". Leitura de Poesia. Org. BOSI, Alfredo. São Paulo: Ática, 2001.

NADEAU, Maurice. História do Surrealismo. São Paulo: Perspectiva, 1985.

NEVES, Daniela. Murilo Mendes: o poeta das metamorfoses. Belo Horizonte: PUC Minas, 2001.

NUNES, Benedito. "Estética e correntes do Modernismo". In: O Modernismo. Org. ÁVILLA, Affonso. São Paulo: Perspectiva, 1975, 39-53.

PAES, José Paulo. Os perigos da poesia e outros ensaios. Rio de Janeiro: Topbooks, 1997.

PAZ, Octavio. Signos em Rotação. São Paulo: Perspectiva, 1972.

PAZ, Octavio. O Arco e a lira. $2^{\mathrm{a}}$ ed. Trad. Olga Savary. Rio de Janeiro: Nova Fronteira, 1982.

PAZ, Octavio. Os filhos do barro: do romantismo à vanguarda. Trad. Olga Savary. Rio de Janeiro: Nova Fronteira, 1984.

PAZ, Octavio. Los Hijos del Limo - Del Romanticismo a La Vanguardia. Barcelona: Seix Barral, 1993. 
PAZ, Octavio. A outra voz. Trad. Wladir Dupont. São Paulo: Siciliano, 1993.

PERRONE-MOISÉS, Leyla. Altas Literaturas: escolha e valor na obra crítica de escritores modernos. São Paulo: Companhia das Letras, 1998.

PONGE, Robert. Surrealismo e novo mundo. Org. Robert Ponge. Porto Alegre: Editora UFRGS, 1999.

PONGE, Robert. Aspectos do Surrealismo. Organon. $\mathrm{n}^{\mathrm{o}}$ 22. Porto Alegre: Instituto de Letras da UFRGS, 1994.

RAYMOND, Marcel. De Baudelaire ao Surrealismo. Trad. Fúlvia M. L. Moretto, Guacira Marcondes Machado. São Paulo: Editora Universidade de São Paulo, 1997.

SAID, Edward W. Estilo tardio. Tad. Samuel Titan Jr.. São Paulo: Companhia das Letras, 2009.

SCHWARTZ, Jorge. Vanguardas latino-americana. Polêmicas, manifestos e textos críticos. São Paulo: Editora Iluminuras/Edusp/Fapesp, 1995.

SCHNAIDERMAN, Boris. "Bakhtin, Murilo, prosa/ poesia”. Estudos Avançados. Vol. 12, no 32. São Paulo: Edusp, 1998, p. 75-81.

SPTIZER, Leo. La enumeración caótica em la poesía moderna. Madrid: Editorial Gredos, 1955.

STEGAGNO PICCHIO, Luciana. "Pequena História da História do Brasil de Murilo Mendes”. In: MENDES, Murilo. Rio de Janeiro: Nova Fronteira, 1991, p.5-7.

STEGAGNO PICCHIO, Luciana. "Itinerário poético de Murilo Mendes". Revista do livro. Rio de Janeiro: INL, ano 4, nº16, p.36-52.

TRAGTENBERG, Livio. Artigos Musicais. São Paulo: Perspectiva, 1991.

TOLENTINO, Bruno. Os sapos de ontem. Rio de Janeiro, Diadorim, 1995. 